\title{
ON THE STRUCTURE
}

of

\section{GREEK TRIBAL SOCIETY}

\author{
$A N \quad E S S A Y$
}

ssis.

Zlonion

MACMILLAN AND CO.

AND NEW YORK

1895 


\section{PREFACE}

THese notes, brief as they are, owe more than can be told to my father's researches into the structure and methods of the Tribal System. They owe their existence to his inspiration and encouragement. A suitable place for them might possibly be found in an Appendix to his recently published volume on the Structure of the Tribal System in Wales.

In ascribing to the structure of Athenian Society a direct parentage amongst tribal institutions, I am dealing with a subject which I feel to be open to considerable criticism. And I am anxious that the matters considered in this essay should be judged on their own merits, even though, in pursuing the method adopted herein, I may have quite inadequately laid the case before the reader.

My thanks are due, for their ready help, to Professor W. Ridgeway, Mr. James W. Headlam, and Mr. Henry Lee Warner, by means of whose kind suggestions the following pages have been weeded of several of their faults.

It is impossible to say how much I have consciously or unconsciously absorbed from the works 
of the late M. Fustel de Coulanges. His La Cité Antique and his Nouvelles Recherches sur quelques Problèmes d'Histoire (1891) are stores of suggestive material for the student of Greek and Roman customs. They are rendered all the more instructive by the charm of his style and method. I have merely dipped a bucket into his well.

In quoting from Homer, I have made free use of the translations of Messrs. Lang, Leaf, and Myers of the Iliad, and of Messrs. Butcher and Lang of the Odyssey; and I wish to make full acknowledgment here of the debt that I owe to them.

Some explanation seems to be needful of the method pursued in this essay with regard to the comparison of Greek customs with those of other countries. The selection for comparison has been entirely arbitrary.

Wales has been chosen to bear the brunt of illustration, partly, as I have said, because of my father's work on the Welsh Tribal System, partly because the Ancient Laws of Wales afford a peculiarly vivid glimpse into the inner organisation of a tribal people, such as cannot be obtained elsewhere.

The Ordinances of Manu, on the other hand, are constantly quoted by writers on Greek institutions; and, I suppose, in spite of the uncertainty of their date, they can be taken as affording a very fair account of the customs of a highly developed Eastern people. It would be hard, moreover, to say where the connection of the Greeks with the East began or ended.

The use made of the Old Testament in these notes hardly needs further remark. Of no people, in their true tribal condition before their settlement, have we a more graphic account than of the Israelites. Their proximity geographically to the Phœnicians, and the accounts of the widespread fame of Solomon and the range of his commerce, at once suggest comparison with the parallel and contemporaneous period of Achaian history, immediately preceding the Dorian invasion, when, if we may trust the accounts of Homer, the intercourse between the shores of the Mediterranean must have been considerable.

All reference to records of Roman customs has been omitted, not because they are not related or analogous to the Greek, but because they could not reasonably be brought within the scope of this essay. The ancestor-worship among the Romans was so complete, and the organisation of their kindreds so highly developed, that they deserve treatment on their own basis, and are sufficient to form the subject of a separate volume.

\footnotetext{
The Hermitage, Hitchin. July, 1895
}

H. E. S. 


\section{CONTENTS}

\section{CHAPTER I.}

INTRODUCTORY . . . . . . . . . .

\section{CHAPTER II.}

THE MEANING OF THE BOND OF KINSHIP.

§ 1. The DUTY of Maintenance of PaRents DURING Life, AND AFTER DEATH AT THEIR TOMB . . . . .

§ 2. THE DUTY OF PROVIDING MALE SUCCESSION . . . .

§ 3. THE POSITION OF THE WIDOW WITHOUT CHILD AND THE DUTIES OF AN ONLY DAUGHTER

§ 4. SUCCESSION THROUGH A MARRIED DAUGHTER : GROWTH OF ADOPTION: INTRODUCTION OF NEW MEMBER TO KINSMEN

§ 5. THE LIABILITY FOR BLOODSHED . . . . . . . . . 4 


\section{CHAPTER III.}

THE EXTENT OF THE BOND OF KINSHIP.

§ 1. DEGREES OF BLOOD RELATIONSHIP; THE ATXI乏TEIA .

\$ 2. LIMITATIONS IN RESPECT OF SUCCESSION OUTSIDE THE DIRECT LINE OF DESCENT . . . . . . . . . 56

§ 3. DIVISION AMONGST HEIRS . . . . . . . . . . . . 64

\$ 4. QUALIFICATION FOR THE RECOGNITION OF TRIBAL BLOOD 67

§ 5. LIMITATIONS OF LIABILITY FOR BLOODSHED . . . . . 75

CHAPTER IV.

THE RELATION OF THE FAMILY TO THE LAND.

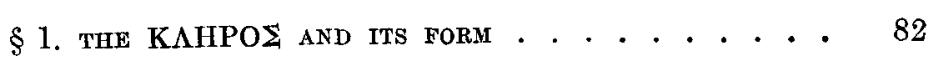

§ 2. THE RELATION OF THE KAHPO乏 TO THE OIKO . 88

§ 3. THE HOUSEHOLDER IN INDIA : THE GUEST . . . . . 97

§ 4. TENURE OF LAND IN HOMER: THE KAHPO乏 AND THE TEMENOS .............. . 102

§ 5. EARLY EVIDENCE continued: THE KAHPOS AND THE MAINTENANCE OF THE OIKOS . . . . . . . . 108

§ 6. EARLY EVIDENCE continued: THE TEMENOS AND THE MatNTENance of THE Chieftain . . . . . . 114
\& 7. SUMMARY OF THE EARLY EVIDENCE

§ 8. HESIOD AND HIS KNHPOS . . . . . . . . . . 123

§ 9. SURVIVALS OF FAMILY LAND IN LATER TIMES . . . . 124

§ 10. THE IDEA OF FAMILY LAND APPLIED ALSO TO LEASEHOLD AND SEMI-SERVILE TENURE . . . . . . . 129

CHAPTER V.

CONCLUSION . . . . . . . . . . . 137 


\section{CHAPTER I.}

\section{INTRODUCTORY.}

Is trying to ascertain the course of social develop- Cнap. I. ment among the Greeks, the inquirer is met by an vitality of initial difficulty. The Greeks were not one great the triba people like the Israelites, migrating into and settling system. in a new country, flowing with milk and honey. Their movements were erratic and various, and took place at very different times. Several partial migrations are described in Homer, and others are referred to as having taken place only a few generations back. The continuation of unsettled life must have had the effect of giving cohesion to the individual sections into which the Greeks were divided, in proportion as the process of settlement was protracted and difficult.

But in spite of divergencies caused by natural surroundings, by the hostility or subservience of previous occupants of the soil, there are some features of the tribal system, wherever it is examined, so inherent in its structure as to seem almost indelible. A new civilisation was not formed to fit into the angles of city walls. Even modification could take place 
Cuap. I. only of those customs whose roots did not strike too deeply into the essence of the composition of tribal society.

Its sur. It is the object of these notes to try to put back vivals in their true setting some of the conditions prevailing, subject of sometimes incongruously with city life, among the this in- Greeks in historical times, and by comparison with quiry. analogous survivals in known tribal communities, of whose condition we have fuller records, to establish their real historical continuity from an earlier stage of habit and belief.

The There were three important public places necessary Tolitical to every Greek community and symbolical to the and tribal Greek mind of the very foundations of their institusociety. tions. These were :- the Agora or place of assembly, the place of justice, and the place of religious sacrifice. From these three sacred precincts the man who stirred up civil strife, who was at war with his own people, cut himself off. Such an one is described in Homer as being, by his very act, 'clanless' (a' $\phi \rho$ ' $\tau \omega \rho)$, 'out-

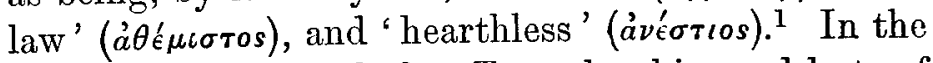
camp of the Greeks before Troy the ships and huts of his followers were congregated by the hut of their chief or leader. Each sacrificed or poured libation to his favourite or familiar god at his own hut door. ${ }^{2}$ But in front of Odysseus' ships, which, we are told, were drawn up at the very centre of the camp, stood the great altar of Zeus Panomphaios-lord of all oracles-'exceeding fair.' ${ }^{3}$ 'Here,' says the poet, ' were Agora, Themis, and the altars of the gods.'
1 Il. ix. 63 .
2 1l. ii. 400.
3 Il. xi. 807.

The Prytaneum and the Chieftain.

The Trojans held agora at Priam's doors, ${ }^{1}$ and it Crap. I. is noticeable that the space in front of the chief's hut or palace was generally considered available for such purposes as assembly, games, and so forth, just as it was with the ancient Irish.

In the centre of most towns of Greece ${ }^{2}$ stood the The PryPrytaneum or magistrates' hall, and in the Prytaneum and was the sacred hearth to which attached such rever- Hestia. ence that in the most solemn oaths the name of Hestia was invoked even before that of Zeus. ${ }^{3}$ Thucydides states that each $\kappa \omega \dot{\mu} \mu$ or village of Attica had its hearth or Prytaneum of its own, but looked up to the Hestia and Prytaneum in the city of Athens as the great centre of their larger polity. In just the same way the lesser kindreds of a tribe would have their sacred hearths and rites, but would look to the hearth and person of their chief as symbolical of their tribal unity. Thucydides also mentions how great a wrench it seemed to the Athenians to be compelled to leave their 'sacred' homes, to take refuge within the walls of Athens from the impending invasion by the Spartans.

The word Prytanis means 'chieftain.' It is probable that, as the duties sacred and magisterial of the chief became disseminated among the other officers of later civilisation, the chief's dwelling, called the

1 Il. ii. 788 .

2 Joumal of Philology, xiv. 145 (1885), Mr. Frazer on Prytaneum.

${ }^{3}$ Cauer, Delect. Inscr. Graec. $\$$ 121. (Crete, c. 200 B.c.) 'I swear by Hestia in the Prytaneum ( $\tau \dot{a} \nu \dot{\epsilon} \mu \pi \rho v \tau a \nu \in i \omega)$, by Zeus of the Agora, Zeus Tallaios, Apellon Delphinios, Athanaia Poliouchos,
Apellon Poitios, and Lato, and Artemis, and Ares, and Aphordite, and Hermes, and Halios .... and all gods and goddesses.' $C f$. also $\$ 116$, and Od. xiv. 158 . Plato, in Laws $\S 848$, says Hestia, Zeus and Athena shall have temples everywhere. 4 Thuc. ii. 16. 
Chap. I. Prytaneum, acquiring vitality from the indelible superstition attaching to the hearth within its precincts, maintained thereby its political importance, when nothing but certain religious functions remained to its lord and master in the office of Archon Basileus.

Their Mr. Frazer, in his article in the Journal of Philology ${ }^{1}$ upon the resemblance of the Prytaneum in Greece to the Temple of Vesta in Rome, shows that both had a direct connection with, if not an absolute origin in the domestic hearth of the chieftain. The Lares and Penates worshipped in the Temple of Vesta, he says, were originally the Lares and Penates of the king, and were worshipped at his hearth, the only difference between the hearth in the temple and the hearth in the king's house being the absence of the royal householder. ${ }^{2}$

Mr. Frazer also maintains that the reverence for the hearth and the concentration of such reverence on the hearth of the chieftain was the result of the difficulty of kindling a fire from rubbing sticks together, and of the responsibility thus devolving upon the chieftain unfailingly to provide fire for his people. Whether this was the origin or not, before the times that come within the scope of this inquiry, the hearth had acquired a real sanctity which had become involved in the larger idea of it as the centre of a kindred, including on occasion the mysterious presence also of long dead ancestors.

Qualifica- The basis of tribal coherence was community of $\substack{\text { tion for } \\ \text { share in }}$
blood, actual or supposed; the visible evidence of the

1 Journal of Philol. xiv. 145. | 2 Op. cit. p. 153. possession of tribal blood was the undisputed partici- CHAP. I. pation, as one of a kindred, in the common religious religious ceremonies, from which the blood-polluted and the rites one stranger-in-blood were so strictly shut out. ${ }^{1}$ It is therefore in the incidence of religious duties, and in the qualifications of the participants, that it is reasonable to seek survivals of true tribal sentiment.

Although the religious life of the Greeks was always complex, there is not to be found in Homer the broad distinction drawn afterwards between public and private gods. It is noticeable that the later Greeks sought to draw into their homes the beneficent influence of one or other of the greater gods, whose protection and guidance were claimed in times of need by all members of the household. Secondary influences, though none the less strongly felt, were those of the past heroes of the house, sometimes only just dead, to be propitiated at the family tombs or hearth. Anxiety on this head, and the deeply-rooted belief in the real need to the dead of attentions from the living, were, it will be seen, most powerful factors in the development of Greek society.

The worship of ancestors or household gods as Ancestorsuch is not evident in the visible religious exercises worship of the Homeric poems. But this can hardly be a obvious in matter of surprise. The Greek chieftains mentioned in the poems are so nearly descended from the gods themselves, are in such immediate relation each with his guardian deity, and are so indefatigable in their attentions thereto, that it would surely be

\footnotetext{
1 Exception, however, was | the stranger as a favoured guest, sometimes made in the case of $\mid \begin{aligned} & v \text {. infra, p. } 99 . \\ & \text {. }\end{aligned}$
} 
Crap. I. extremely irrelevant if any of the libations or hecatombs were perverted to any intermediate, however heroic, ancestor from the all-powerful and ever ready divinity who was so often also himself the boasted founder of the family. ${ }^{1}$

offerings The libations and hecatombs themselves, however, of food to
the gods, seem to serve much the same purpose as the offerings to the manes or household gods, and relieved the luxurious craving for sustenance in the immortals, left unsatisfied by their etherial diet of nectar and ambrosia. $^{2}$

and to the Yet it is strange that if libations and sacrifices were paid to the dead periodically at their tombs, no mention of the occurrence is to be found in Homer. That the dead were believed to appreciate such attentions may be gathered from the directions given by Circe to Odysseus.

'Then pour a drink-offering to all the dead, first with mead $(\mu \in \lambda \iota k \rho \dot{\eta} \tau \omega)$, and thereafter with sweet wine, and for the third time with water, and sprinkle white meal thereon .... and promise thou wilt offer in thy halls ${ }^{3}$ a barren heifer, the best thou hast, and fill the pyre with treasure, and wilt sacrifice apart to Teiresias alone a black sheep without spot, the fairest of your flock.'

The con- This done, the ghosts flock up to drink of the blood tinuance
of hisname of the victim. But the ghost of Elpenor, who met important his death at the house of Circe by falling from the as offerings roof in his drunken haste to join his already departed
of food.

1 Plato (Laws 948) remarks | sacrifice was held to be a feast at that at the time of Rhadamanthos which the choice portions were the belief in the existence of the devoured by the god by means of gods was a reasonable one, seeing the fire on his altar. Cf. p. 139, that at that time most men were sons of gods.

3 It was not therefore only at from $\pi$. i. 466 et seq. that the could benefit by such offerings. comrades, and who had therefore received no burial CHar. I. at their hands, demands no libations or sacrifices for the refreshment of his thirsty soul, but merely burial with tears and a barrow upon the shore of the gray sea, that his name may be remembered by men to come.

Nestor's son elsewhere is made to remark that one must not grudge the dead their meed of tears; for the times are so out of joint, "this is now the only due we pay to miserable men, to cut the hair and let the tear fall from the cheek.' 1

Is the right conclusion then that the Homeric Greeks did not sacrifice at the tombs of their fathers, and that the so-called ancestor-worship prevalent later was introduced or revived under their successors? Or is it that the aristocratic tone of the poet did not permit him to bear witness to the intercourse with any deity besides the one great family of Olympic gods, less venerable than a river or other personification of nature? ${ }^{2}$

There exists such close family relationship amongst Homer's gods, extended as it is also to most of his chieftains, that taking into account the conspicuous

\footnotetext{
1 Od. iv. 197. Cf. Il. xvi. tion comes upon him:-- Ay me, 455.

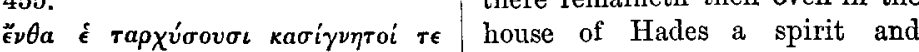
ÉTat T€ phantom of the dead, albeit the

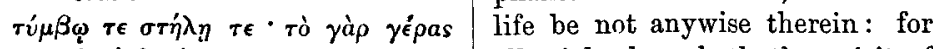

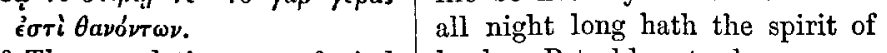
2 The speculative state of mind hapless Patroklos stood over me, displayed in the Iliad may be wailing and making moan, and illustrated from the effect on charged me everything that I Achilles of the apparition of should do, and wondrous like his Patroklos after death in a dream. living self it seemed.' $I l$. xxiii. As he wakes sudáenly the convic- 113 \&c.
} 
Cuap. I. reverence displayed towards the hearth and the respect for seniority in age, it may perhaps be justifiable to suppose that domestic religious observances, other than those directed to the Olympic gods, were thought by the poet to be as much beneath his notice as the swarms of common tribesmen who shrink and shudder in the background of the poems.

Offerings. Ancestor-worship would be as much out of place to the in in the Old Testament; and yet there are references the Old in the Bible to offerings to the dead which, unless they are held to refer only to importations from outside religions and not to relapses in the Israelites themselves to former superstitions of their own people, imply that the great tribal religion of the Israelites had superseded pre-existing ceremonies of ancestor-worship.

Dent. xxvi. 13. 'And thou shalt say before the Lord thy God, I have brought away the hallowed things out of mine house, and also have given them unto the Levite and the stranger, to the fatherless and to the widow, according to all thy commandments which thou hast commanded me: I have not transgressed thy commandments, neither have I forgotten them: I have not eaten thereof in my mourning, neither have I taken away ought thereof for any unclean use, nor given ought thereof for the dead.'

The transgressions of the Israelites in the wilderness are described in the Psalms:- 'They joined themselves also unto Baalpeor and ate the sacrifices of the dead.' 1

It was not necessary for an ancestor to become a god to be worthy of worship, or to need the attentions of the living. If he was thought to haunt tomb or hearth, and to keep his connection thus with his family in the upper world, he required nourishment on his visits. He was also considered

1 Ps. cvi. 28. v. Maine's Early Law and Custom, p. 59. to keep a jealous watch on the continuance of his Crap. I. fair fame among the living.

A close resemblance in this point lies between Resem the Homeric poems and the Old Testament. Though blance actual food and drink is not provided for the dead, Honer yet the stress laid on the permanence of the family, old Testa yet the stess laid lest the name of the dead be cut off from his place, is quite in keeping with the request of Elpenor to Odysseus to insure the continuance of his name in the memory of living men.

It is quite possible that, as the story of the interview of Odysseus with the dead reveals that the idea of the dead enjoying sacrifices of food and drink was familiar at that time, even though the periodical supply of such is not mentioned, so the existence of Laban's household gods and the gathering of the kindred of Jesse to their family ceremony ${ }^{1}$ may bear witness to the presence of a survival of ancestor-worship in some equivalent form, underlying the all-absorbing religion of the Israelites. At this day the spirits of Abraham, Isaac, and Jacob are considered by the Mohammedans of Hebron actually to inhabit the cave of Machpelah, and, in the case of Isaac at any rate, to be extremely angered by any negligence shown to their altars, either by omission of the customary ceremonies or by admission within the sacred precinct of any stranger of alien faith.

It must not therefore be inferred altogether that the regular ancestor-worship so-called was of later origin amongst the Greeks, but rather that the constitution of society did not afford it the same

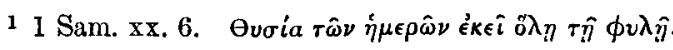


CHAP. I. prominence to the mind of Homer and perhaps his contemporaries, as it acquired later.

Ancestor- M. Fustel de Coulanges, in La Cité Antique, has worship in so well established the prevalence of ancestor-worship Rome. among the Greeks, drawing illustration both from Indian and Roman sources, that no further instances of its existence are needed here.

The ceremonies however and offerings at the tombs of their fathers did not supersede, amongst the Athenians at any rate, their worship of the Olympic gods. The Olympic gods themselves moreover were clearly connected with their family life. The protection of Zeus was specially claimed under

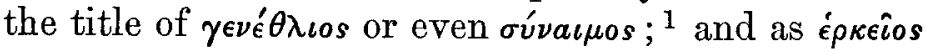
he received worship upon the altar that stood in the court-yard of nearly every house in Attica. ${ }^{2}$ The permanent place of these gods in the homes of the people is further denoted by the use of such epithets

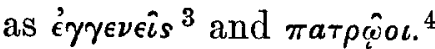

The need The tombs, on the other hand, were not approached the dead; with the purpose of invoking powerful aid, but rather with the intent of soothing a troubled spirit with care and attention, and of providing it with such nourishing refreshment as could not be procured in the regions of the starving dead.

'I come, bringing to my son's sire propitiating libations, such as are soothing to the dead, from hallowed cow white milk, sweet to drink; the flower distiller's dew-clear honey; the virgin spring's refreshing draught; and undefiled from its wild mother, the liquid gladness of the time-honoured vine ; also from the ever-

\begin{tabular}{l|llll} 
1 Soph. Antig. 659. & & & & \\
3 Soph. Antig. 199. & \\
4 Soph. Phil. 933. & Soph. \\
65. Coulanges, Cité Antique, p. & Elekt. 411. & &
\end{tabular}

leafy growth of the pale green olive fragrant fruit is here, and CBAP. I. twined flowers, children of the teeming earth.' 1

The same idea of nourishment of the dead, though the same shared with the other gods, determines the offerings in Egypt, in the Egyptian Book of the Dead. ${ }^{2}$

' I live upon loaves, white wheat, beer, red wheat . . . . Place me with vases of milk and wine, with cakes and loaves, and plenty of meat in the dwelling of Anubis.' 3

'Grant to me the funereal food, the drinks, the oxen, the geese, the fabrics, the incense, the oil, and all the good and pure things upon which the gods live.' 4

There is one passage that almost implies that the dead retained in idea a claim upon the produce of the land which nourished them whilst alive, or that they had a special allotment even in the other world :-

'I sit down among the very great gods of Nut. A field extends for me; the products of the ground are for me. I eat them; I am favoured with them; I live in plenty by them .... I am given corn and wheat for my mouth.'

Chapter cxliv. of the Book of the Dead is to be said,

'at the gate of every room while offering to each of them thigh and heads of red cows, the value of seven vases; while offering blood extracted from the heart, the value of a hundred vases sixteen loaves of white bread, eight round cakes, eight oval cakes eight broad thin cakes, eight measures of beer, and eight of wheat, a perfumed oil-basin full of milk from a white cow, green grass, green figs, mestem and beads of incense to be burnt.'

1 Aesch. Pers. 609-618. The speaker in this case is a Persian and a woman ; but many passages might be quoted from the Greek poets. Cf. Lucian, De Luctu, 9.

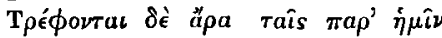

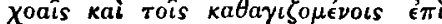

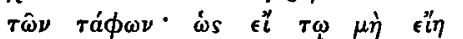

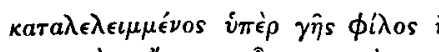

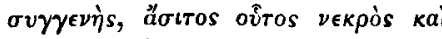

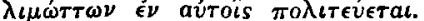

2 Edited by C. II. S. Davis

(Putnam, 1894).

3 Id. chap. liii.

${ }^{4} I d$. chap. lxxii.

5 Id. chap. Ixxvii. 
Chap. I. Chapter cxlviii. ordains that there

'shall be placed offerings before them of loaves, beer, meat, incense, funereal dishes, bringing into favour with $\mathrm{R} \hat{\mathrm{a}}$ and making that the deceased is fed in the netherworld.'

and in

In the next chapters frequent reference will be made to the offerings to ancestors, or manes, among the ancient Hindoos. With them the cake-offering to the dead became a most important symbol, uniting in a common duty all descendants from certain ancestors within fixed degrees, and marking them off in the matter of responsibility thereto from more distant relations, who owed similar duty elsewhere.

Being thus surrounded by nations that believed intensely in the need in the dead of nourishment at necessarily the hands of their relatives on earth, it would indeed postbe surprising if the Greeks were found not to share in
the belief. But the fact remains that in the earliest Greek literature it is least conspicuous, and the gulf seems widest between the living and the dead. Can this be laid to the charge of the artificial superstitions of a philosophical class of poets? Or is it due to the true evolution of such beliefs, that as long as our search touches upon the unsettled periods of semimigratory life, the tombs of individual members of a family being scattered here or there wherever they meet their deaths, the offering to the dead takes a special form, inasmuch as the solidarity of the tribe eclipses the importance of the family as a unit, and the religious ceremonies of the chieftain absorb the attention of the lesser members of the tribe?

M. de Coulanges points out that the meaning of the Latin word Lar is lord, prince or master, and that Hestia was sometimes designated by the Greeks Chap. J. with the similar title of mistress of the house, or princess. ${ }^{1}$

If, as long as the tribe was felt to be a real unit, the religious instincts of the tribesmen were concentrated upon the worship of their tribal deities-the great ancestors of the tribe, and more emphatically and directly the ancestors of their chieftain-it would be quite natural, in the weakening of the central worship, for the titles of honour and respect to be used equally towards those meaner ancestors who henceforth occupied the religious energies of the head of each family or household. In fulfilment of a similar sentiment, the later Greeks commonly used the word ñ one who departed this life passed to the ranks of those princes of the community from whom all were proud to trace descent.

M. de Coulanges considers that the sacred rites of The hearth the family at the hearth formed a more real tie than ${ }_{\text {tie of }}^{\text {and the }}$ the belief in a common blood; and that upon this common religious basis was built up the greater hearth of the Prytaneum as the centre of city life, to bind together the several families composing the community. But without pretending to come to a final decision on this the main tendency of social development, surely something may yet be said in favour of the contrary theory; that the reverence that centred in the hearth was in effect the expression of the sanctity of the tie of blood, as felt by all members of the house, and that this feeling drew its real importance for the com-

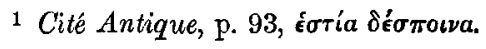


Crap. I. munity, not from the founding of the city by the amalgamation of several families, but as a survival from an earlier stage of life, when society circled round what was then in more than name the Prytaneum of the tribal chieftain.

Facts are wanting to justify a conclusion as to which of these theories bears the closest resemblance to the truth, but it is easy to imagine what might be the line of development if the latter hypothesis be maintained.

Possible During the wanderings and migrations of peoples course of in the search for greener pastures or broader lands, velopment. each community or tribe would be constantly under arms and subject to attack from the enemies they were passing through or subjugating. This constant sojourning in a strange land, surrounded by foes, would be a source of much solidarity to the tribe itself, drawing its members closely together for mutual defence and subsistence.

But when once the tribe had found a country to its taste, and had made a settlement with borders comparatively permanently established, emphasis would be transferred to the petty quarrels and internal dissensions arising between different sections within the community itself. The tie of common blood, uniting all members of the tribe, would be gradually disregarded and displaced by the less homely and more political relation of fellow-citizenship, which, though retaining many of the characteristics of the tribal bond, would necessarily be felt in a very different manner.

In this disintegration of the larger unit, the existence of kinship by blood would be acknowledged only where the relationship was obvious and well Crap. $I$. known. And it would no longer be sufficient merely to prove membership of a kindred; as those outside certain limits would claim exemption from the responsibilities entailed by closer relationship.

So, too, in the matter of religious observance: The the reverence of the individual for the Prytaneum change of and common hearth of the state would undergo a into change into a less personal sentiment; the rites connected therewith would be delegated to an official priest; and it is with the head of each family, surrounded by those who are really conscious of their connection by blood in common descent from much more immediate ancestors, that the true tribal feeling would longest survive, though, of course, on much narrower lines.

The privileges of citizenship were, it will be seen, as carefully guarded as those of the tribe, but in a more perfunctory and arbitrary manner; whilst the intimate connection of the members of the family with the hearth and the graves of their ancestors stands out in strong relief.

By the time of Hesiod, besides the violation of the universal sanctity of a guest or suppliant, the chief sins are against members of the same household, defrauding orphans, or insulting an aged parent. ${ }^{1}$ Behaviour to other than blood-relations is regulated by expediency, by what you may expect in return from your neighbours. ${ }^{2}$

Whether the family is to be regarded as the chief factor in the composition of the city, or how much of

\footnotetext{
${ }_{1}$ Wks. \& Days, 327-332. $\quad 2$ Id. 353-5.
} 
Chap. I. its composition the city owes to direct inheritance from the tribal system, must, as has been said, be left unsolved. Some small light may perhaps be shed upon the problem as this inquiry proceeds.

The study At any rate, if the true basis of the organisation of the of the family and the kindred, as found in historic introduc- times in Greece, could once be established, material tory to the assistance ought to have been gained for rightly the tribe. understanding the structure of that earlier society, whatever it was, from which the rules, that govern those within the bond of kinship, were survivals.

\section{CHAPTER II.}

THE MEANING OF THE BOND OF KINSHIP.

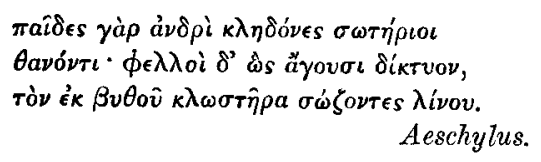

\section{§1. THE DUTY OF MAINTENANCE OF PARENTS DURING} LIFE, AND AFTER DEATH AT THEIR TOMB.

As the hearth was the centre of the sanctity and CHAP. II. reverence of the family, so the word oircos was the cus- The duties tomary term to signify the smaller group of the com- of the inposite $\gamma^{\prime} \in \bar{\nu}$, consisting of a man and his immediate his ofkos, descendants. In the first place, the individual was absolutely committed to sacrifice all his personal feelings for the sake of the continuity of his oikos, and this was his supreme duty. But whereas several oiko traced their descent from a common ancestor, a group of gradually diverging lines of descent were formed, sharing mutually the responsibility of the maintenance of continuity, and the privilege of inheritance and protection.

Before examining how far these parallel lines remained within the reach of claims of kinship, or how soon the reverence for the more immediate pre- 
Chap. II. decessors absorbed the memory of the more remote ancestor, it will be well to have a clear understanding of what the claims of kindred were, and how they affected the member of the oikos, in respect of his duties thereto.

began with Plato $^{1}$ declares that honour should be given to :parents ;

1. Olympian Gods.

2. Gods of the State.

3. Gods below.

4. Demons and Spirits.

5. Heroes.

6. Ancestral Gods

7. Living Parents, 'to whom we have to pay the greatest and oldest of all debts: in property, in person, in soul ; paying the debts due to them for the care and travail which they bestowed on us of old in the days of our infancy, and which we are now to pay back to them when they are old and in the extremity of their need.'

The candidates for the archonship were asked, among other things, whether they treated their parents properly. ${ }^{2}$ It was only in case of some indelible stain, such as wife-murder, that the debt of maintenance of the parent was cancelled. ${ }^{3}$ Yet and ex- even when the father had lost his right of maintended to theirtomb. tenance by crime or foul treatment, the son was still
the bound to bury him when he died and to perform all the customary rites at his tomb. ${ }^{4}$

\footnotetext{
1 Laws $\S 717$, Trans. Jowett, cf. $729 \mathrm{C}$ and $931 \mathrm{~A}$.

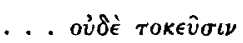

$931 \mathrm{~A}$.

2 Arist, Ath. Pol. lv. 3.
aeus, viii. 32. "The law commands us to maintain ( $\tau \rho \in$ ́́ $\phi \epsilon \nu$ ) our parents even if they have nothing to leave us.' $C f$. Ruth

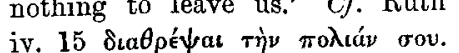

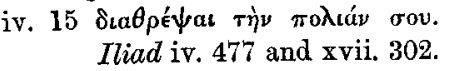

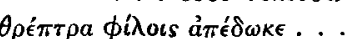

Hesiod, Works and Days, 118 oủố $\kappa \in \nu$ oíye

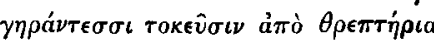
$\delta o \hat{i} \epsilon \nu$

$\chi \in i \rho o \delta i k a u$

3 Plato, Lavs, 877 c.

4 Aeschin. c. Timarch. \$13.
}

'Is it not,' says Isaeus, 'a most unholy thing, Crap. II. if a man, without having done any of the customary rites due to the dead, yet expects to take the inheritance of the dead man's property?' 1

The duty of maintenance of the parent thus Continuity extended even beyond the tomb, and this retrospec- of the tive attitude of the individual gives us the clue to his position of responsibility also with regard to posterity.

The strongest representation possible of this attitude is given in the Ordinances of Manu, where it is stated that a man 'goes to hell ' who has no son to offer at his death the funeral cake.

'No world of heaven exists for one not possessed inthe Ordiof a son.' The debt, owed by the living member of Mances of a family to his manes, was to provide a successor to perform the rites necessary to them after his own death.

' By means of the eldest son, as soon as he is born, a man becomes possessed of a son and is thus cleared of his debt to the manes.'

'A husband is born again on earth in his son.'

'If among many brothers born of one father, one should have a son, Manu said all those brothers would be possessed of sons by means of that son.

i.e. one representative was sufficient as regards the duties to the manes in the house of the grandfather.

'Thro' a son one conquers worlds, thro' a son's son one attains endlessness, and through the son's son of a son one attains the world of the Sun.'

'The sort of reward one gets on crossing the water by means of bad boats is the sort of reward one gets on crossing the darkness (to the next world) by means of bad sons.' ${ }^{2}$

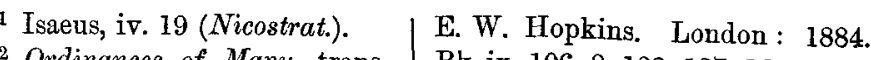

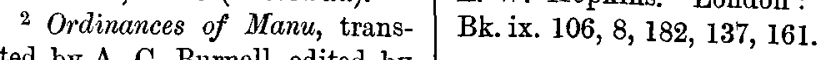
lated by A. C. Burnell, edited by 
Crap. II. Plato expresses the same feeling in the Laws: ${ }^{1}$

and ac-

cording to

Plato.
'After a sort the human race naturally partakes of immortality, of which all men have the greatest desire implanted in them; for the desire of every man that he may become famous, and not lie in the grave without a name, is only the love of continuance ... In this way they are immortal leaving [children's] children behind them, with whom they are one in the unity of generation. And for a man voluntarily to deprive himself of this gift of immortality, as he deliberately does who will not have a wife and children, is impiety.'

The functions and duties of the individual towards his family and relations thus find their explanation in his position as link, between the past and the future, in the transmission to eternity of his family blood.

His duties to his ancestors began with the death of his father. He had at Athens to carry out the corpse, provide for the cremation, gather the remains of the burnt bones, with the assistance of the rest of the kindred, ${ }^{2}$ and show respect to the dead by the usual form of shaving the head, wearing mourning clothes, and so on. Nine days after the funeral he must perform certain sacrifices and periodically after that visit the tombs and altars of his family in the family burying-place. ${ }^{3}$ If he had occasion to perform military service, he must serve in the tribe and the

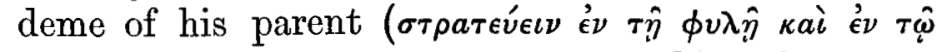
$\left.\delta \eta_{\mu}^{\prime} \omega\right) .{ }^{4}$ Before he can enter into his inheritance he must fulfil all the ordinances incumbent on one in his position, and in the Gortyn Laws it is

\begin{tabular}{l|l}
1 Laws, 721 в, Trans. Jowett, & ${ }^{3}$ Dem. c. Macart. 1077. \\
cf. $923 \mathrm{~A}$. & \\
2 Dem. c. Leoch. 1090, and $\pi$. & \\
xxiii. 163 , xvi. 455, xxiv. 793. &
\end{tabular}

stated that an adopted heir cannot partake of the CHAp. II. property of his adoptive father unless he undertakes the sacred duties of the house of the deceased. ${ }^{1}$ Thus the right of ownership of the family estate rested always with the possession of the blood of the former owners; and such a representative demonstrated his right by stepping into his predecessor's shoes and by taking upon himself all responsibility for the fulfilment of the rites, thereafter to be performed to him also when he shall have been gathered. to the majority of his family.

\section{§ 2. THE DUTY OF PROVIDING MALE SUCCESSION.}

But however piously and carefully he performed his many duties to his ancestors, his work was only transitory and incomplete, unless he provided a successor to continue them after him into further generations.

The procreation of children was held to be of such The imimportance at Sparta ${ }^{2}$ that if a wife had no children, $\begin{gathered}\text { portance of } \\ \text { male suc- }\end{gathered}$ with the full knowledge of her husband she admitted cession. some other citizen to her, and children born from such a union were reckoned as born to the continuation of her husband's family, without breach of the former relations of husband and wife. ${ }^{3}$ This is the exact custom stated in the Ordinances of Manu

\footnotetext{
1 Arist. Pol. 1, 2, 4, 'H $\mathrm{k \tau} \hat{\eta} \sigma \mathrm{s}_{\mathrm{s}}$ it would seem that such children, $\mu$ '́́

2 Plut. born into a family where there \begin{tabular}{l|l} 
Xen. Rep. Lac. i. 7 to 9. & were already children of both \\
father and mother, had no
\end{tabular}

${ }^{3}$ From Xen. Rep. Lac. i. 9, in the family property.
} 
Chap. II. (ix. 59), where it is laid down that a wife can be 'commissioned' by her husband to bear him a son, but she must only take a kinsman within certain degrees, whose connection with her ceases on the birth of one son. ${ }^{1}$ Otherwise it was a man's duty to divorce a barren wife and take another. But he must divorce the first, and could not have two hearths or two wives. ${ }^{2}$

A curious instance of how this sentiment worked in practice in directly the opposite direction to our modern ideas, is mentioned in Herodotus. Leaders of forlorn hopes nowadays would be inclined to pick out as comrades the unmarried men, as having least to sacrifice and fewest duties to forego. Whereas Leonidas, in choosing the 300 men to make their famous and fatal stand at Thermopylae, is stated to have selected all fathers with sons living. ${ }^{3}$

Hector is made to use this idea in somewhat similar manner. He encourages his soldiers with :-

'If a man fall fighting for his fatherland, it is no dishonourable thing: and his wife and his children left behind, and his oikos and $\kappa \lambda \hat{\eta} \rho$ s are unharmed, if the Achaians go but back to their own country.' 4

If the enemy are driven out, though he be killed himself, yet if he leave children behind, his household and their property will remain unharmed.

All about to die, says Isaeus, take thought not to leave their oikos desolate ( $\left.{ }^{*} \rho \eta \mu o s\right),{ }^{5}$ but that there shall be some one to carry the name of their house

\footnotetext{
1 This was the practice also in ${ }^{3}$ Herod. vii. 205. Quoted by Arabia (Rob. Smith, Kinship \&c., Hearn, Aryan Household, p. 71. p. 110).

2 Herod. v. 40.

4 Iliad xv. 497

5. Is. vii. 30 .
}

down to posterity, who shall perform all the customary CHap. II. rites at the tomb due to them also when they shall have joined the ranks of ancestors. ${ }^{1}$

Where children were reckoned of the tribe of their father and not of their mother, and where a woman was incapable of performing sacred rites, a male heir was necessary for the direct transmission of blood and property. Sons entered upon their inheritance immediately on the death of their father, nor had he the power to dispossess them in favour of others, whilst brothers, cousins, legatees, had always to prove their title and procure judgment from the court in their favour. ${ }^{2}$

Failing sons however, the next descent lay through succession a daughter. Nor were her qualifications in herself ${ }_{\text {danghter. }}^{\text {through }}$. complete or sufficient in theory to form the necessary link in the chain of succession. The next of kin male had to marry her with the property of which

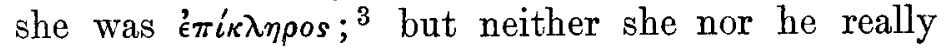
possessed the property, and the sons born from the marriage succeeded thereto directly on attaining a certain age. The next of kin had in the meantime of course to represent his wife's father in all the religious observances, and was said to have

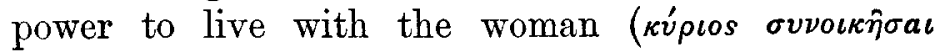

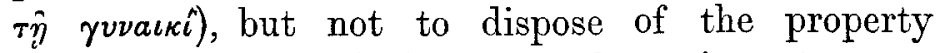

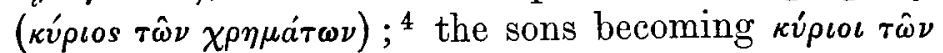
$\chi \rho \eta \mu a ́ \tau \omega \nu$ at sixteen years old, and owing thence only maintenance $\left(\tau \rho \epsilon^{\prime} \phi \epsilon \iota \nu\right)$ to their mother from

\footnotetext{
1 Is. ii. 36.

2 Is. iii. 59 and 60 , vi. 28 \begin{tabular}{ll|l}
2 & Is. iii. 59 and 60 , vi. 28. & dered by 'heiress.' \\
4 & For want of a better trans- & Is.
\end{tabular}

property' this word will be ren-

lation implying 'going with the Dem. in Neaeram 1386.
} 
Crap. II. the property. ${ }^{1}$ The heiress was compelled to marry at a certain age and was adjudicated by law to the proper kinsman. ${ }^{2}$

Again an exact parallel is to be found in the Ordinances of Manu:-

'One who is without a son should, by the following rule, make his daughter provide him a son :- "The offspring which may be hers shall be for me the giver of offerings to the manes."'

The whole property of a man is taken by this daughter's son, ${ }^{3}$ and, by her bearing a son, her father 'becomes possessed of a son, who should give the funeral cake and take the property.' 4

If she die without a son, her husband would take (presumably by a sort of adoption). ${ }^{5}$ But this would be perfectly natural, if, as in Greece, her husband was bound to be the next of kin and therefore heir failing issue from her.

She must At Athens it was part of the office of the archon mext of to see that no oînos failed for want of representakin, tives, to constrain a reluctant heiress to marry or to compel the next of kin to perform his duty. Plato ${ }^{6}$ asks pardon for his imaginary legislator, if he shall be found to give the daughter of a man in marriage having regard only to the two conditions-nearness of kin, and the preservation of the property ; disregarding, in his zeal for these, the further considerations, which the father himself might be expected

\begin{tabular}{|c|c|}
\hline 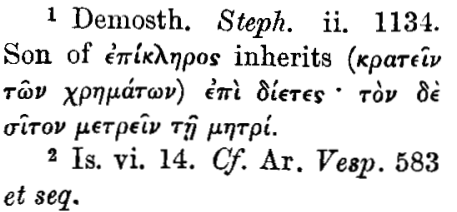 & $\begin{array}{l}3 \text { Manu ix. } 131 \text { and } 132 . \\
{ }^{4} \text { Ib. } 136 . \\
{ }^{5} \text { Ib. } 135 . \\
{ }^{6} \text { Laws, } 924 .\end{array}$ \\
\hline
\end{tabular}

to have had, with regard to the suitability of the CHap. II. match. ${ }^{1}$

A certain leniency was however allowed to the even heiress who was unwilling to marry an obnoxious already kinsman, and to the kinsman who had counterclaims upon him in his own house. Nevertheless the rules remained very strict. Isaeus states emphatically, ${ }^{2}$ ' Often have men been compelled by law to give up their properly wedded wives, owing to their becoming

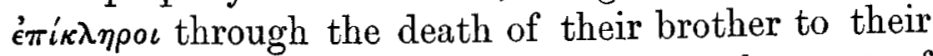
father's property and having to marry the next of

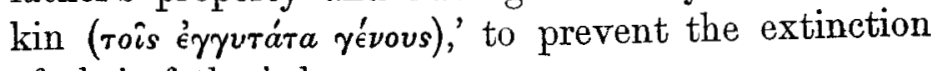
of their father's house.

Manu warns those about to marry to be careful that their children shall not be required to continue their wives' father's family, to the desolation of their own.

'She who has not a brother ... . let not a wise man marry her, through fear of the law about a daughter's son.' 3

\section{Again Isaeus :-}

'We, because of our nearness of kin, would have been compelled

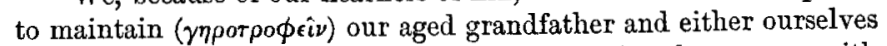
marry Cleonymos' (our uncle's) daughters or give them away with their portions to others and all this our kinship, the laws, and our shame would have compelled us to perform or incur the greatest penalties and the utmost disgrace.'4

In the laws of Gortyn very clear rules are laid

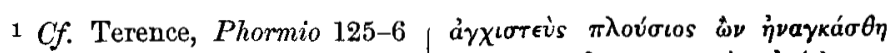

Lex est ut orbae, qui sunt genere proxumi,

Eis nubant, et illos ducere eadem haec lex jubet.

and Diod. Sic. xii. 18 é $\delta \grave{\epsilon}$

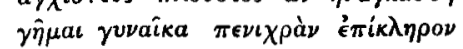

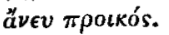

2 Isaeus, iii. 64.

3 Ordinances iii. 11.

4 Isaeus, i. 39 
Chap. II. down to be followed where there were difficulties in Similar the way of the heiress marrying the next of kin. rules in the

laws of

'The heiress shall marry the eldest brother of her father that is alive. If there are more heiresses and uncles, they shall ever marry the eldest. If there are ne uncles but sons of uncles, she shall marry the son of her father's eldest brother. If there are more than one heiress and sons of uncles, they shall ever marry the son of the eldest in order: but a man shall not marry more than one heiress' $\ldots .$. '

There is also a statement made by Demosthenes ${ }^{2}$ that sounds as if it might have come from the Ordinances of Manu. It is there stated that if there were more than one heiress, only one need be dealt with in respect to providing succession, though all shared in the property.

The law of Gortyn goes on :-

'If the man will not marry her, though of age and wishing to marry, the guardians of the heiress shall sue, and the judge shall condemn him to marry her in two months. If he will not marry her, according to the law, she shall have all the property and shall marry the next of kin (after him) if there is one ....

'If she is of age and does not wish to marry the next of kin or if he is a minor and she does not wish to wait, she . . . can marry whom she will of those who claim her of the tribe. But she shall apportion off his share of the property to the first of kin.

'If there are no kin to her, she shall have all the property and marry whom she will of the tribe.

'If no one of the tribe will marry her, her guardians shall ask throughout the tribe, "Will any marry her?" And if any one then marries her, he shall do it in thirty days after the "asking." But if there is still no one, she shall marry any one else she can.'

Such pains were taken to find a representative

1 vii. 15-ix. 24. We may $/$ therefore $\boldsymbol{\epsilon}^{\prime} \pi \dot{k} \boldsymbol{k} \lambda \eta \rho$ os of his brother compare this with Odyssey vii. 60 Rhexenor.

et seq. where Alkinoos marries his $\quad{ }^{2}$ c. Macart. 1068 (Law)

niece, Arete, the only child and for the deceased in his family, or at any rate Chap. II. in his tribe. ${ }^{1}$

The same questions seem to have arisen amongst and

the Israelites in the time of Moses. amongst

Numbers xxxvi. 8. 'And every daughter that possesseth an

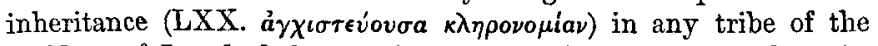
children of Israel, shall be wife unto one of the family of the tribe

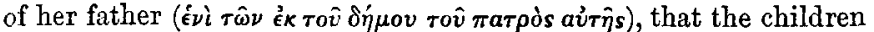

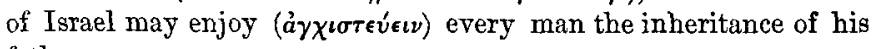
fathers.

'Even as the Lord commanded Moses, so did the daughters of Zelophehad.

'For Mahlah, Tirzah and Hoglah, and Milcah, and Noah, the daughters of Zelophehad, were married unto their father's brother's

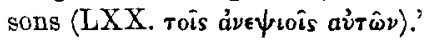

\section{§ 3. THE POSITION OF THE WIDOW WITHOUT CHILD AND THE DUTIES OF AN ONLY DAUGHTER.}

THE levirate, or marriage with deceased husband's The levirbrother, seems to have had no place in Greek family not found law. The wife was of no kin necessarily to the in Greece. husband; and so it would not tend to strengthen the transmission of blood if the next of kin married the widow on taking the inheritance of his relative deceased without issue. The wife in Greek law could not inherit from her husband, whose property went to his father's or mother's relations; and only when it became a question of finding an heir to her son, and failing all near paternal kinsmen, could the

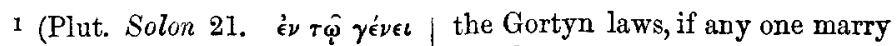

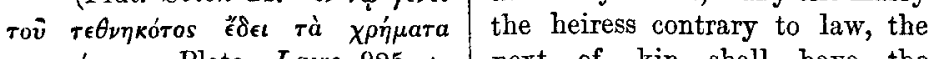
кarau'veiv. Plato, Laws 925 A. next of kin shall have the Heiress must marry a citizen. In property). 
Crap. II. inheritance pass through her, and then as the mother of her dead son, not as widow of her dead husband. Even then, being a woman, she had no right of enjoyment, only of transmission. She could only inherit on behalf of her issue by a second husband, and failing her issue the inheritance would pass to her brothers and so on. In Greece the claim upon the $\delta a \eta^{\prime}$ (Latin levir) for marriage seems to have begun with his brother's daughter, not his brother's widow.

The widow The childless widow on the death of her husband returned had to return to her own family or whoever of
to her

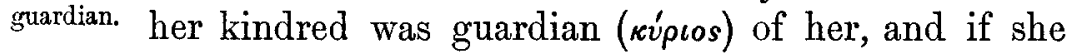
wished, be given again in marriage by him. ${ }^{1}$

The woman at Athens even after marriage always retained her кupıos or guardian, ${ }^{2}$ who was at once her protector and trustee. He was probably the head of the oikos to which she originally belonged-her next of kin-and had great power over her. ${ }^{3}$

A case there is ${ }^{4}$ where the heir to the property also takes the wife of the previous owner; but in this case the husband may have been kvipıs of his own

1 Dem. c. Macart. 1076. father; in her youth, of her husWidow only allowed to remain band; her husband being dead, in her deceased husband's house of her sons; a woman should on plea of pregnancy and under never enjoy her own will.'

the guardianship of the archon. Dem. c. Boeot. 1010. Wife leares her husband's house and is portioned out again by her brothers.

2 Cf. Ord. of Manu v. 147-8.

'No act is to be done according to (her) own will by a young girl, a young woman, or even by an old woman, though in (their own) houses.

'In her childhood (a girl) should be under the will of her
3 Dem. c. Spoud.1029. Father takes away daughter and gives her to another.

Cf. also Dem. c. Eubulid. 1311.

Isaeus, $\nabla .10 . \quad$ By coming into an inheritance from his first cousin, a man also becomes guar-

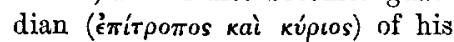
three female first cousins, though all married.

4 Dem. pro Phormio. 953. wife, and so could bequeath or give her away to whom- Crap. II. ever he liked. ${ }^{\mathrm{I}}$

In the Ordinances of Manu, the limitations of the levirate are very strictly defined. ${ }^{2}$ In the case of a man leaving a widow, she must not marry again, or she lost her place in heaven by his side.

But if she was childless, the next of kin of her husband must beget one son by her; he did not marry her, and his connection with her ceased on the birth of a son.

The laws of Manu otherwise are strict against the Marriage marriage of close relations; a restriction not found in $\begin{gathered}\text { of near } \\ \text { relations. }\end{gathered}$ Greece.

Isaeus ${ }^{3}$ mentions that it was thought quite natural for a man to marry his first cousin in order to concentrate the family blood, and prevent her dowry or whatever property might come to her from going outside his oikos, and we know that even marriage with a half-sister (not born of the same mother) was not forbidden.

There are more instances than one in Homer of a man marrying his aunt, or niece.

The nearest resemblance to the levirate in Greece is the occasional custom at Sparta, mentioned already, of a wife being 'commissioned' to bear children by another man into the family of her husband. But this exists in Manu, side by side with the abovementioned custom of levirate proper.

Among the Israelites, the levirate was in full force; the craving for continuance was the same as among the followers of Manu and the Greeks; and

\footnotetext{
1 As in Isaeus, ii. 7 and $8 . \quad 2$ ix. 70. \&c. $\quad 3$ vii. 11 and 12.
} 
Chap. II. the custom with regard to heiresses is so vividly told The levir. that it is worth quoting at some length.

ate among

ites.

Deut. xxv. 5. 'If brethren dwell together and one of them die and have no child, the wife of the dead shall not marry without unto a stranger : her husband's brother [i.e. next of kin] shall go in unto her and take her to him to wife and perform the duty of an husband's brother to her.

'And it shall be that the firstborn which she beareth shall succeed in the name of his brother that is dead, that his name be not put out of Israel.

'And if the man like not to take his brother's wife, then let his brother's wife go up to the gate unto the elders and say, "My husband's brother refuseth to raise up unto his brother a name in Israel, he will not perform the duty of my husband's brother."

"Then the elders of his city shall call him and speak unto him : and if he stand to it and say, "I like not to take her," then shall his brother's wife come unto him in the presence of the elders, and loose his shoe from off his foot, and spit in his face, and shall answer and say: "So shall it be done unto that man that will not build up his brother's house (LXX. oikos)."

"And his name shall be called in Israel, "The house (oikos) of him that hath his shoe loosed."

The case Such was the scorn felt for the man who refused to perform the duties of nearest kinsman. In the thirty-eighth chapter of Genesis is told the story of Tamar, the wife of Judah's eldest son who died childless. The second son's refusal to raise up seed to his brother because he knows that his own name will not be perpetuated thereby, but his brother's, meets with summary punishment. 'And the thing that he did was evil in the sight of the Lord, and He slew him also.' 1 Afterwards, when it was reported to her father-in-law that Tamar had a child by some one not of his family, he was exceedingly wroth, and said, ' Bring her forth and let her be burnt.' Accordingly, after he had received his own 'tokens' from her hand, his approval of her action, in her desire to perpetuate Cyap. IL. the name of her dead husband, is all the more striking, and shows how real such a claim as Tamar's was in the practice of those days, extreme though her action was felt to be. And Judah acknowledged his tokens and said, 'She hath been more righteous than I: because that I gave her not to Shelah my [youngest] son.'

The statement of the customary procedure in The case Deuteronomy is very picturesquely illustrated and of Ruth. fulfilled in detail in the story of Ruth, who though only a daughter-in-law takes the position of heiress through a sort of adoption by her mother-in-law Naomi, on her refusal to go back to her own people. 'Where thou goest, I will go: where thou lodgest, I will lodge: thy people shall be my people, and thy God, my God. Where thou diest will I die, and there will I be buried.' She accepts Naomi's hearth, her kin, her religion, and finally her tomb.

Elimelech and his two sons dying in Moab, Naomi and both her daughters-in-law are left widows in a strange land. If Naomi had other sons, upon them would have devolved the duty of taking Orpah and Ruth to wife. But Naomi declares herself ${ }^{1}$ too old to marry again and be the mother of sons, and implores her daughters-in-law to return to their own people in Moab, where she hopes they will start afresh with new husbands, a course which seems always to have been open to wives in tribal communities. Orpah does so, but Ruth elects to remain with Naomi, and returning with her to Bethlehem takes her chance

Ruth i. 8-12.

1 Gen. xxxviii. 10. 
Chap. II. among the kindred of Elimelech. Happening to arrive at Bethlehem at the beginning of the barley harvest, it so chances that Ruth goes forth to glean upon that part of the open field which belonged to Boaz-a rich man of the ovyrevia of Elimelech, who, having heard of her devotion to Naomi and the house of his late kinsmen, protects her from possible insult from strangers and treats her richly. On her return home Naomi informs her that Boaz is of their next of $\operatorname{kin}\left(\tau \hat{\omega} \nu \dot{a}^{\prime} \gamma \chi^{\iota \sigma \tau \epsilon \varepsilon o ́} \nu \tau \omega \nu\right)^{1}$ whose place it was to redeem property sold or lost by a kinsman. This duty is thus set forth in Leviticus:-

Lev. xxv. 25. 'And if thy brother be waxen poor and sell

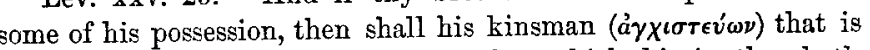
next to him come and shall redeem that which his brother hath sold.'

An instance of it in practice is given in Jeremiah.

Jerem. xxxii. 8. 'So Hanameel mine uncle's son came to me in the court of the guard according to the word of the Lord and in the court of the guard anto me, "Buy my field, I pray thee, that is in Anathoth which is in the land of Bethlehem : for the right of inheritance is thine, and the redemption is thine : buy it for thyself."

But on Ruth's applying to Boaz, he informs her that though he is ary

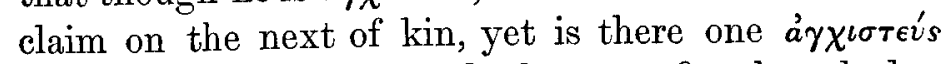
who is nearer than he, and who must first be asked.

'Now Boaz went np to the gate and sat down there, and behold the near kinsman of whom Boaz spake came by, unto whom he said, "Ho, such an one ! turn aside, sit down here," and he turned aside and sat down. And he took ten men of the elders of the city and said, "Sit ye down here," and they sat down. And

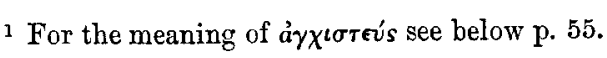

he said unto the near kinsman, "Naomi that is come again out of CHAP. II. the country of Moab selleth the parcel of land which was our

brother Elimelech's : and I thought to disclose it to thee, saying, 'Buy it before them that sit here and before the elders of my people.' If thou wilt redeem it, redeem it ; but if thou wilt not redeem it, tell me that I may know ; for there is none to redeem it beside thee, and I am after thee." And he said, "I will redeem it." Then sard Boaz, "What day thou buyest the field of the hand of Naomi thou must buy it also of Ruth the Moabitess, the wife of the dead, to rause up the name of the dead upon his inheritance." And the near kunsman said, "I cannot redeem it for myself lest $I$ mar my own inheritance; take thou my right of redemption on thee; for I cannot redeem it"....'

The rendering of the Vulgate of the kinsman's reply is more easily understood:-'I yield up my right of near kinship: for neither ought $I$ to blot out the continuance (posteritas) of my family: do thou use my privilege, which I declare that I freely renounce.'

'And he drew off his shoe. And Boaz said unto the elders and unto all the people, "Ye are witnesses this day that I have bought all that was Elimelech's . . . Chilion's and Mahlon's of the hand of Naomi. Moreover Ruth, the wife of Mahlon, have I purchased to be my wife to raise up the name of the dead upon his inheritance, that the name of the dead be not cut off from among his brethren and from the gate of his place : ye are witnesses this day." And all the people that were in the gate and the elders said, "We are witnesses . . . May thy house be like the house of Perez whom Tamar bare unto Judah "\&c.'

Now Boaz was sixth in descent from this Perez whose mother Tamar, as quoted above, had been in much the same position as Ruth.

It is interesting to read further that the son born of this marriage of Ruth and Boaz is taken by the women of Bethlehem to Naomi, saying, 'There is a son born to Naomi,' emphasising the duty of the heiress to bear a son, not into her husband's family, but to that of her father. 
Crap. II. The story of Ruth is not, therefore, an exact example of the custom of levirate. But it illustrates incidentally the unity of the family. The sons of Elimelech died before the family division had taken place, and the house of Elimelech their father was thus in jeopardy of extinction. If Naomi had come within the proper operation of the levirate, the next of kin ought to have married her, but by her adoption of Ruth as her daughter, she gave Ruth the position of heiress or é $\pi i \kappa \lambda \eta p o s$, whilst the heir born to Ruth was called son, not of Ruth's former or present husband, but of Elimelech and (by courtesy) of Naomi, Elimelech's widow, through whom the issue ought otherwise to have been found.

\section{§4. SUCCESSION THROUGH A MARRIED DAUGHTER GROWTH OF ADOPTION : INTRODUCTION OF NEW MEMBER TO KINSMEN.}

The son of But if the heiress was already married and had the heiress sons, she need not be divorced and marry the next of must leave
house, sidered sufficient if she set apart one of her sons to be heir to her father's house. But she must do this absolutely : her son must entirely leave her husband's house and be enfranchised into the house of her father. If she did not do this with all the necessary ceremonies, the house of her father would become extinct, which would be a lasting shame upon her.

Isaeus ${ }^{1}$ mentions a case where a wife inherits from her deceased brother a farm and persuades her husband to emancipate their second son in order that CHAP. II. he may carry on the family of her brother and take the property.

In another passage ${ }^{1}$ the conduct of married sisters and enter in not appointing one of their own sons to take his that of place as son in the house of their deceased brother, $\begin{gathered}\text { ceased } \\ \text { relative. }\end{gathered}$ and in absorbing the property into that of their husbands, whereby the oikos of their brother became "ै $\rho \eta \mu o s$, is described as shameful (ai $\sigma \chi \rho \hat{\omega} s)$.

In Demosthenes ${ }^{2}$ a man behaving in similar wise is stigmatised as $\dot{v} \beta \rho \iota \tau \tau \eta$ s.

Herein lay the reason that adoption became so Hence the favourite a means in classical times of securing an custom of heir. It became almost a habit among the Athenians who had no sons, to adopt an heir-often even the next of kin who would naturally have succeeded to the inheritance. ${ }^{3}$

The transfer of the adopted son from the oikos of his father to the oikos he was chosen to represent was so real that he lost all claim to inheritance in his original family, and henceforth based his relationship and rights of kinship from his new position as son of his adoptive father. This absolutely insured the childless man that his successor would not merge the inheritance in that of another oikos, and made it extremely unlikely that he would neglect his religious duties as they would be henceforth his own ancestral rites.

Sometimes, it seems, ${ }^{4}$ sons of an unfortunate

\begin{tabular}{|c|c|}
\hline 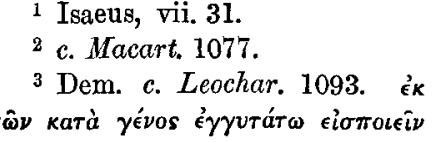 & 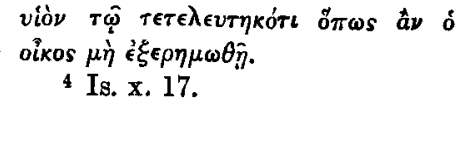 \\
\hline
\end{tabular}


Chap. II. father were adopted into another oikos so as not to share in the disgrace brought upon their family. In such a case presumably their father's house would be allowed to become extinct. The intro. The inheritance of property being only an accessory
duction of to the heirship, ${ }^{1}$ the ceremony of adoption consisted

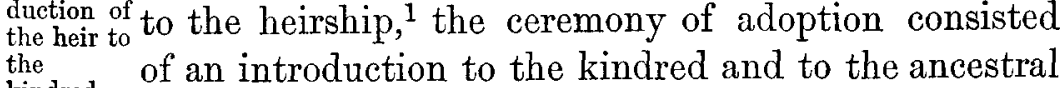
kindred. altars, and an assumption of the responsibilities connected therewith. The same The process was the same as for the proclamation
for true as of the true blood of a son, and was exactly in accord-
for adopt. of the for adopt- of the true blood of a son,
ed son. ance with tribal instincts.

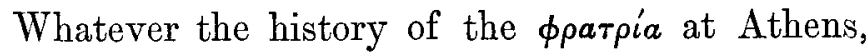
in it seems to have been accumulated a great number of the survivals of tribal sentiment.

The adoption at Athens took place at the gathering mony at of the phratores in order that all the kin might be

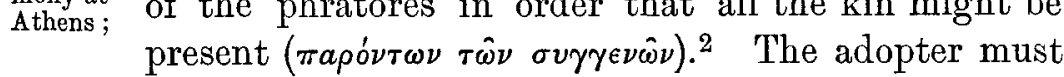
lead his son to the sacrifices on the altars ${ }^{3}$ and must show him to the kinsmen ( $\sigma \nu \gamma \gamma \epsilon \nu \epsilon \hat{\iota}$ or $\gamma \epsilon \nu \nu \hat{\eta} \tau a \iota)$ and phratores: he must give assurance on the sacrifices that the young man was born in lawful wedlock from free eitizens. This done, and no one questioning his rights, the assembly proceeded to vote ${ }^{4}$ and if the vote was in his favour, then and not till then he was enrolled

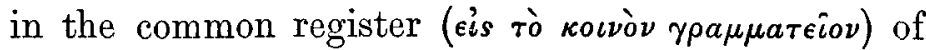
the phratria in the name of son of his adopted father. As a father could not without reason disinherit his true-born sons, so the phratores could not without reason refuse to accept them to the kinship. ${ }^{5}$

\begin{tabular}{|c|c|}
\hline 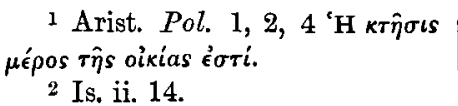 & $\begin{array}{l}3 \text { Is. vii. } 1,16,13 \text { and } 27 . \\
{ }^{4} \text { Dem. c. Eubulid. } 1315 . \\
5 \text { Is. vi. } 25 .\end{array}$ \\
\hline
\end{tabular}

If any of the phratores objected to the admission Снар. Ir. of the new kinsman, he must stop the sacrifices and remove the victim from the altar. ${ }^{1}$ He would have to state the grounds of his objection, and if he could not produce good reasons, he incurred a fine. If there was no objection, the unsacrificial parts of the victim were divided up and each member took home with him his share, ${ }^{2}$ or joined in a feast provided by the father of the admitted son. ${ }^{3}$

The ceremonial given in the Gortyn laws is and at similar :-

x. 33. 'The adoption shall take place in the agora when all the citizens have assembled, from the stone from which speeches are made. And the adopter shall give to his own brotherhood

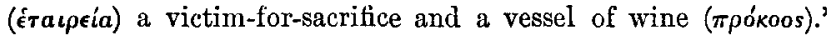

The adopted son gets all the property and shall fulfil the divine and human duties of his adoptive father ${ }^{4}$ and shall inherit as in the law for true-born sons. But if he does not fulfil them according to law, the next of kin shall take the property. He can only renounce his adoption by paying a fine.

The adopted son thus introduced was considered to have become of the blood of his adoptive father, and was unable to leave his new family and return to his original home unless he left in the adoptive house a son to carry on the name to posterity. As long as he remained in the other oikos, i.e. had not provided for his succession and by certain legal ceremonies been readmitted to his former family, he

\begin{tabular}{|c|c|}
\hline $\begin{array}{l}1 \text { Andoc. de Myst. } 126 . \\
2 \text { Dem. c. Macart. } 1054 \text { and } \\
\text { 1078. } \\
3 \text { Dem. c. Leoch. 1091. Isaeus } \\
\text { iii. } 80 \text { and viii. } 18 .\end{array}$ & 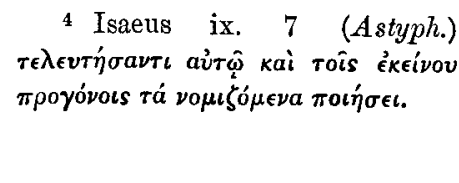 \\
\hline
\end{tabular}


Crap. II. was considered of no relationship to them and had no right of inheritance in their goods. ${ }^{1}$

An adopted son could not adopt or devise by will, and if he did not provide for the succession by leaving a son to follow him, the property went back into the family and to the next of kin of his adopted father. ${ }^{2}$

If he did return to his former oîsos, leaving a son in his place and that son died, he could not return and take the property thus left without heir direct. ${ }^{3}$

and also Adoption amongst the Hindoos took place in like manner before the convened kindred. The adopting father offered a burnt-offering, and with recitation of holy words in the middle of his dwelling completed the adoption with these words :-

' I take thee for the fulfilment of my religious duties; I take thee to continue the line of my ancestors." 4

The adopted son should be as near a relation as possible, and when once the ceremony had taken place, was considered to have as completely lost his position in his former family as if he had never been born therein. ${ }^{5}$

The intro- The introduction into the deme which took place at duction to the age of eighteen at Athens, including the enrolment
the deme. in the $\lambda \eta \xi\llcorner a \rho \chi\llcorner\kappa o \nu ~ y p a \mu \mu a \tau \epsilon i o n$, seems to have been a registration of rights of property and an assumption

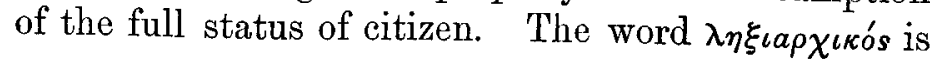

\begin{tabular}{l|l}
\hline Isaeus vi. $44 ;$ ix. 2 and $33 ;$ & 3 Ib. 1090. \\
$\begin{array}{l}2 \text { and } 4 . \\
\text { Dem. c. Leoch. passim. Cf. Cf. }\end{array}$ & $\begin{array}{l}\text { p. } 105 \text { and } 162 . \\
\text { Manu ix. 142. }\end{array}$ \\
$\begin{array}{c}\text { O Dem. c. Leoch. 1094, p. 141-2 and 189. } \\
\text { and (lex Solonis) 1100. }\end{array}$ & $\begin{array}{l}\text { Manu ix. 142. He offers no cake } \\
\text { to his original ancestors. }\end{array}$
\end{tabular}

defined by Harpocration as meaning 'capable of Cнар. II.

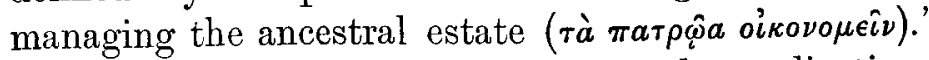
The word $\lambda \hat{\eta} \xi \iota s$ is used by Isaeus for the application, by others than direct descendants, to the Archon for the necessary powers to take their property.

It appears to have been at this period that the young man left the ranks of boyhood and dedicated himself to the responsibilities of his life.

Plutarch ${ }^{1}$ states that it was the custom at coming The cusof age to tonsure the head and offer the hair to some tomsure. god, and describes the young Theseus as adopting what we know as the Celtic tonsure, thenceforth called after his name.

'The custom still being in existence at that time for those quitting childhood to go to Delphi and dedicate ${ }^{2}$ their hair to the god, Theseus also went to Delphi (and the place is still called after him the Theseia, so they say) and shaved the hair of his head

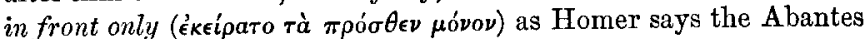
do $:^{3}$ and this kind of tonsure (кovpá) is called "Thesels" because of him. Now the Abantes first shaved themselves in this manner, not in imitation of the Arabs ${ }^{4}$ as some have it, nor even in emulation of the Mysians, but being a warlike people and fighting hand to hand, ... as Archilochos testifies. For this reason Alexander is said to have ordered his Macedonians to shave their beards . . '

This cutting the hair as token of dedication to any particular object or deity was of common occurrence. Achilles' hair was dedicated as an offering to the river Spercheios in case of his safe return. ${ }^{5}$ Knowing that this is impossible, in his grief at the death of Patroklos, with apologies to the god he cuts his

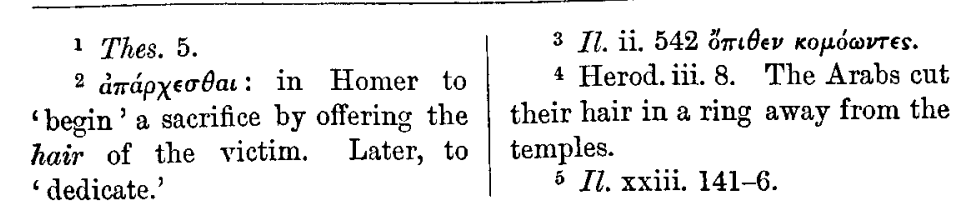


CHAP. II. flowing locks and lays them in the hand of his dead friend.

Pausanias declares that it was the custom with all the Greeks to dedicate their hair to rivers. ${ }^{\mathrm{I}}$

Theophrastus ${ }^{2}$ mentions as a characteristic of the man of Petty Ambition that he will 'take his son away to Delphi to have his hair cut (ámoкєipaı),' showing that this venerable custom had by that time become pedantic and an object of ridicule.

According to Athenaeus, ${ }^{3}$ when the young men cut their hair they brought a large cup of wine to Herakles and, pouring a libation, offered it to the assembled people to drink.

The age at which the hair was cut seems to have varied. The Ordinances of Manu ${ }^{4}$ give the following instructions :-

'The Keçanta (tonsure-rite) is ordered in the sixteenth year ${ }^{5}$ of a Brahman, in the twenty-second of a $K_{\text {șatriya, and in two years }}$ more after that for a Vaicya.'

But whenever the actual tonsure was performed, it seems to have been a very widely spread custom, symbolical in some way of devotion to a deity or kindred, or to some particular course of life.

Its importance in this place, however, lies in its being one of the special acts relating to the admission to tribal status, and to the devotion, so to speak, of the services of the individual to the corporate needs of his tribe or kindred.

The public introduction to the kindred, combined

\begin{tabular}{ll|r}
1 & Paus. i. $37,3$. & $5 f$ ii. 38. This was the last \\
2 & Char. 21. & year that a Brahman could receive \\
3 & Deipnosoph. xi. 88. & investiture. \\
4 & Manu ii. 65.
\end{tabular}

with publicity of marriage and of the birth of Chap. II. children would, it is obvious, be a very important protection for the preservation of the jealously guarded purity of the tribal blood. Isaeus ${ }^{1}$ says that all relations ( $\left.\pi \rho \circ \sigma \eta^{\prime} \kappa o \nu \tau \epsilon s\right)$, all the phratores, and most (oi $\pi \circ \lambda \lambda o^{i}$ ) of the demesmen would know whom a man married, and what children he had. This, in addition to the oath ( $\pi i \sigma \tau \iota s$ ) of the father or of the mother ${ }^{2}$ of the legitimacy of the son introduced to his kin, would seem a very sufficient safeguard. ${ }^{3}$

If a child was not introduced to the phratores, it was considered illegitimate, ${ }^{4}$ and could have no share in the rites of kindred and property. ${ }^{5}$

\section{§5. THE LIABILITY FOR BLOODSHED.}

A notable feature of the tribal system all over the Liability world was the blood-feud, wiped out only by the death shed rested of the manslayer or by the payment of a sufficient of a group recompense. The incidence of the responsibility for men. murder and for payment of the recompense upon a group instead of only on the guilty individual was of remarkable tenacity, and survived to comparatively late days.

In Arabia the whole tribe of the murderer subscribed to the blood-money, which went to all the males in the tribe of the murdered man. ${ }^{6}$

\footnotetext{
1 Isaeus, vi. 10.

2 Anc. Grk. Inscr. Brit. Mus. ccexv. cccxvii. and cecxviii. Oath of mother required before legitimacy registered, in the island of Kalymna.

${ }^{3} C f$. Aristot. Ath. Pol. xlii.

4 Isaeus, iii. 75.

5 Ib. vi. 47. Cf. Deuteronomy xxiii. i.

6 Robertson Smith, Kinship, \&c., in Arabia, p. 262.
} 
Chap. II. But in Greece the responsibility fell upon the next of kin, with the help and under the supervision of the rest of the immediate kindred. He had to see that a spear was carried in front of the funeral of the slain man and planted in his grave, which must be watched for three days. ${ }^{1}$ He must make proclamation of the foul deed at the tomb, and must undergo purificatory rites, himself and his whole house (oikia). If the dead body be found in the country and no cause of death known, the demarch must compel the relatives to bury the corpse and to purify the deme on the same day. ${ }^{2}$

The subject is a familiar one in Homer. The wanderer ( $\left.\mu \epsilon \tau a \nu a^{\sigma} \sigma \tau s\right)$ is said to have no value (he is

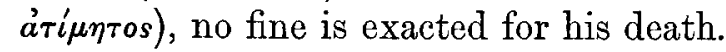

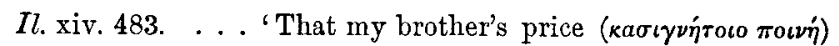
be not unpaid: even for this it is that a man may well pray to

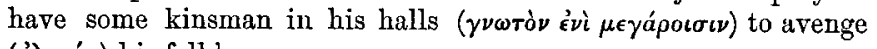

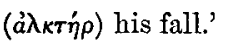

1l. ix. 634. 'Yet doth a man accept recompense of his brother's murderer : or for his dead son : and so the manslayer for a great price abideth in his own land ('ं $\nu \delta \dot{\eta} \mu \omega)$ and the other's heart is appeased and his proud soul, when he hath taken the recompense.' 3

No ransom There are many men told of in the Iliad and murders Odyssey who were in the position of refugees at the within the court of some chief. As many of them were wealthychiefs' sons or even chiefs_-and well able to pay large recompenses, it seems probable that (as is definitely stated in some instances), if the murder was committed on a member of the same family or tribe as the murderer,

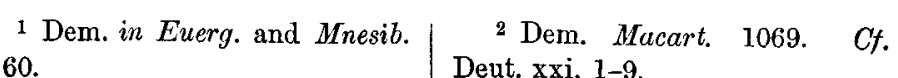
1160. ${ }^{3}$ Cf. Od. iii. 195.
}

the only way to wipe out the stain was by death or Chap. II. perpetual exile, as in the case of the typical fratricide Cain. The blood-price was then only between tribe and tribe or city and city. Within the kindred there would be no ransom allowed. ${ }^{1}$

Medon had slain the brother of his step-mother and was a fugitive from his country. ${ }^{2}$

Epeigeus ruled (" but having slain a good man of his kin (àveభróv), to Peleus fled, a suppliant. ${ }^{3}$

Tlepolemos slew his own father's maternal uncle, gathered much folk together and fled across the sea, because the other sons and grandsons of his father threatened him. ${ }^{4}$

Il. xxiv. 479. 'And as when a grievous curse cometh upon a man

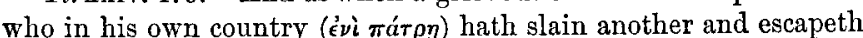
to a land of other folk ( $\delta \hat{\eta} \mu \nu \nu \hat{a} \lambda \lambda \omega \nu$ ) to the house of some rich man, and wonder possesseth them that look on him. . . .'5

Od. xv. 272. 'Having slain a man of my tribe $(\epsilon) \mu \phi \nu \lambda o \nu)$ :

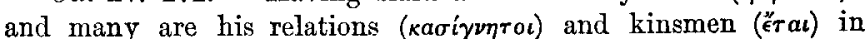
Argos: at their hands do I shun death and black fate and am in exile.'

Od. xxiii. 118. 'For whosn hath slain but one man in his country ('ยे $\delta \dot{\eta} \mu \omega)$ for whom there be not many avengers

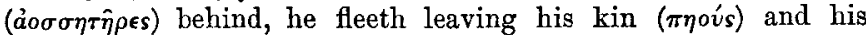
fatherland, how then we who have slain the pillar of the state!'

If ransom there was none for the murderer within or bethe tribe, there was equally none for murders between ${ }_{\text {citizen and }}^{\text {tween }}$ citizen and citizen,-in this point also the inheritors of citizen. the sentiments of tribesmen. In the law of Solon ${ }^{6}$ it

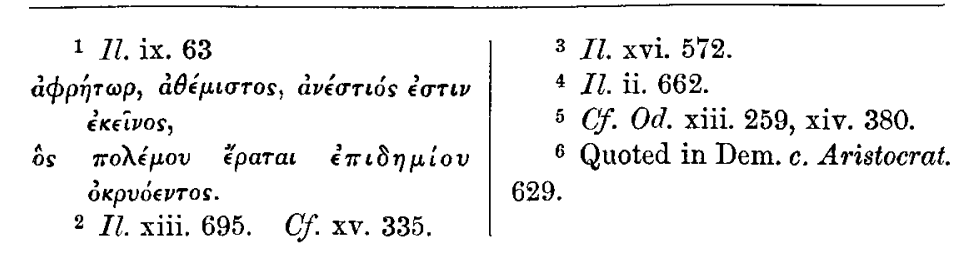


Cнир. II. was forbidden to take payment in compensation from the murderer :-

'The murderer can be slain in our land, not tortured, not held

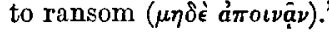

Plato $^{1}$ describes the soul of the deceased as troubled with a great anger against the murderer, so that even the innocent and unintentional homicide must needs flee at any rate for a year. The presence too of a man thus defiled with bloodshed at the sacred altars was held to be a gross impiety and source of divine anger. Plato ${ }^{2}$ says :-

'The murderer shall be slain, but not buried in the country ( $\chi \omega \rho a)$ of the deceased, which would be a disgrace and impiety.' 3

In the case of a suicide, the hand that committed the crime was to be cut off and buried separately.

In Isaeus ${ }^{4}$ it is related how Euthukrates in a quarrel over a boundary-stone was so flogged by his brother Thoudippos that, dying some days after, he charged his friends (oikeinc) not to allow any of Thoudippos' people ( $\tau \dot{\omega} \nu \Theta o v \delta i \pi \pi o v)$ to approach his tomb. But if the murdered man before his death forgave his murderer, the relatives could not proceed against him.

If the murderer escaped fleeing he must go for ever : if he returned he could be killed at sight by any one and with impunity. ${ }^{5}$ The pollution rested on the whole kindred of the murdered man.

- Whosoever being related to the deceased on the male or female side of those within the cousinship shall not prosecute the murderer when he ought or proclaim him outlaw, he shall take upon himself

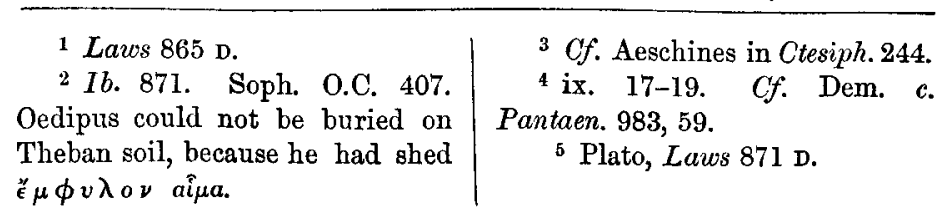

the pollution and the hatred of the gods . . . and he shall be in the CHap. II. power of any who is willing to avenge the dead.' 1

The pollution cannot be washed out until the homicidal soul has given life for life and has laid to sleep the wrath of the whole family $\left(\xi \nu \gamma \gamma^{\prime} \nu \epsilon \iota a\right) .{ }^{2}$

If it is a beast that has killed the man, it shall be slain to propitiate the kin and atone for the blood shed.

If it is a lifeless thing that has caused death, it shall solemnly be cast out before witnesses to acquit the whole family from guilt. ${ }^{3}$

Amongst the Israelites, treating of homicides amongst themselves, compensation was forbidden in like manner.

Numbers xxxv. 31. 'Moreover ye shall take no satisfaction for the life of a murderer which is guilty of death : but he shall surely be put to death.

'. . . The land cannot be cleansed of blood that is shed therein but by the blood of him that shed it.'

Let us complete this subject with the following story told by Herodotus : ${ }^{4}$-Adrastus, having slain his brother, flees to the court of Croesus. There he becomes as a son to Croesus and a brother to Atys, Croesus' son. This Atys Adrastus has the terrible misfortune to slay, thereby incurring a three-fold pollution. He has brought down upon himself the triple wrath of Zeus Katharsios, Ephestios, and Hetaireios: he has violated his own innocence, his protector's hearth, and the comradeship of his friend.

In despair he commits suicide.

\footnotetext{
1 Plato, Laws 871 в. Cf. 868.

2 Ib. 872 e. Cf. Tacitus, Germania,21 Suscipere taminimicitias seu patris seu propinqui quam amicitias necesse est. Nec implacabiles durant: luitur enim etiam homicidium certo armentorum ac pe-

\author{
corum numero, recipitque satisfac \\ tionem universa domus, utiliter in \\ publicum, quia periculosiores sunt \\ nimicitiae juxta libertatem. \\ ${ }^{3} \mathrm{Ib} .873 \mathrm{E}$. \\ 4 Herod. i. 44
}




\section{CHAPTER III}

\section{THE EXTENT OF THE BOND OF KINSHIP.}

Arctior vero colligatio est societatis propinquorum : ab illa enim immensa societate humani generis in exiguum angustumque concluditur.

Cicero.

\section{$\S 1$. DEGREES OF BLOOD-RELATIONSHIP ; THE}

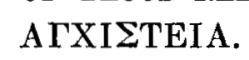

Chap. III. SUCH being the character of the burden of mutual All kins- responsibility borne by members of kindred blood, it men were remains, if possible, to obtain some idea of how this equally re-responsibility became narrowed and limited to the sponsible. nearest relations, and what was the meaning underlying the distinction drawn between certain degrees of relationship.

When examining the more detailed structure of the organisation of the kindred, considerable light seems to be thrown upon survivals in Athens by comparison with the customs of other communities, which were undergoing earlier stages of the same process of crystallisation from the condition of seminomadic tribes into that of settled provinces or kingdoms.
In the Gortyn Laws we read:-

CHAP. III.

iv. 24. "The father shall have power over the children and the The unity property to divide it amongst them ... As long as they (the of the parents) are alive, there is no necessity for division. . . If a man or oikos. woman die their children, or grandchildren, or great-grandchildren, shall have the property ... ?

The headship of the oikos and the ownership of the property vested in the parent as long as he lived and wished to maintain his power. Even after his death, unless they wished it, the sons need not divide up amongst themselves, but could live on with joint ownership in the one oikos of their deceased father. The eldest son would probably take the house itself, i.e. the hearth, with the duties to the family altars which devolved upon him as head of the family. ${ }^{1}$

An example of this joint ownership occurs in the speech of Demosthenes against Leochares. ${ }^{2}$ The two sons of Euthumachos after his death gave their sister in marriage (no doubt with her proper portion), and lived separately but without dividing their inheritance ( brother, they still left the property undivided, each living on his share of the income, one in Athens, the other in Salamis.

The possibility of thus living in one oînos and on an undivided patrimony is implied in another passage in Demosthenes, where, however, the exact opposite is described as actually having taken place. ${ }^{3}$

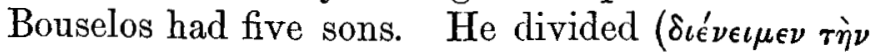
ov $\sigma^{\prime}(a \nu)$ his substance amongst them all as was fair and right, and they married wives and begat children and

1 v. infra p. 90 et seq. ${ }^{3}$ Dem. c. Macart. 1055-6.

2 c. Leoch. 1083. 
Cuar. III. children's children. Thus five oiko sprang up out of the one of Bouselos, and each brother dwelt apart, having his own oikos and bringing up his own off-

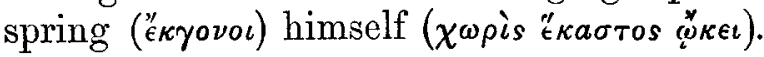

Whilst the parents were alive the family naturally held very closely together, and often probably lived in one patriarchal household like Priam's at Troy.

Isaeus declares:-The law commands that we

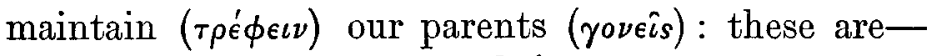
parents, grandparents and their parents, if they are still alive :

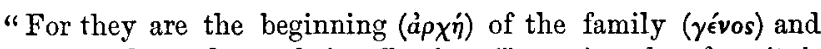
their estate descends to their offspring ("̈́rovor): wherefore it is necessary to maintain them even if they leave nothing." 1

The duty of maintenance ( $\left.\tau \rho^{\prime} \boldsymbol{\phi} \phi \epsilon \nu\right)$ owed to the ancestor would follow the same relationship as the right of inheritance from him, and this common debt towards their living forebears could not help further consolidating the group of descendants already bound together by common rites at the tombs of the dead.

But granted this community of rights and debts, is it possible to formulate for the Greeks anything of the same limitations in the incidence of responsibility amongst blood-relations that is to be found elsewhere?

Grades of In western Europe, owing perhaps to the in${ }_{\text {Western }}^{\text {kinship }}$ fluence of Christianity, the rites of ancestor-worship Europe. have no prominence. Ecclesiastical influence however was unable to prevent an exceedingly complex subdivision of the kindred existing in Wales and elsewhere. Whether this subdivision finds its raison d'être in the worship of ancestors or not, the groups thus formed serve as units for sustaining the respon- Chap. III. sibilities incident to tribal life, and being, as will be seen, governed by similar considerations to those existing among the Greeks, they afford very suitable material for comparison, and throw considerable light upon one another.

As the various departments affected by blood- The posirelationship or purity of descent come under notice, great- $_{\text {tion }}$ it will be seen that the position of great-grandson grandson, as at once limiting the immediate family of his parents and heading a new family of descendants is marked with peculiar emphasis.

In the ancient laws of Wales it rests with great- in Wales, grandsons to make the final division of their inheritance and start new households.

Second cousins may demand redivision of the heritage descending (and perhaps already divided up in each generation between) from their greatgrandfather. After second cousins no redivision or co-equation can be claimed. ${ }^{1}$

In the meanwhile the oldest living parents maintained their influence in family matters. In the story of Kilhwch and Olwen, in the Mabinogion, the father of Olwen, before betrothing her to Kilhwch, declares that ' her four great-grandmothers and her four greatgrandsires are yet alive; it is needful that I take counsel of them.' 2

Even when feudalism refused to acknowledge and in other than an individual responsibility for a fief, it ${ }_{\text {Nor- }}^{\text {feul }}$ was unable to overcome the tribal theory of the mandy.

\begin{tabular}{l|l}
1 Venedotian Code, ii. xii. & $\begin{array}{c}2 \text { Lady Charlotte Guest's Mab- } \\
\text { inogion, p. } 234 .\end{array}$
\end{tabular} 
Crap. III. indivisibility of the family, which maintained its unity in some places even under a feudal exterior. But as generations proceeded, and the relationships within the family diverged beyond the degree of second cousin, a natural breaking up seems to have taken place, though in the direction of subinfeudation under the feudal enforcement of the rule of primogeniture, instead of the practice, more in accordance with tribal instincts, of equal division and enfranchisement. It may however be surmised that the subdivision and subinfeudation of a holding in the occupation of such a group of kinsmen would be carried out by the formation of further similar groups.

In the Coustumes du Pais de Normandie mention is made of such a method of land-holding, called parage. It consists of an undivided tenure of brothers and relations within the degree of second cousins.

The eldest does homage to the capital lord for all the paragers. The younger and their descendants hold of the eldest without homage, until the relationship comes to the sixth degree inclusive (i.e. second cousins). When the lineage is beyond the sixth degree, the heirs of the cadets have to do homage to the heirs of the eldest or to whomsoever has acquired the fief. Then parage ceases. ${ }^{1}$

The tenure then becomes one of subinfeudation. As long as the parage continued, the share of a deceased parager would be dealt with by redivision of rights, and no question would arise of finding heirs. But when it became a question of finding an heir to the group, failing heirs in the CHAP. III. seventh degree inclusive, that is, son of second cousins-looked upon as son to the group-failing such an heir, the estate escheated to the lord.

There is an interesting passage in the Ancient Laws Co-heritof Wales ordaining that the next-of-kin shall not in- $\stackrel{\text { age in }}{\text { Wales. }}$ herit as heir to his deceased kinsman, but as heir to the ancestor, who, apart from himself, would be without direct heir, i.e. presumably their common ancestor.

'No person is to obtain the land of a co-heir, as of a brother, or of a cousin, or of a second cousin, by claiming it as heir to that one co-heir who shall have died without leaving an heir of his body : but by claiming it as heir to one of his own parents, who had been owner of that land until his death without heir, whether a father, or grandfather, or great-grandfather: that land he is to have, if he be the nearest of kin to the deceased.' 1

This of course refers to inheritance within the group of co-heirs, the members of which held their position by virtue of their common relationship within certain degrees to the founder. And we may infer that emphasis was thus laid on the proof of relationship by direct descent, in order to prevent shares in the inheritance passing from hand to hand unnoticed, beyond the strict limit where subdivision could be claimed per capita by the individual representatives of the diverging stirpes.

The kindred in the Ordinances of Manu is Degrees of divided into two groups:- $\quad \begin{aligned} & \text { relation } \\ & \text { ship in }\end{aligned}$

1. Sapindas, who owe the funeral cake at the India. tomb.
1 Dimetian Code, ii. xxiii. 
Crap. III. 2. Samānodakas, who pour the water libation at the tomb.

'To three ancestors the water libation must be made ; for three ancestors the funeral cake is prepared; the fourth (descendant or generation) is the giver (of the water and the cake); the fifth has properly nothing to do (with either gift.).' 1

This may be put in tabular form :-

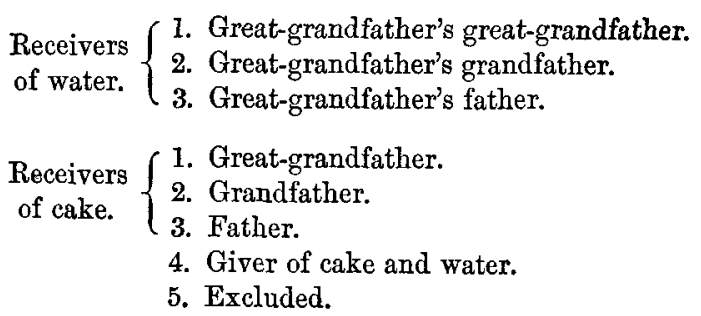

\section{Or inversely :-}

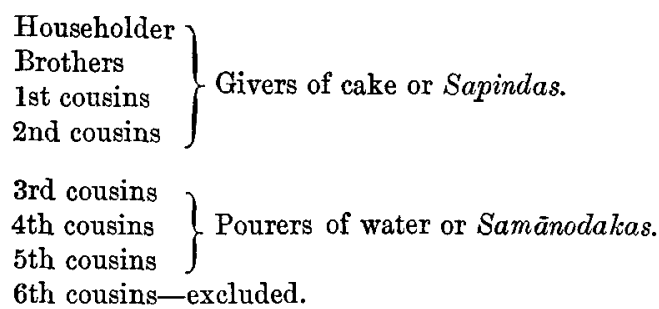

Within the Sapinda-ship of his mother, a 'twiceborn ' man may not marry. ${ }^{2}$ Outside the Sapindaship, a wife or widow, 'commissioned' to bear children to the name of her husband, must not go.

'Now Sapinda-ship ceases with the seventh person, but the relationship of a Samānodaka (ends) with the ignorance of birth and name.' 3

\begin{tabular}{l|l}
1 Manu, ix. 186. & 3 Manu, v. 60. \\
2 Manu, iii. 5. &
\end{tabular}

All are Sapindas who offer the cake to the same Chap. III. ancestors.

Four gene

The head of the family would himself offer or $r$ share in share with all his descendants in the offering of the the cakeone cake to his great-grandfather, his grandfather, and his father. And if this passage is taken in conjunction with the one quoted just above, the number sharing in the cake-offering, limited as in the text at the seventh person from the first ancestor who receives the cake, is just sufficient to include the greatgrandson of the head of the family, supposed to be making the offering.

The group, thus sharing the same cake-offering, would in the natural course be moving continually downwards, generation by generation as the head of the family died, thereby causing the great-grandfather to pass from the receivers of the cake-offering to the receivers of the water libation, and admitting the great-grandson's son into the number of Sapindas who shared the cake-offering. And at no time would more than four generations have a share in the same cake offered to the three nearest ancestors of the head of the family.

The Samānodakas, or pourers of the water libation similar appear to have been similarly grouped. $\quad \begin{gathered}\text { grouping } \\ \text { of the }\end{gathered}$

'Ignorance of birth and name' was in Wales pourers of considered to be equivalent to beyond fifth cousins. libation. According to the Gwentian Code, "there is no proper name in kin further than that'-i.e. fifth cousins. ${ }^{1}$ And this tallies exactly with the previous quotation from Manu limiting the water libation to 
Crap. III. three generations of ancestors beyond those to whom the cake is due, which, as has been seen, includes fifth cousins.

And it must be borne in mind that fifth cousins are great-grandsons of the great-grandsons of their common ancestor, or two generations of groups of second cousins.

The oinos It was extremely improbable that a man would
includes four gene- see further than his great-grandchildren born to him rations. before his death. And it might also occasionally occur in times of war or invasion that a man's sons and grandsons might go out to serve as soldiers, leaving the old man and his young great-grandchildren at home.

If the fighting members of the family were killed, the great-grandsons (who would be second cousins or nearer to each other) would have to inherit directly from their great-grandfather: and thus, especially in cases where the property was held undivided after the father's death, we can easily see that second cousins (i.e. all who traced back to the common great-grandfather) might be looked upon as forming a natural limit to the immediate descendants in any one oikos, and as the furthest removed who could claim shares of the ancestral inheritance.

After the death of the great-grandfather or head of the house, his descendants would probably wish to divide up the estate and start new houses of their own. The eldest son was generally named after his father's father, ${ }^{1}$ and would carry on the name of the eldest branch of his great-grandfather's house, and Crap. III. would be responsible for the proper maintenance of the rites on that ancestor's tomb. He would also be guardian of any brotherless woman or minor amongst his cousins, each of whom would be equally responsible to him and to each other for all the duties and privileges entailed upon blood-relationship.

Thus seems naturally to spring up an inner group of blood-relations closely drawn together by ties which only indirectly reached other and outside members of the $\gamma^{\prime}$ voos.

In the fourth century B.c. this compact group the limited to second cousins still survived at Athens, at athens. responsible to each other for succession, by inheritance or by marriage of a daughter; for vengeance and purification after injury received by any member, and for all duties shared by kindred blood.

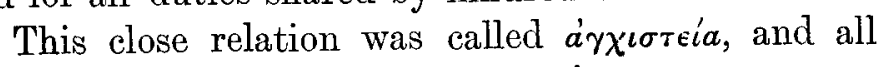
its members were called ár $\chi \iota \sigma \tau \epsilon i s$, i.e. any one upon whom the claim upon the next-of-kin might at any time fall.

The speech of Demosthenes against Makartatos affords considerable information as to the constitution of the family-group or oikos. The five sons of Bouselos, ${ }^{1}$ we are told, on his death divided his substance amongst them, and each started a new oikos and begat children and children's children. ${ }^{2}$ The action, which was the occasion of the speech, lay between the great-grandsons of two of these five founders of oiko, Stratios and Hagnias, and had reference to the disposal of the estate of the grand-

\footnotetext{
1 Cf. infra, tree on p. $63 . \quad \mid \quad 2$ Dem. c. Makart. $105 \check{-}-6$.
} 
Crap. III. son of the latter, which had come into the hands of the great-grandson of Stratios.

One might have supposed that the descendants of Bouselos, with their common burial ground ${ }^{1}$ and so forth, would have ranked as all in the same oikos under their title of Bouselidai. But it is clear from this speech of Demosthenes, that too many generations had already passed to admit of Bouselos being considered as still head of an unbroken oîsos, and that his great-great-grandsons were subdivided into separate oisco under the names of their respective

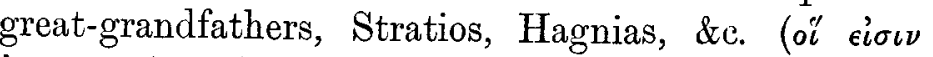

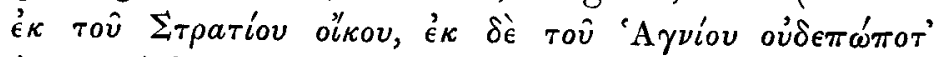
'่' $\left.{ }^{\prime} \nu O \nu \tau o\right) .{ }^{2}$

\section{§ 2. LIMITATIONS IN RESPECT OF SUCCESSION} OUTSIDE THE DIRECT LINE OF DESCENT.

The right

The Gortyn law quoted above in the previous section goes on :-

\begin{abstract}
v. 'If (a man or woman die and) they have no children, the deceased's brothers and brother's children or grandchildren shall have the property. If there are none of these, the deceased's sisters, their children or grandchildren. If there are none of these, to whom it descends of whatever grade they be, they shall inherit the property.
\end{abstract}

This clause takes the evidence one step further, and it is noticeable how the right of inheritance is determined by the great-grandchild of the common ancestor. In the direct line, a man's descendants

\footnotetext{
1 Dem. c. Makart. $1077 . \quad$ | $I d .1078$ et seq.
}

down to his great-grandchildren inherited his estate. Crap. III. In dealing with inheritance through a brother of the deceased the heirship terminates with the grandchild of the brother, who would be great-grandchild of the nearest common ancestor with the previous owner of the estate. If there is no brother, the child of the cousin limits the next branch, as will be seen,

Isaeus ${ }^{1}$ describes the working of the then-existing The law (c. 350 B.c.) law of inheritance at Athens as follows :- - to Isaeus.

The law gives 'brothers' property' (i.e. property without lineal succession) to

1. Brothers by the same father, or brother's children, for these are related to the deceased in the nearest degree;

2. Sisters by the same father, or sister's children;

3. First cousins by the father's side as far as

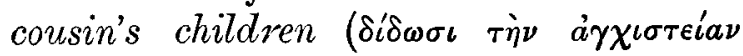

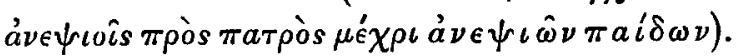

Failing these, recourse is had back again into

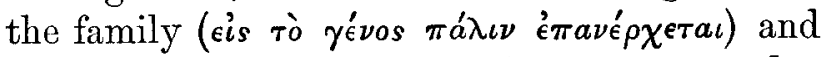
the law makes those related through the mother of the deceased, masters ( $\kappa \dot{v} \rho \iota^{\prime}$ ) of the family (and inheritance) in the same order as on the father's side from the beginning.

That is to say, failing first cousins once removed, the inheritance goes back and begins again at the mother of the deceased, who however, being a woman, can only inherit on behalf of her issue, present or prospective. ${ }^{2}$ If she has married again and has a son (half-brother to her deceased son) he would inherit. Failing her issue, her brother and so on to first cousin's children

\footnotetext{
1 Isaeus, vii. 22, and xi. i. | $\quad{ }^{2}$ Isaeus, xi. 30.
} 
Crap. III. of the deceased, through his mother, would have the inheritance.

Failing these, the nearest kinsman to be found on the father's side, of whatsoever degree, is to inherit.

The law

to Demo-

The law as stated by Demosthenes ${ }^{1}$ coincides with this :- -

'If there are no sons, brothers by the same father (shall inherit) : and their true born children, if there are any, shall have the share of their father: if there are no brothers or brother's children the issue of the latter in the same way shall partake : males and children of males shall have preference (over females) if they are born of the same (parents), even if they are further off by birth ( $\gamma^{\prime} \dot{\nu \epsilon \iota}$ ) [i.e. are a generation lower down]. If there are none on the father's side as far as cousin's children ( $\mu \epsilon \chi^{\prime} \rho \iota \dot{a} \nu \epsilon \psi(\hat{\omega} \nu \pi a i \delta \omega \nu)$, the relations on the mother's side in the same way shall have possession (kvpious eival). But if there are none on either side within these degrees, the nearest of kin on the father's side shall have possession.'

Whenever this law is quoted the limit of relation-

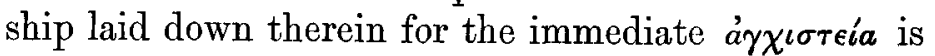
always that of $a \nu \epsilon \psi(\hat{\omega} \nu \pi a \hat{a} \delta \epsilon s$, or sons of first cousins, who inherit from their first cousins once removed (oncle à la Brétagne, or Welsh uncle as this relation has been called). Occasionally the patronymic form à $\in \psi\llcorner a \delta o \hat{\imath}$ is used, apparently with the same significa-

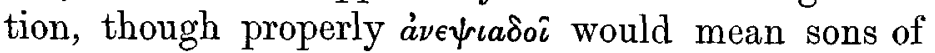
two first cousins, i.e. second cousins. ${ }^{2}$

It appears from the evidence reviewed hitherto, that any great-grandson could inherit from any grandson of a common ancestor, and the conclusion

\footnotetext{
I c. Makart. 1067.

${ }^{2}$ In Dem. c. Leochar. 1088

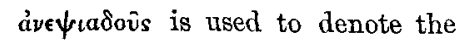
relationship of a man to the adopt-

ed son of his great-uncle, or, as we should say, first cousin once removed.
}

also seems to be justified, that the group of great- Chap. III. grandsons were considered to divide up their right to greatinherit once for all, and that having done so, with grandsons. respect to that inheritance they were considered to have begun a new succession. To put it differently, in case of the death of one of these second cousins, after the final division of their inheritance had taken place, the rest of the second cousins would have no right to a share in his portion; an heir would have to be found within his nearer relations. Thus, they share responsibilities towards any of their relations within the group and higher up in their families, and also stand shoulder to shoulder in sharing such burdens as pollution and so on, but are outside the immediate a ${ }^{\prime} \gamma \chi \sigma \tau \tau i \boldsymbol{a}$ with respect to each other's succession. The reason for this will perhaps be more apparent as the argument proceeds.

That the grandson of a first cousin was outside the ary $x^{\imath \sigma \tau \varepsilon i a}$ is clear from the speech of Demosthenes already mentioned, ${ }^{1}$ where the plaintiff, who originally stands in that relationship to the deceased whose inheritance is in dispute, is adopted as son of his grandfather (first cousin of the deceased), in order to come within the legal definition of

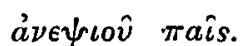

That the son of a second cousin was also without the pale is directly stated in several passages in Isaeus.

It must be remembered that by 'inheritance' is The heir meant the assumption of all the duties incumbent on ${ }_{\text {ranked as }}^{\text {always }}$

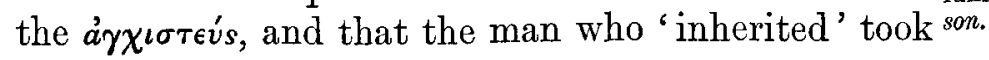


Crap. III. his place for the future as son of the deceased in the family pedigree, and reckoned his relationship to the rest of the $\gamma$ f́vos thenceforth from his new position, in the house into which he had come. ${ }^{1}$

Hence the Now if it is true that to the great-grandson was the in- the lowest in degree to which property could directly heritance, descend without entering a new oisos, and if that children. great-grandson was also looked upon as beginning with his acquired property a new portion of the continuous line of descent; any one, who 'inherited' from him and ranked in the scale of relationship as HIS sON, would necessarily fall outside the former group and would be considered as forming the nearest relative in the next succeeding group. This, it seems, is the meaning of the language of the law which limits the ary ${ }^{\prime \sigma \tau \tau \epsilon i a}$ to the children of first cousins who could inherit from their parent's first cousins, and still retain their relationship as great-grandsons of the same ancestor. Whereas any one taking the place of son to his second cousin would be one degree lower down in descent, and pass outside the limit of the four generations. The law makes the kinsmen therefore exhaust all possible relationships within the group by reverting to the mother's kindred with the same limitation before allowing the inheritance to pass outside or lower down.

Disin- In confirmation of this view the following passage heritance may be quoted from Plato's Laws :-
must be

sanctioned

by kins-

'He who in the sad disorder of his soul has a mind, justly or unjustly, to expel from his family a son whom he has begotten and brought up, shall not lightly or at once execute his purpose ; but

1 Dem. c. Makart. and c. Leoch. 1100, \&c. first of all he shall collect together his own kinsmen, extending to CHAP. III. (first) cousins ( $\mu$ '́ $\chi \rho \iota$ à $\nu \epsilon \iota \hat{\omega} \nu$ ), and in like manner his son's kinsmen by the mother's side, ${ }^{1}$ and in their presence he shall accuse his son, setting forth that he deserves at the hands of them all to be dismissed from the family ( $\left.\gamma^{\prime} \in \mathbf{\nu O s}\right) .^{2}$

Before dishonouring one of the family and so bereaving it of a member owing duties which, by his disinheritance, may fall into abeyance or be neglected, the parent calls together all to whom his son might perhaps ultimately become the only living representative and heir, and who might at some future time be dependent on him for the performance of ancestral rites. That this was in Plato's mind when he wrote is shown by the next sentence, in which he provides for the possibility of some relation already having need of the young man and being desirous to adopt him as his son, in which ease he shall by no means be prevented. The concurrence of all relations in such a position was therefore necessary.

In other cases where Plato mentions similar gatherings of the kin but for different purposes, he extends the summons to cousin's children. But here it can be seen they would have no place. They would be second cousins to the disgraced youth ; they might have to share privilege or pollution with him, but had no claim on him for duties towards themselves. He would be 'cousin's son' to his father's first

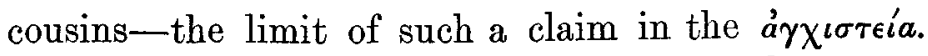

In the speech of Isaeus concerning the estate The case of Hagnias, a real second cousin is in possession of estate of the estate. He won the case at the time and died in Hagnias

1 The wife's kin are no kin to her husband, but are to her son. Jowett. 
Снар. III. possession, and an action against his son Makartatos in Isaeus for the same property is the occasion of one of the Demo- speeches of Demosthenes. To fully understand the sthenes.

relationships referred to in these cases, the accompanying genealogical tree of the descendants of Bouselos may be of assistance. It will also serve as an example of how a kindred hung together, and how by intermarriage and adoption the name of the head of an oikos was carried on down a long line of male descendants.

Theopompos, in the speech of Isaeus, had taken possession of the estate of his second cousin Hagnias, as his next of kin and heir. Throughout the speech

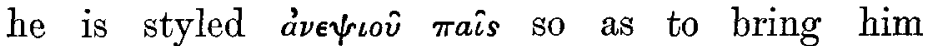
within the phraseology of the law, and he successfully defends himself from the claims of the next generation below-viz., his brother's son. But in the speech of Demosthenes against his son Makartatos, who had taken possession at his father's death of the disputed property, it is represented that his father had got possession only by defeating another claimant, Phylomache II., by 'surprise,' as it was called, by stating that her grandmother through whom she traced her claim was only half-sister to Hagnias' father. But Phylomache's husband, having caused their son Euboulides III. to be adopted as the son of Euboulides II.- - his wife's father and Hagnias' first cousin, a quite regular course for the grandson inheriting through his heiress mother-proved that his wife's grandmother was whole sister to Hagnias father, and brought the action under the guidance of Demosthenes against Makartatos. This Euboulides

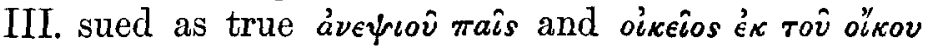

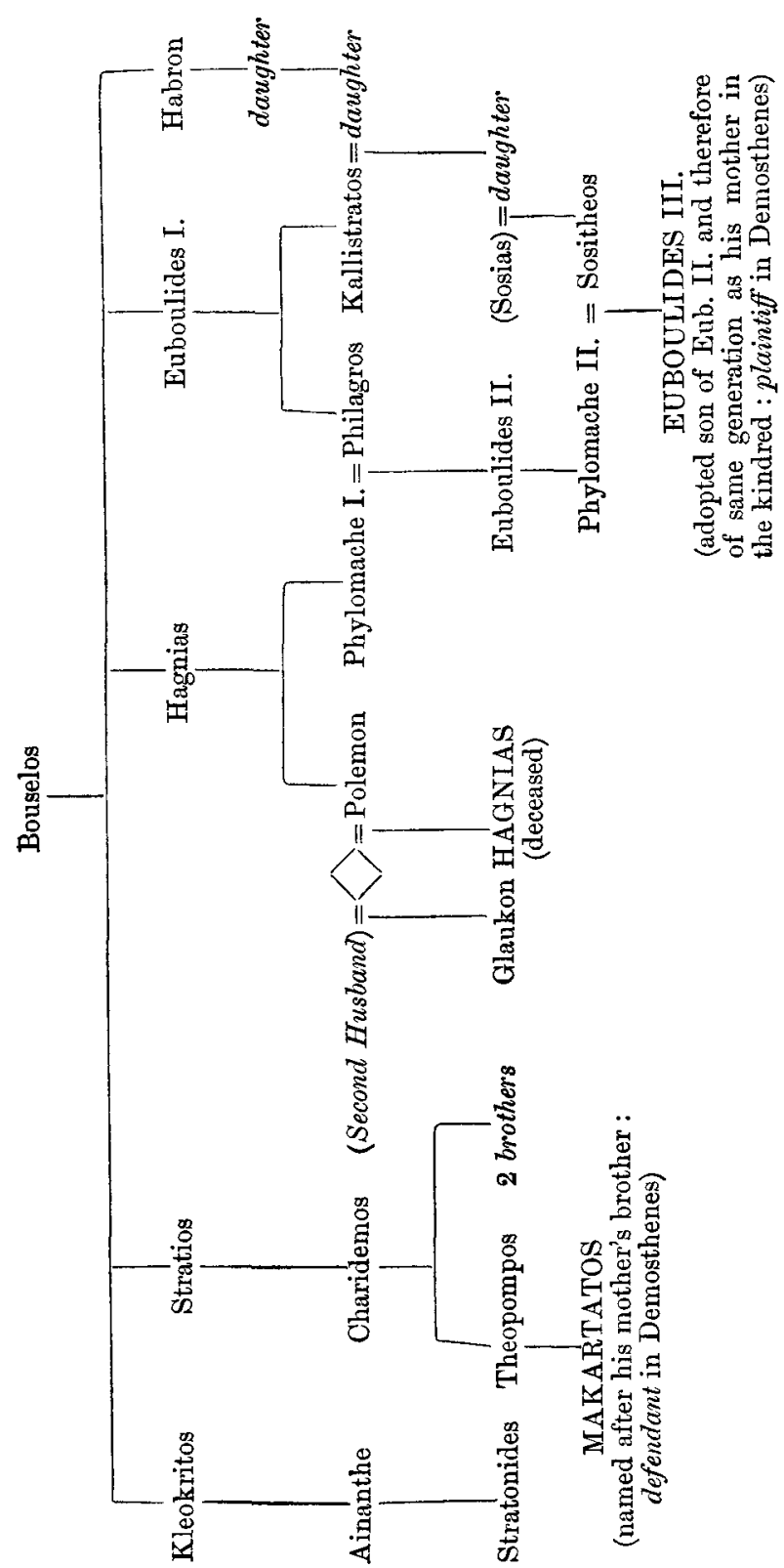

Chap. III. 
Crap. III. of Hagnias. ${ }^{1} \mathrm{He}$ is described as having 'one of the titles mentioned in the law as far as which the law

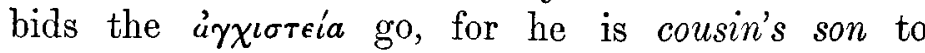
Hagnias.'

On the other hand, Theopompos, father of Makartatos and second cousin of Hagnias, is mentioned ${ }^{2}$ as 'being of a different oîsos altogether,' and not at all related in such a way as to be heir of

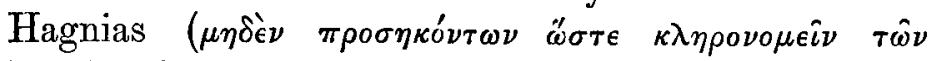

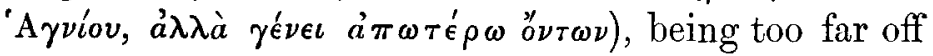
in the family (or by birth).

That the title of Theopompos (viz., second cousinship) was not valid, may be inferred partly by the ruses he adopted to get possession, but more especially by the fact ${ }^{3}$ that none of the other second cousins on a par with him, and with whom he ought to have shared, seem to have believed in the validity of their titles, or at any rate taken the trouble to sue for part of the estate.

However this may be, there does not seem anything in these speeches other than confirmatory of the view stated above of the composition and

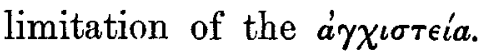

\section{§3. DIVISION AMONGST HEIRS.}

Succession to the inheritance of an estate was ordained by law in strict accordance with the ancient conception of the unity of the family. On the death of the head of a family, unless the paternal oiros was

\footnotetext{
1 Dem. c. Makart. 1058

$21 d .1070$.

3 Mentioned in Dem. c. Makart. 1056.
}

voluntarily continued unbroken by his descendants, СнAp. III. the natural course was for each son ultimately to live apart and found a separate oînos consisting of himself and his offspring. Equal division amongst heirs was therefore the rule in Greece; equal division, that is to say, between all of equal grade.

The Gortyn Laws have already been referred to as enforcing the principle. ${ }^{1}$ If a man died, his heirs were either his sons, or his grandsons, or his greatgrandsons. If he had no children, his brothers, and their children, or their grandchildren succeeded.

The Athenian law was conceived in the same The share spirit, but mentions a further point-viz., that in the of a dead division amongst sons, the oikos of any one of their by his number who had died before the division, could be represented by his sons or grandsons, who thus received their father's share.

This system of representation probably existed also among the Gortynians, though no mention of it is made in their laws, for it is inconceivable that any of the grandsons could be deprived of all share in their grandfather's estate by the mere death of the intermediate generation.

But the division per stirpes was not maintained throughout. It is probable from the words of the Attic orators that equal division amongst all of the same grade, such as nephews or cousins, took place per capita, any deceased member of that grade being represented by his sons. Representation, of course, could not take place in the case of a division amongst cousins' sons, owing to the strict limitation of the
1 Supra, p. 56. 
Chap. III. áy $\chi \boldsymbol{i \sigma \tau e i a}$ to four generations from the common ancestor; any deceased relation in that degree therefore simply dropped out of the succession.

If sons all It has generally been assumed that grandsons dead,
grandsous inheriting directly from their grandfather, all the probably intermediate generation being already dead, inherited per capitu, none the less the shares of their respective fathers per stirpes. But if the foregoing account of the unity of the oikos and its resemblance in its composition to the household of the Welsh tribal system be correct, it seems more reasonable to suppose that, all the intermediate generation being dead, the grandsons, in virtue of being all equally related to their grandfather, would inherit in equal shares per capita. Any dead grandson would of course be represented, as before, by his son or sons.

The evidence is not sufficient to justify more than a suggestion on either side with regard to divisions amongst lineal descendants. With regard to successions by relations outside of the direct line of descent, such as nephews or cousins, it is almost certain that all of the same degree took equal shares per capita.

Following the law for daughters, quoted by Demosthenes ${ }^{1}$ - viz., that though all shared the inheritance of the property, only one need be dealt with in view of securing the succession-the assumption can be made that, when there were several heirs related in the same degree to the former owner of the estate, one of their number would be set apart to continue the household of their kinsman as his son, whilst the

\footnotetext{
1 c. Makart. 1068, supra, p. 26
}

others merely took their shares of the property Chap. III. divided to continue their own oiko respectively.

The equal division of inheritance amongst kinsmen of equal degree per capita, in combination with the system of representation above described, is entirely consistent with the tribal conception of the household as hanging closely together, its members always looking up to their venerable head, in whom the ownership of the property vested, until by the death of older generations and the consequent subdivision, each in his turn became head of an oikos and owner of its share in the ancestral property.

\section{QUALIFICATIONS FOR THE RECOGNITION OF TRIBAL BLOOD.}

IT has been remarked above with what jealousy Purity of the purity of the blood of the community was blood guarded. No child was admitted into the kindred of jealously its father until all concerned were fully convinced of the blamelessness of its pedigree. In such circumstances it was no easy matter to acquire the privileges attached to the possession of tribal or citizen blood. It seems to have been considered that however great otherwise the claims of a stranger might be, time alone could really render the qualifications of his family complete.

Under the ancient Laws of Wales no stranger's In Wales, family could acquire the full privileges of a Welsh artained in tribesman or Cymro, as regards location on land, the fourth until after many generations. But if they married by interWelshwomen, and held land from generation to gener- marriages. 
Crap. III. ation, the greatgrandsons became fully privileged tribesmen. ${ }^{1} \quad$ Similarly if a stranger voluntarily assumed the position of serf to a Welshman, and his descendants did not choose to depart, but remained in that position to the descendants of the Welshman, the greatgrandsons of the Welshman became proprietors of the greatgrandsons of the stranger. ${ }^{2}$

otherwise But for the stranger who merely resided in Wales not until and did not marry into any Welsh tribe the period genera- of probation was three times as long-viz., the greatgrandson of the greatgrandson of his greatgrandson was the first to attain to full tribal privilege-

'Strangers and their progeny are adjudged to be aillts; also a reputed son who shall be denied and his progeny, and evildoers of federate country and their progeny, unto the end of the ninth descent.' $^{3}$

i.e., the tenth man would no longer be reckoned an aillt but a free Cymro.

The issue of a stranger obtains the privilege of a tribesman in the fourth person by legitimate marriages. ${ }^{4}$ But the aillt or stranger, who dwells in Cymru, does not attain until the end of the ninth descent.

So too inversely:-

The title to inherit by kin and descent in the tribal land and rights of his ancestors does not become extinct till the ninth man. The ninth man in descent from a banished tribesman coming home and finding his title as representative of his family seemingly

1 Welsh Laws, iv. i. and x. Vened. Code, ii. xvi. and elsevii. Exception is made for the where. son of a stranger chieftain.

${ }_{2}$ Welsh Laws, v. ii. and ${ }^{4}$ Welsh Laws, xiii. i. extinguished, is to raise an outery that from a Chap.III. proprietor he is becoming a nonproprietor, and the law will shelter him and adjudge him an equal share with the occupants he finds on the land. This is called the 'outcry across the abyss.' 'The tenth man's outcry cannot be heard. 'Others say' that the ninth man is too late to raise the cry. ${ }^{1}$

This is exactly parallel to the case of the stranger resident in Cymru. For nine generations he is a stranger, and in the tenth a Cymro. Here for nine generations is the Cymro abroad a tribesman, and in the tenth he is a stranger.

From a passage in Deuteronomy it would appear The same that the qualifications for admission as a full tribes- ${ }_{\text {amongst }}^{\text {rule }}$ man amongst the Israelites were identical with those ${ }_{\text {ites }}^{\text {thrael }}$ just mentioned.

The Israelites had purified themselves of the ancestor worship, that so long survived in Greece, and had, if one may say so, amalgamated all their minor deities and tribal superstitions in their one great monotheistic religion. Even then their tribal minds could not carry back their theology behind the known history of their own ancestors. Their God was the God of Abraham, Isaac, and Jacob, and was in their conception the greatest of Grods-i.e., greater than the Gods of other peoples, the existence of which their own beliefs did not preclude. Thus where in Attic writers we have mention of the religious rites of the family (which a stranger or polluted man might not

1 Venedotian Code, ii. xiv. and for restoration of her house and Gwentian Code, ii. xxx. Cf. the fields after an absence of seven Shunammite's cry unto the King years. 2 Kings viii. 3. 
Crap. III. approach), and of the partaking therein as proof of the whole admission and pure blood of those present, so in Deuteronomy the expression 'the Congregation of the Lord,' is used to denote that sacred precinct, forbidden to all save pure tribesmen of Israel.

It may be inferred from the following passage that if a stranger resided in Israel, and his family continued to do so for nine generations, the tenth generation would in any ordinary case be admitted to the Congregation of the Lord as full Israelites.

Deut. xxiii. 2 and 3. 'A bastard, or an Ammonite, or Moabite shall not enter into the congregation of the Lord even to their tenth generation, for ever.'

In special cases (exactly as was the rule in Wales)-such as the Edomite who was partly akin already, and the Egyptian who was united to the Israelites by the mysterious bonds of hospitality-a shorter sojourn in the land was held to qualify for full tribal privilege.

Deut. xxiii. 7 and 8. 'Thou shalt not abhor an Edomite, for he is thy brother: thou shalt not abhor an Egyptian, because thou wast a stranger in his land. The children that are begotten of them shall enter into the congregation of the Lord in their third generation.'

The third generation of children would be the greatgrandchildren of the original settler, and this is just one third of the length of time implied as required from the ordinary stranger, who only attained the tribal privilege in the third succession of greatgrandchildren.

It is worth notice in this connection that the land of Canaan was divided up in the names of the greatgrandchildren of Abraham, to whom the promise was

made; Ephraim and Manasseh, the sons of Joseph, Crap. III. taking their place amongst the others by adoption as sons by their grandfather Jacob, on an equality with his other sons. ${ }^{1}$

These rules are not to be found with the same The prividistinctness surviving at Athens, but there is a good citizenship deal of evidence showing how jealously the introduc- jealously tion of strangers to citizenship-which retained much Athons. that made it the later equivalent of the tribal bondwas regarded.

Strangers made citizens (formally, ceremoniously, and by public vote) by the Athenian people cannot hold office as archon or partake of a holy office

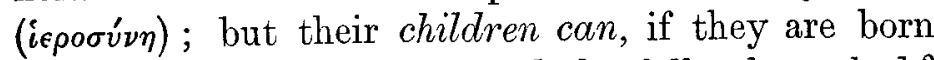
from a citizen wife duly and lawfully betrothed. ${ }^{2}$ That is to say, that the Athenians considered it necessary that there should be actually citizen blood in the veins of all who held office amongst them. ${ }^{3}$

The abhorrence in which the introduction of alien Abhorblood was held is illustrated by the Athenian law ${ }_{\text {alien }}^{\text {rence }}$ concerning marriage with aliens, quoted by Demos-blood. thenes in his speech against Neaera.

' Law: If an alien shall live as husband with an Athenian woman by any device or contrivance whatever, it shall be lawful for any of the Athenians who are possessed of such right, to indict him before the judges. And if he is convicted, he shall be sold for a slave and his property confiscated, and the third part shall belong

1 Gen. xlviii. 5. $C f$. Pindar, Ol. viii. 46. Troy to be subdued by children of Aeacus in first and fourth generations.

2 Dem. in Neaer. 1376.
3 Anc. Inserip. Brit. Mus. ccxxxviii. Citizenship had to be confirmed on son of foreigner admitted to citizenship. 
Crap. III. Halikarnassos ${ }^{1}$; and some similar rule seems to have

held good among the Jews.

'These sought their register among those that were reckoned by genealogy, but it was not found ; therefore were they, as polluted,

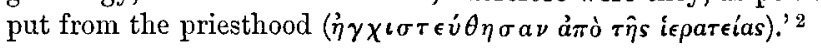

The book of Nehemiah closes with the triumphant verse: 'Thus I cleansed them from all strangers.'

The rule in the Ordinances of Manu for the recovery of Brahman caste is just halfway between the tenth and the fourth generations-namely, the seventh, or greatgrandson of the greatgrandson of the first halfcaste. This is only the case when each generation marries a Brahman wife.

'If (the caste) produced from a Brahman by a Çudra woman keeps reproducing itself by nobler (marriage) this ignoble attains a noble family at the seventh union (Yuga). ${ }^{3}$

\section{Thus :- -}

If (1) the halfcaste marries a Brahman woman and

(2) his son ...... do.

(3) . grandson . . . do.

(4) . greatgrandson ... do.

(5) his son . . . . . . do.

(6). . grandson . . . . do.

(7) . greatgrandson . . . do.-at last his family is restored to their lost high caste.

1 Handbuch der Griechischen Staatsalterthümer, von G. Gilbert, ii. p. 298, quotation from Ditten-

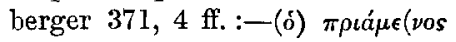

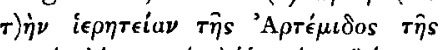
$\Pi \epsilon \rho(\gamma a)$ ías $\pi(a \rho) \epsilon^{\prime} \xi \epsilon \tau a(\iota \quad i) \epsilon \rho \epsilon \iota \nu$

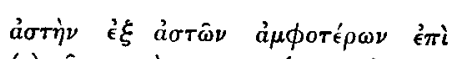

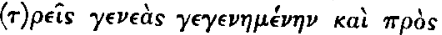

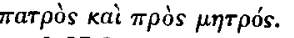

2 Nehemiah vii. 64

3 Manu, x. 64.

\section{$\S 5$. LIMITATIONS OF LIABILITY FOR BLOODSHED.}

THE ar $\chi \iota \sigma \tau \epsilon i a$, limited to relations within the All within same degrees as for other purposes, seems to be the the a a $x_{\tau \in \text { ia }}$ unit in the case of pollution of the kindred by the liable. death-violent or natural-of one of their number.

1 'Whosoever being related to the deceased on the male or

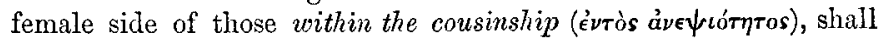
not prosecute the murderer when he ought and proclaim him outlaw, he shall take upon himself the pollution and the hatred of the gods ... and he shall be in the power of any who is willing to arenge the dead ...?2

'The pollution cannot be washed out until the homicidal soul which did the deed has given life for life and has propitiated and laid to sleep the wrath of the whole family' $\left(\xi v \gamma \gamma^{\prime} v \epsilon \iota a\right) .^{3}$

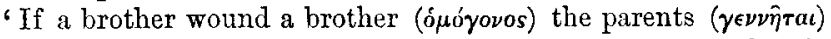
and the kinsmen ( $\sigma v \gamma \gamma \in \boldsymbol{\nu} \in \hat{i s}$ ) to cousins children on male and female side shall meet and judge the case.' 4

Ransom was forbidden; citizen was bound to citizen with ties that had inherited too much of the tribal sanctity to admit of any extenuation of the extreme penalty.

It was no doubt a wise policy on the part of the legislators, with the view to the preservation of respect for life and property, to make the responsibility for murder rest as widely as possible, and include as many relations and connections on both sides as might be. In order also that the wife, in case her husband was killed, and the daughter, in case her father was killed, might be fully protected and represented

\begin{tabular}{l|l}
1 Plato's Laws, ix. 871 в. & $\begin{array}{l}3 \\
2\end{array}$ \\
2 Cf. 868. & $878 \mathrm{D}$.
\end{tabular}


CIIAP. III. among the prosecuting kindred, the law of Draco seems to lay the necessity for action also on the father-in-law and the son-in-law. The phratria, being such a compact organisation and exacting such formal admission of its members, would naturally be concerned to see that justice was dealt to any of its number. Though we cannot include the phratores amongst those directly responsible equally with the near kinsmen for crimes committed by one of their number, they would always have to take a certain part in whatever was necessary to bring him to justice, besides being generally concerned in all matters relating to kinship, which affected any member of their phratria.

'Proclamation shall be made against the murderer in the agora within [? his] cousinship and (the degree) of a first cousin, and prosecution shall be made jointly by cousins and cousins' children and descendants of cousins, and sons-in-law and fathersin-law and phratores.'

That Demosthenes here quotes a genuine law of Draco is proved by an inscription found at Athens belonging to the year 409 B.c., recording this sentence as part of the law of Draco about murder. ${ }^{1}$

In another place Demosthenes thus refers to the action of this law :-

'The law commands the relations to go forth and

\begin{tabular}{|c|c|}
\hline 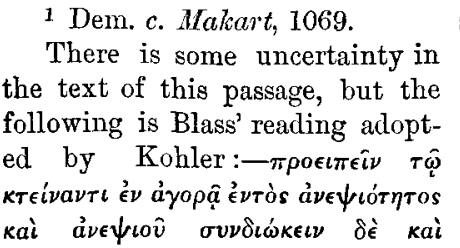 & 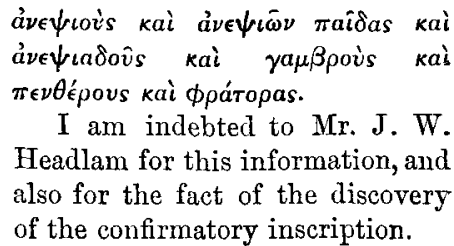 \\
\hline
\end{tabular}

prosecute as far as descendants of cousins ; and in the CHAp. III. oath it is defined what the relationship actually is, ete.' ${ }^{1}$

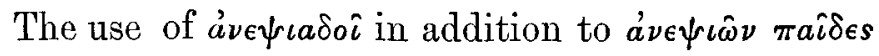
in Draco's law above is emphatic as implying that as regards pollution the group of relations to second cousins were treated en masse as under the stain; they had not yet, so to speak, reached the point where they could divide up their responsibility.

If the murder was committed within the narrow The case limits of the a' $\gamma$ ¿

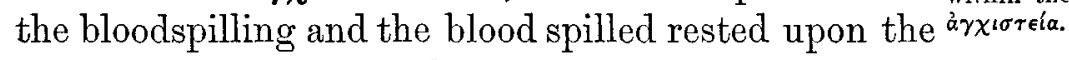
whole group with overwhelming force.

Plato ${ }^{2}$ treats of such a calamity and prescribes the remedy. If a man slay his wife, or she her husband, his children are orphans; their debt of maintenance to their parent is cancelled; he must flee; they possess his goods. If he is childless, his relations shall meet to the children of his cousins on the male and female side (i.e. all his possible heirs) and shall elect not one of themselves, but a younger son of some other and pious family to bring in new blood with better fortune to counteract

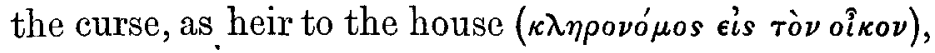
introducing him to the father of the banished (or deceased) man and to those further back in the family

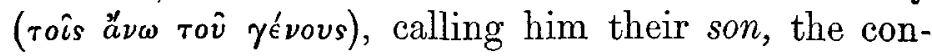
tinuer of their family ( $\left.\gamma e v \nu \eta^{\prime} \tau \omega \rho\right)$, their hearth-keeper

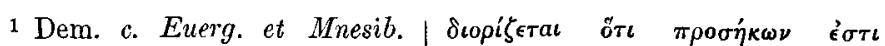

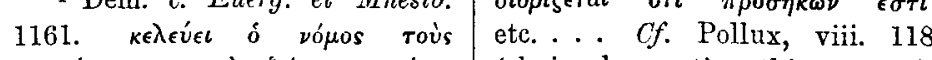

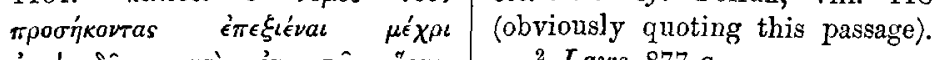

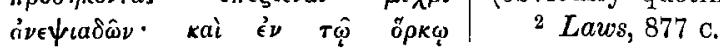




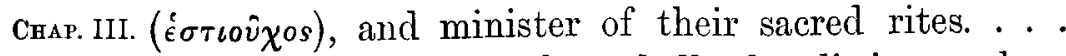
But the guilty man they shall 'let lie,' nameless, childless, portionless for ever. ${ }^{1}$

The blood. In the ancient Laws of Wales the blood-fine takes fine or a very important position. But whereas all the Wales. relations of the murderer are liable to be called upon to pay the 'Spearpenny,' as it is called, only the inner kindred within fixed degrees contribute proportionally to the payment of the price. The group upon which this responsibility falls is twice as large in the Welsh Laws as at Athens, and includes fifth cousins, or the greatgrandchildren of greatgrandchildren of a common ancestor.

The Dimetian Code describes the relations who pay galanas as follows." Those beyond only pay 'spearpenny.'

Father and mother.

Grandfather.

Greatgrandfather.

Brother and sister.

First cousins.

Second cousins.

Third cousins.

Fourth cousins.

Fifth cousins.

According to the Gwentian Code, fifth cousins share. 'There is no proper share, no proper name in kin further than that.' 3

1 Cf. 2 Sam. xiv. 7. House Sapinda and Samānodaka: both extinguished for fratricide.

2 Dimetian Code, ii. i. owe rites at death of kinsman.

3 Gwentian Code, ii. viii. Cf. above.
The Venedotian Code states that galanas is paid by CHAP. III. the kindred: two parts by the relations of the father, one part by the relations of the mother, to sixth cousins. All kindred after sixth cousins pay spearpenny. ${ }^{1}$

The sixth cousin is also called ' kinsman son of a fifth cousin, and then the father (i.e. the fifth cousin) pays it, because his relationship can be fixed, but the relationship of his son to the murderer cannot.'

The defilement of carrying out a corpse and Defileassisting at a funeral also covered the same area of ${ }_{\text {rested }}^{\text {ment }}$

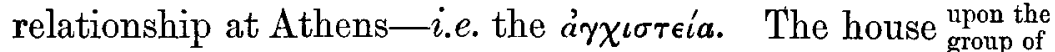
of the dead man was only to be entered by those kinsmen. naturally polluted.

'After the funeral no woman to enter the house save only those defiled; to wit-mother, wife, sisters, and danghters; beside these not more than five women and two girls, daughters of first cousins : beyond these, none.' 2

Demosthenes quotes the law of Solon to the effect that-

'No woman under sixty years old to enter the house or follow

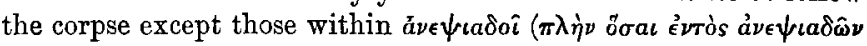
$\epsilon i \sigma(\nu)$ : no woman at all may enter the house after the carrying

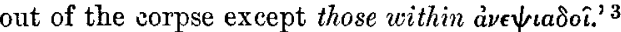

All those near of kin assist in the funeral.

The payment of the blood-fine by the whole family of the murderer was considered necessary to

\footnotetext{
1 Venedotian Code, iii. i. Fifth century B.c. Cf. Numbers

2 Inscript. Jurid. Grecques par xix. 14. Dareste, \&c., 1891, p. 10. In- $\quad 3$ c. Makart. 1071. scription found at Inlis in Keos.
} 
Crap. III. allay the vengeance and anger of the family of the murdered man within the same area of relationship. In Wales the members of the family who received the galanas, did so in proportion to the importance of their position in the transmission of the kindred blood, according to a classification identical with their proximity in relationship to the dead man, and their expectation of inheritance from him or succession to his place.

The inclusion of the mother's relatives and their liability in these circumstances, in addition to the paternal relations, follow naturally enough in Wales as in Greece when once the transmission of inheritance through a woman, in default of male heirs, had become a recognised possibility. A woman's sons might always be called upon under certain circumstances to take inheritance from her father or next of kin. They therefore quite fairly shared in the claims as well as the privileges of their position. And vice versa, in exchange for the priceless guarantee of continuity provided by a woman's offspring to her relations, they too would be prepared to undergo a part of the penalties incurred by any of those who might rank some day as their next of kin, or as their sons.

This view of the source of their recognition as members of the kindred responsible for the blood-fine in Wales is confirmed by a statement in the Venedotian Code. ${ }^{1}$ Those women and clerks who can swear that they will never have children, and so are useless for the preservation of continuity in the

1 Welsh Laws, vol. i. 229. Cf. of those incapable of receiving Ord. of Manu, ix. 201, where list $\mid$ inheritance includes eunuchs. families to which they belong, are specially exempted Cнar. III. from contribution to the galanas, inasmuch as they have forsworn the privilege of attaining through posterity a share in the immortality on earth of their kindred. 


\section{CHAPTER IV.}

THE RELATION OF THE FAMILY TO THE LAND.

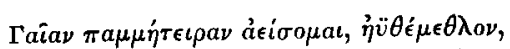

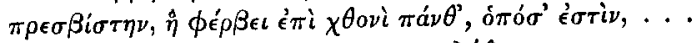

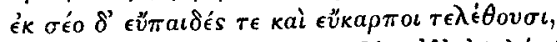

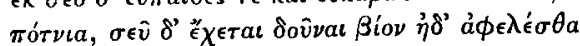

$\theta \nu \eta \overline{r o i s}$ ả $\theta \rho \omega \dot{0} \pi 0 \iota \sigma \iota \nu$.

Homeric Hymn.

\section{§ 1. THE KAHPOE AND ITS FORM.}

CHap. IV. IN trying to realise the methods of land tenure amongst the Greeks, we are baffled by the indirectness of the evidence available.

The usual

We know that the estate which descended from lolding of father to son, and was in theory inalienable from the was called family of its original possessors, was called a $\kappa \lambda \hat{\eta} \rho$ os a ${ }^{k} \lambda \hat{\eta}$ pos or
lot.' or 'lot,' but the familiarity with which the poets, historians, and orators use the word does not afford information as to what the $\kappa \lambda \hat{\eta}$ pos really was and how it was made use of in practice. The law concerning these family holdings, says Aristotle,$^{1}$ and concerning their possible transmission through daughters was not written. It was a typical example of customary law. This statement gives a hint as to the usual treatment of questions arising under this head. Methods of land tenure were not of rapid growth, nor

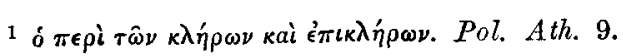

were they easily changed ; they had their source with Crap. Iv. the slow devotion to agriculture of pastoral tribes, and were dependent on a class unaffected by the growth of education and the arts.

The intricate connection of the system of land The relatenure with the composition of the family removed ownershi the consideration of questions of ownership from the of land to sphere of written law, and delegated them to the most ture of the conservative department of customary procedure, ${ }^{\text {family. }}$ ranking them on a par with questions of family religious observances. ${ }^{1}$ The deposit of some ancestor's bones in a certain field was occasionally a valuable link in the title to possession of that piece of land as private property $;^{2}$ and the possession of land at all was in part a guarantee of the pure native blood in the veins of the possessor. ${ }^{3}$ It is a striking illustration of the truth of this that, throughout all the extant speeches of Isaeus dealing with the disposal of $\kappa \lambda \hat{\eta} p o \iota$ of dead citizens, not a single case turns upon evidence for or against a sale or transfer of property. The speeches all deal exclusively with family matters; the line of argument always leads to the proof of near kinship by blood or adoption to the previous owner; and the right of possession of the inheritance seems taken for granted as following incontrovertibly the establishment of the required relationship. ${ }^{4}$

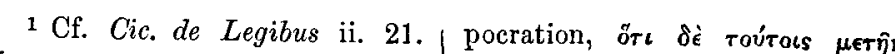

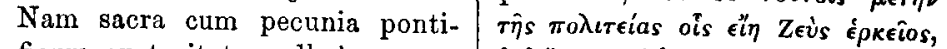
ficum anctoritate, nulla lege conjuncta sunt.

${ }^{2}$ Dem. in Calliclem, 13-14. Coulanges, Problèmes d'Histoire, p. 19.

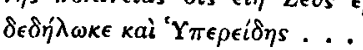

4 In other words, the devisee could not possess the property devised to him until his place as heir in the succession by blood or adoption was legally established. 
Chap. IV. II seems to me that all those who contend for the right of succession to estates, when like us they have shown themselves to be both nearest in blood to the person deceased, and most connected with him in friendship $(\phi i \lambda i a)$, are dispensed from adding a superfluity of other arguments.' 1

In the early settlements, as Thucydides tells us,

necessity was the ruling motive. Each man devoted his attention to providing the necessaries of life. There was superfluity neither of chattels nor of tilth. Men hesitate to sow when the harvest is to be reaped by their enemies. ${ }^{2}$ The flocks and herds of the pastoral tribes could be driven for safety into the mountain strongholds; yet even they were liable to frequent losses. On one occasion Odysseus had to go to Messene 'to recover a debt; which, to wit, the whole people owed him ( $\pi \hat{a} s \delta \hat{\eta} \mu o s)$ : for the Messenians had lifted 300 sheep with their shepherds from Ithaka.' 3 As the newcomers increased in numbers and gained a reputation for ability to defend their own, sufficient to discourage the attacks of their neighbours, they would have leisure to devote some of their energies to the cultivation of the plains around them. Troy was founded first up in the hills, ${ }^{4}$ and afterwards was moved down to a good position on the lower ground for the sake no doubt of the better

\footnotetext{
1 Isaeus, i. 17. The 'friendship' insured that his presence and officiating at the tomb would be acceptable to the soul of the deceased-always an important consideration.

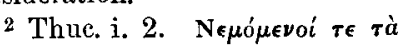

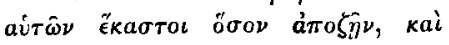

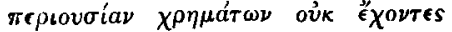

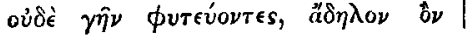

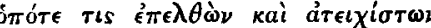

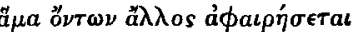

3 od. 21. 16. Cf. 1 l. xi. 682 $s q$. where the booty consists of 50 herds of kine, 50 flocks of heep, 50 droves of swine, 50 flocks of goats, and 150 chestnut mares, many with foals at foot. $1 l . \mathrm{xx}, 216-8$.
}

pasture in the river meadows, and of the agriculture CHAp. IV. which had long been carried on over the 'wheatbearing plain' around the city, ${ }^{1}$ before the ravages of the ten years' war.

It is not proposed to enter in detail into the methods of cultivation of the soil in vogue at various times in Greece; but inasmuch as whilst studying the kernel, assistance may often be obtained from knowledge of the shell, mention may be made in passing of such few points of interest in the physical features of agriculture as may be available.

In the Consular Reports on Land Tenure in Europe Modern made in 1869, descriptions are given of the existing methods of methods of tenure and cultivation in Greece and the tenure in Islands.

In Greece the usual holding of a small proprietor islands. is said to be of fifteen to twenty-five acres (or sometimes double that area), and is called a zeugarion. ${ }^{2}$ Many have only a couple of acres. 'The greatest inconvenience and frequent lawsuits arise from
the manner in which these properties intersect each other. More-
over none of the ustal precautions are adopted to mark the limits
of the different properties, which, in the absence of any reliable
land survey, are often very vaguely described in the title deeds. ${ }^{3}$
In casès of intestacy real property is divided
equally among the children or nearest relatives.
When there is a will the testator can only reserve for
his disposal a share of the estate equivalent to that
which, after an equal division, descends by right to
each of the direct heirs. 
Chap. IV Professor Ansted, in his book on the Ionian Family. Islands in the year 1863, thus describes the manageholdings in Santa ment of an estate on the Island of Santa Maura :-1

'According to Ionian law, all the members of a family share equally in the family property after the death of the father; but it does not follow as a matter of course that the property is divided. It is much more usual that the brothers and sisters, if young, continue to live together till they either marry or undertake some employment or business at a distance. If a sister marries, she is dowered with a sum equivalent to her share. If a brother however earns a separate income, from whatever source, whether he be married or remain single, and whether he live in the same or a different house, or even remove to another town or island, he pays in all his income to a joint fund, the foundation of which is the income obtained from the paternal estate. Those who do nothing else manage the estate. One brother, perhaps, remains in the village as cultivator, another lives in the town acting as factor, or merchant to the estate, receiving and selling the produce and managing the proceeds, whatever the case may be; and in addition selling, exporting, and otherwise conducting a general business in the same department. A third may perhaps receive and sell the goods in a foreign country. A fourth may be a member of the legislature, and a fifth a judge. Some marry and have families, others remain single: but the incomes of all are united, each draws out a reasonable share, according to his needs, and a very close account is kept of all transactions. If one brother dies, his children come into the partnership; and as time goes on, these again will grow up and marry, the daughters receiving a proportional and often large dower out of the joint fund, entirely without reference to the special property of their parents. This may go on indefinitely : but as family quarrels will arise, there are always means of terminating the arrangement, and closing accounts, eithe entirely as regards all, or partially as with reference to a mauvais sujet, or troublesome member of the partnership ... This curious patriarchal system, though obtaining more perfectly and frequently in Santa Maura than in the other islands, exists in Cephalonia and is said to be not quite unknown in Zante, where the state of society approximates far more to that common in the western countries of Europe. Santa Naura, being the most isolated of all the islands and that which retains all ancient customs most

1 P. 199. tenacionsly, is naturally that in which this sort of communism can CH 1P. IV. exist with smallest risk of interference.'

According to the Consular Reports, the relations between landlord and tenant are governed more by local usage than by law, and the landlord generally takes on an average about 15 per cent. of the produce in kind on the threshing-floor, as rent, in cases where he does not supply more than the bare use of the land. ${ }^{1}$

There is little manuring; the light plough barely The open turns the surface of the land. Land is usually allowed fystem in to lie fallow every other year, sometimes two years Greece, out of three. Sheep and goats are the chief stock; they of course graze in summer on the mountains; villages sometimes own forests and waste lands in common.

In the islands of the Archipelago, ${ }^{2}$ the holdings are and in the frequently divided into separate plots consisting of a quarter or half acre apiece or even less, intersected by those belonging to other parties. Cattle are pastured on the fallow, roadsides, \&c., near the village.

In Cephalonia, ${ }^{3}$ holdings consist of from five to twenty-five acres, seldom in a continuous piece, but ' cut up into patches and intersected by other properties.'

In Corfu, ${ }^{4}$ the holdings are similar-infinitesimally small and intermixed pieces of land, especially in the olive groves, where however there are no divisions on the land and the 'oldest inhabitant' has to be asked for evidence of ownership in disputed cases.

${ }^{1}$ Consular Reports, pp. 23 and
$\begin{aligned} & 30 . \\ & 2 \text { Ibid. p. } 26 .\end{aligned}$


Crap. IV. Throughout the Greek nation, the peasants live in their houses in villages and not on separate estates. They help one another to avoid the expense of hired labour, and themselves work for hire on the estates of the large proprietors.

The open Professor Ridgeway has drawn attention to the field system in knowledge of this open field system in the Iliad and Homer. Odyssey $;^{1}$ and indeed the division of the land tilled by occupants of villages into small pieces or strips, in such a way that the holding of each consists of a number of isolated pieces lying promiscuously amongst the strips of others, over the whole area under plough, is a world-wide custom and is the habit alike of the east as of the west.

Though the assertion cannot yet be made that the $\kappa \lambda \hat{\eta}$ pos was thus arranged on the soil, it can do no harm at any rate to bear in mind this ancient and still used method of dividing land, whilst considering the question of the relation of the ownership of the soil to the rank and status of the tribesman.

\section{§ 2. THE RELATION OF THE KAHPO TO THE OIKO .}

Owner- THE connection of the possession of land with the ship of the headship of the family finds its counterpart in the
$\kappa \lambda$ pos vested in right of maintenance of those who had the true blood

the oikos. of that family. And in those countries where the sons remained until their father's death under his patria potestas they had to look to him for main

1 'The Homeric Land System,' Journal of Hellenic Studies, 1885. tenance derived from the $\kappa \lambda \hat{\eta}$ pos which descended to CHap. IV. him as the means of sustenance for himself and his family. Where the head of the family alone was responsible for the rites to the dead at the family altars, the position of a son would always be incomplete if he tried to establish during his father's lifetime a hearth and household of his own. And it has been already mentioned that it was necessary to emancipate a son from the family of his own father, before he could take property, passing on the death of his mother's relations to her issue, and assume his rightful position as their representative and the living: head of their household. ${ }^{1}$

According to Harpocration, the initiation into the mysteries of the hearth only took place on the actual assumption of the inheritance. ${ }^{2}$

Occasionally a father feeling the weight of years Depenwould be glad to pass on to his son during his life- ${ }_{\text {other }}^{\text {dence }}$ time some of his burden of responsibility by making of the

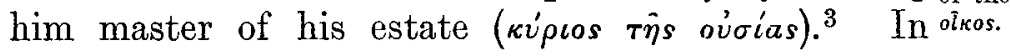
this case, the son would be responsible for the maintenance of his parent, a duty much insisted on by Plato and Isaeus. In fact the conclusion is justified that the family, until final subdivision into separate oiko, drew its supplies from the common inheritance, and that the subdivision of the means of subsistence was contemporaneous and co-extensive with the differentiation of the various branches of the original oikos along the lines of the rising generations.

\begin{tabular}{|c|c|c|}
\hline 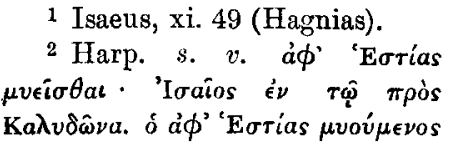 & 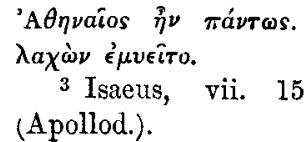 & $\begin{array}{l}\kappa \lambda \dot{\eta} \rho \varphi \delta \dot{\epsilon} \\
\text { and } 2 \% \text {, }\end{array}$ \\
\hline
\end{tabular}


Crap. IV. The same may be inferred from the words of Demosthenes describing the division of the property of Bouselos amongst his sons and the foundation of their several oikou.

'And all these sons of Bouselos became men, and their father divided his substance amongst them all, with perfect justice. And they having shared the substance, each of them married a wife according to your laws, and there were born children to them all, and children's children, and there grew up five oiko from the one oikos of Bouselos, and each dwelt apart, having his own house and his own offspring.'

In the meanwhile, before division, all sons had equal right to participate in the family goods after the father's death, and dowries had to be paid therefrom to the daughters. The eldest brother was guardian (кúpios) of his sisters and those of his brothers who were minors, inasmuch as he succeeded to his father's position of head of his kindred at the altars of their ancestors. But in Greece at any rate his authority over his brothers when once a division had taken place seems to have been slight if it existed at all.

The pre- Amongst the Gods, the three brothers Zeus, rogative of Poseidon, and Hades, sons of Rhea, shared their brother, inheritance from their father Kronos. They divided everything in three, shaking lots thereover ( $\pi a \lambda \lambda o_{-}$

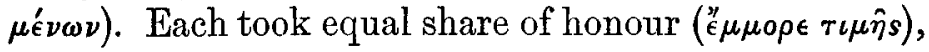
but earth and Olympos were common ( $\left.\xi \nu \nu \eta^{\prime}\right)$ to all. ${ }^{2}$ But Zeus was the first-born and 'knew more things'-

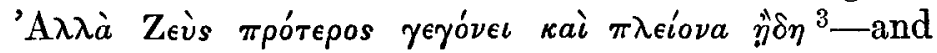
Poseidon therefore avoided open strife with him, how-

1055 et seq. Cf. 1149 where and 1086 where two brothers live one brother lives with his father apart but with undivided estate. after the division, whilst his $\quad 2 \mathrm{Il}$. xv. $187 \mathrm{sq}$. brother has a house of his own : $\quad{ }^{3} \mathrm{Ib}$. xiii. 355. ever unwillingly. Though Zeus be the stronger, Crap. IV. grumbles the Sea-god, let him keep to his third share and not interfere with his brothers' pleasure on their common ground, the earth. Let him threaten his sons and daughters who needs must listen to him (áкои́ovтac

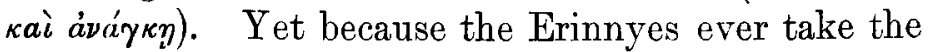

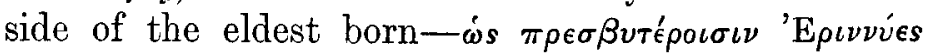

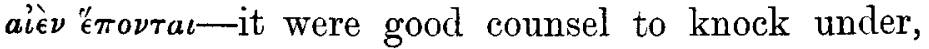
even though the division was made in perfect equality

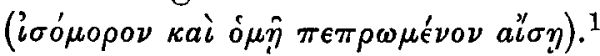

This passage contrasts the recognised autocracy of contrasted the head of the family over his own household with wower of the courteous deference of the younger brothers the head towards the eldest; and it is evidence, so far as it household. goes, that the eldest brother did not succeed to his father's power over his grown-up brothers, but owed what influence he did not obtain from the superior advantages of his age and experience, to a superstitious feeling that something was due to him in his position of head of the eldest branch of the family.

In the Odyssey, ${ }^{2}$ Zeus gives Poseidon the title of

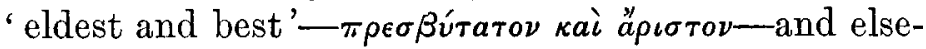
where Hera lays claim to the same birthright. ${ }^{3}$

The power of the head of a household must have been something much more real. Telemachos declares that he is willing that some other basileus in Ithaka

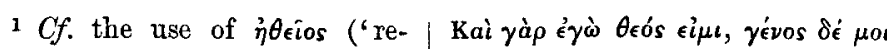
vered') as the stock epithet of ${ }_{\epsilon} \nu \theta \epsilon \nu, \delta \theta \epsilon \nu \sigma 0 \sigma^{\circ}$

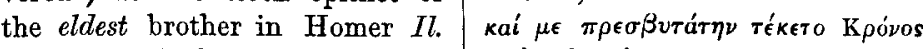
vi. 518, and elsewhere. Pollux, a

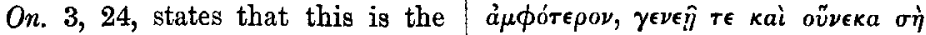
right use of the word.

2 Od. xiii. 142.

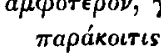

$3 \mathrm{Il}$. iv. $59 \mathrm{sq}$

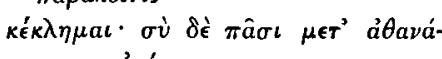

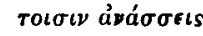


Crap. IV. should take the kingship, but he will be master over

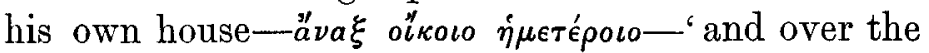
slaves that the divine Odysseus won for me.' ${ }^{1}$

In the Homeric Hymn to Hestia, that deity receives the title of honour of firstborn : the poet, by a fanciful blending of ideas, implying that the honour paid to the sacred hearth by the eldest of the family, fell to her share as the eldest born of the children of Kronos. $^{2}$

Aristotle says that every household is ruled ( $\left.\beta a \sigma \imath \lambda \epsilon \dot{v}_{\epsilon}^{\prime} \tau a \iota\right)$ by its oldest member ${ }^{3}$, and gives this prerogative of the household-basileus as the type and origin of the kingship in the village and the State. Reference has already been made, in the section on

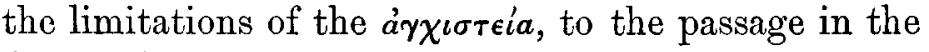
Gortyn law, viz.-

'The father shall have power over the children and the property to divide it amongst them .... As long as they (the parents) are alive there is no necessity for division' . . .4

No joint But it must be borne in mind that though the holding $\kappa \lambda$ inpos was set apart in theory for the use and father and sustenance of a head of a family with all his descenhis sons. dants, and was supposed to be inalienable therefrom, there is no reason to suppose that there existed among

\begin{tabular}{|c|c|}
\hline $\begin{array}{l}1 \text { Od. i. } 397, \text { cf. ix. } 115 . \\
2 \text { xxix. Eis'Eqríay. }\end{array}$ & 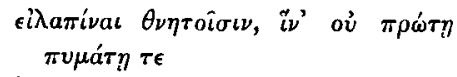 \\
\hline 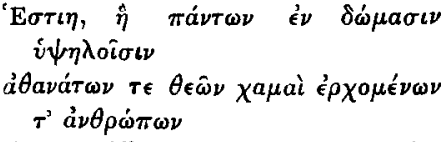 & 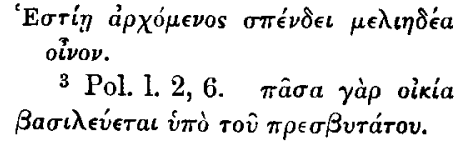 \\
\hline 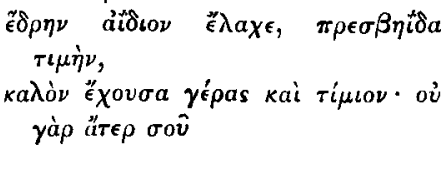 & $\begin{array}{l}\text { Cf. use of } \pi \rho \epsilon \sigma \beta \epsilon u \in \sigma \theta a c \text { in } \\
\text { Aesch. Ag. 1300, Choeph. } 486 \\
\text { and 631. } \\
4 \text { Gortyn Law, iv. 24, supra p. }\end{array}$ \\
\hline
\end{tabular}

the Greeks a system of joint holding between father CHAP. IV. and son. The ownership and management of the property vested in the head of the family. It is true that brothers did not always divide their inheritance on the death of their father, but their undivided right to their respective equal shares remained to each one and his descendants as an individual property, and they always seem to have had the expectation of an ultimate subdivision amongst the separate oirou that had sprung into being. ${ }^{1}$

The Gortyn Laws throw some light on the subject. Confirm-

As long as the father is alive, no man shall buy or atoryce of receive in pledge from the son any of the father's the Gortyn property. But what the son himself has earned, or inherited, he may sell if he like.

So too the father may not dispose of the goods of the children which they have earned or inherited.

Yet may a son's prospective share in his paternal inheritance be sold to pay any legal fine he has incurred. ${ }^{2}$

There is no joint holding here between father and son. The father is in undisputed possession, and nothing the son can do by private contract can affect his father's occupation. But if the son had a right of maintenance from his father during the lifetime of both, his expectation of succession to an equal share with his brothers would give him, so to speak, a value

1 In the island of Tenos, ac- Sales are recorded of a fourth part cording to an inscription of the of a tower and cistern; half a second or third century B.c., the house, lands, tower, \&c. Inscr. transfer of undivided fractions of Jurid. Gr.: Dareste, \&c. p. 63. houses and property was of ex- 2 Gortyn Laws, iv. 29-31. 
Crap. IV. in the public eye. In the event of his incurring a blood-fine, his father would presumably be obliged to pay it out of the patrimony; and when exaction of such penalties passed into the hands of a court, exception would hardly be made for long on behalf of the fine for murder over penalties for other crimes coming before the court. Although therefore for all ordinary purposes a son had no claim on the paternal estate beyond his maintenance, his right of succession might easily grow up in the eye of the law as an available asset capable of forfeiture with the theoretical assumption that the scapegrace was unfit to hold his position in the family. ${ }^{1}$ His future portion, thus becomingdeprived of a representative, might be wholly or in part confiscated to the State. There are many inscriptions confiscating to the State the goods of But the criminals who transgressed the laws therein; but Plato in theory evidently contemplated the possibility of wiping out inalienable the individual without depriving his descendants of from the
family. their inheritance. ${ }^{2}$ In such a case as wife-murder, he says, the husband's right of maintenance is extinguished from amongst his family, he should be banished and his name wiped out for ever, whilst his sons or relations enter upon the inheritance of his property immediately. No distinction is made by Plato, or in the Gortyn Laws in such a case between chattels and land. But inasmuch as all fines would be levied

1 Cf. Ordinunces of Manu, ix. $\mid$ and shareless, and be put under 213-4. 'If an eldest (brother), through avarice, commit an in'None of the brothers who jury against his younger (brothers), perform wrong acts deserve (share he should be made a not-eldest in) the property, ...' in the first instance upon the property of the guilty Crap. IV. individual, it may be assumed that his own earnings went first, and that only in extreme cases would the ancestral land of the family be sold. Even then, in Israelite law, it was expected that the land would be redeemed by the nearest relative, ${ }^{1}$ so that the result would be that the land would go out of the family only when no relative could be found rich enough to pay the fine out of his chattels.

It is interesting to find analogous provisions in close the customs of Gavelkind of ancient Kent. Under analogy in the system of Gavelkind equal division of property of Gavelamongst sons obstinately held its own against the Kent. incursions of the right of primogeniture; and the connection of the family with their land seems to have been regarded as especially privileged in spite of the growth of Feudalism.

\footnotetext{
'If any tenant in Gauelkinde be attainted of felonie, for which he suffereth execution of death, the king shall have all his goods, and his heire forthwith after his death shall be inheritable to all his landes and tenements which he held in Gauelkinde in fee, and in inheritance : and he shall hold them by the same services and customes as his auncestors held them: whereupon it is said in Kentish :

"The father to the boughe, And the sonne to the ploughe.' 2
}

It had become customary to allot to a bastard son Allotment who was prevented by his birth from ranking with or 'gastar' to his brothers, and who had no place in the kindred, son. some smaller substance as a means of subsistence.

\begin{tabular}{l|l}
\hline 1 Lev. xxv. 25; Jerem. xxxii. & \multicolumn{1}{|c}{ 'The fader to the bonde } \\
And the son to the londe.' \\
8.
\end{tabular}


Chap. IV. Odysseus pretends he was in this position, and relates how his proud brothers allotted him but a

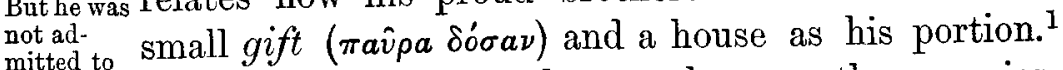
mitted to 's Isaeus mentions that, only on the acquiesfamily. cence of the true son, was admission granted to a bastard into the phratria. Even then he was not apparently taken into his father's family, but allotted a farm $\left(\chi \omega\right.$ piov $^{\prime}(\nu)$ by his brother and, as it were, launched into the world to start a family of his own, without any further claim upon the property of his father. $^{2}$

His introduction and admission to a phratria and deme, as a descendant of an old family, so far removed the stigma of his birth as to give him the title of citizen, and thus afforded him the qualification for holding land. Yet the knowledge of his real parentage bereft him of the right of sharing equally with the rest of his father's sons, and compelled him to be satisfied with the bare means of subsistence wherewith to found and continue a house of his own. ${ }^{3}$

When citizenship was conferred upon a beneficent stranger, it was the custom at the same time to assign him and his descendants a house and some land. We hear of grants on such occasions consisting of a $\kappa \lambda \hat{\eta}$ pos in the plain, a house, and a garden free of taxes; a half-к $\lambda \hat{n}$ os in the plain, a house and a garden of half the area of the preceding grant, \&c. In the fourth century B.c. a similar grant takes the form

\footnotetext{
1 Od. xiv. 209. Cf. Pindar, 3 Cf. Eur. Ion 1541.

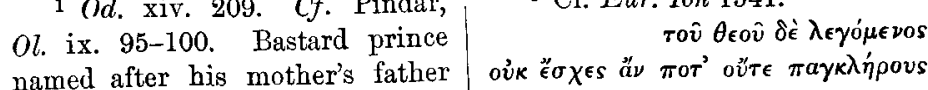

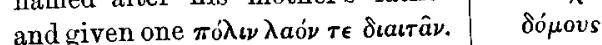

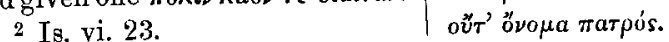

of so many plethra as a patrimony or ever. Some- Chap. IV. times, as at Sparta in the second century B.c., the estate was allotted to the newly-made citizen only on condition of residence within the borders of the State. ${ }^{1}$

\section{§ 3. THE HOUSEHOLDER IN INDIA : THE GUEST.}

Sir Henry S. Maine in his Early Law and Cus- Depend. tom $^{2}$ quotes Narada in illustration of the composition ence of of the early Indian family. A son 'is of age and ing their independent in case his parents be dead: during lafe. their lifetime he is dependent, even though he be grown old.'

Further information on this subject is afforded by the Ordinances of Manu, where the position of the first-born with regard to his younger brothers is given at some length. ${ }^{3}$

\footnotetext{
'After both the father and the mother (are dead), the brothers, His pro having come together, should divide the paternal inheritance : for perty while the two (parents) are alive the (sons) have no power (over the amongst property)

'Now the eldest (or best) alone may take the paternal property his death.

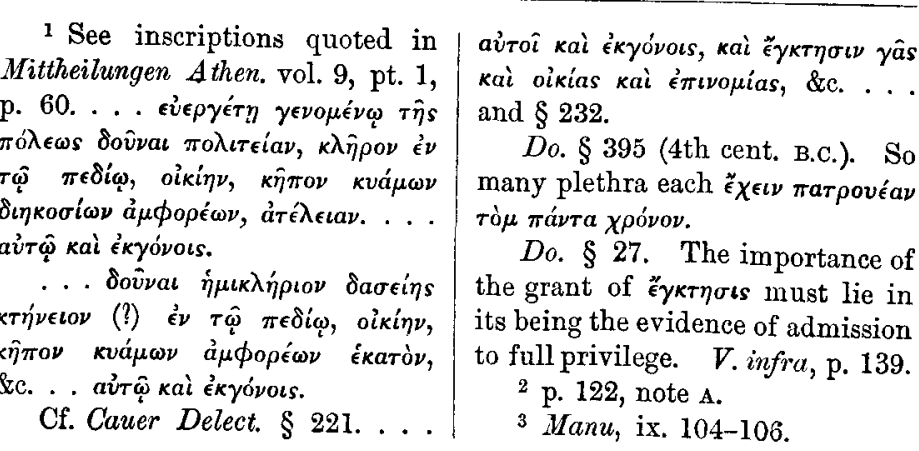


Crap. IV. without leaving anything, and the remaining (brothers) may live supported by him just as (if he were their) father. ${ }^{1}$

But special respect

the eldest

the elde

c B means of the eldest (son) as soon as he is born a man becomes possessed of a son, and is thus cleared of his debts towards the manes; therefore this (eldest son) deserves the whole (inheritance).'

Likewise: "If among brothers born of one father, one should have a son, Manu said all those brothers would be possessed of sons by means of that son.' ${ }^{2}$ But this seems to apply only to the son born to the eldest, for if a younger brother married before the eldest and performed the daily sacrifices, he sent himself, his brother, and his wife 'to Hell.' 3

The eldest, if he performs his duty, 'causes the family to flourish' and 'is most honoured among men.' He alone is 'duty-born,' through him his father 'pays his debt'; other sons are only 'born of desire.' As long as his conduct is befitting, he must be honoured 'like a father, like a mother,' but if not, he only receives the respect of an ordinary relative. ${ }^{4}$

The brothers may live together in this way, ${ }^{5}$ but if they divide and live apart, the separate ceremonies necessitated by their separate households will multiply the performance of religious duties, to the advantage of all.

The duties The title of Householder, moreover, was more than a name.

\footnotetext{
'As all beings depend on air, so all orders depend on the householder.'

'Because men of the three (other) orders are daily supported by the householder alone with knowledge and with food, therefore
}

\begin{tabular}{l|l}
\hline iv. 184. 'An elder brother & 3 iii. $171-2$. \\
is equal to a father.' & 4 ix. 110 and 213. \\
g ix. 182. & 5 ix. 111.
\end{tabular}

the householder (is) the chief order. That order must be upheld Chap. IV. strenuously by one desiring an imperishable heaven, and who here desires perpetual happiness. ....

'The seers, manes, gods, beings, and guests also make entreaty to those heads of families for support. (This duty must, therefore,) be done by a man of discernment.'

'As all rivers, ... go to (their) resting-place in the ocean, so men of all orders depend on the householder.'2

Let a householder perform the household rites according to rule with the marriage fire and the accomplishment of the five sacrifices and the daily cooking. The sacrifices are :-

Teaching the Veda is the Veda sacrifice :

Offering cakes and water is the sacrifice to the manes:

An offering to fire (is the sacrifice) to the gods :

Offering of food (is the sacrifice) to all beings:

Honour to guests is the sacrifice to men.

'Whoever presents not food to those five, the gods, guests, dependents, the manes, and himself, though he breathe, lives not.' 3

The guest takes a very high place, and his presence Honour is a revered addition to the family sacrifices; so much gaid to the so that it was thought necessary to state definitely that ' if the guest appears after the offering to all the gods is finished, one should give him food as best one can, but should not make (another) offering.' 4

The same virtue seems to have been considered by the Greeks also to lie in the presence of the guest. In Euripides' Elektra, Aigisthos, hearing from Orestes that he and his friend are strangers, promptly invites

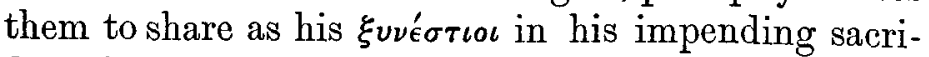
fice of a bull to the nymphs, promising to send them on their way in the morning. ${ }^{5}$

\begin{tabular}{l|l}
\hline & iii. 77 et seq. \\
2 & $\begin{array}{l}4 \text { iii. } 108 . \\
\text { vi. } 90 .\end{array}$ \\
3 iii. 67,70, and 72. &
\end{tabular}


Chap. IV. Earlier in the play during the plotting of Aigisthos' death, it is taken for granted that directly he sees them he will call them thus to join him at the sacrifice and the feast. ${ }^{1}$

Alkinoos expresses the feeling of the Homeric age when he says:

'In a brother's place stand the stranger and the suppliant, to him whose wits have even a little range. ${ }^{2}$

Nestor at Pylos, making sacrifice to Poseidon with his sons and company, welcomes the unknown Telemachos and Mentor to the sacrificial feast. ${ }^{3}$ When the duty of feeding the guests has been satisfactorily accomplished, he then asks them whether they are merchants or pirates, that 'wander over the brine at hazard of their own lives bringing bale to alien men!'

It would appear that the virtue lay in the hospitality of the host and not in the worthiness of the guest, and that therefore it was worth while to run the risk of having invited the presence of a polluted man whose impiety in not refusing to partake would doubtless fall on his own head.

To return to the organisation of the Indian inRight of mainof the of the mounger

member
family.

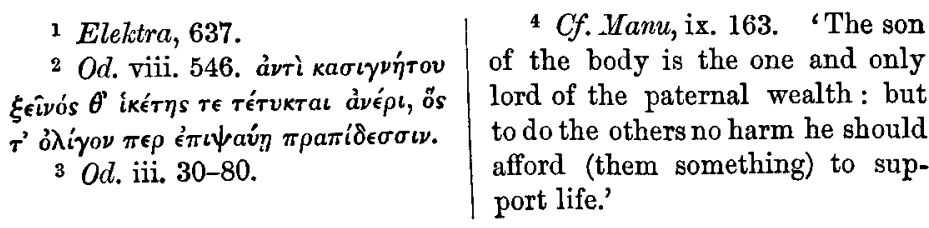

all 'perfect in their own occupations,' and they come CHAp. IV. to an equal division, 'some trifle should be given to the elder (brother) to indicate an increased respect for him.' 1 Also if in division there remains over an odd goat or sheep, or animal, it goes to the eldest brother.

If any brother has disgraced himself, he does not deserve a share in the property. ${ }^{2}$

Sisters' portions are allotted out of all the brothers' shares equally. ${ }^{3}$

Property is divided once only. ${ }^{4}$ But if 'on living together after being separated, they divide (the inheritance) a second time, in that case the division should be equal, (as) in that case no right of primogeniture occurs.' 5

The father's wealth acquired during his lifetime is at his own disposal, and need not be divided amongst his sons. ${ }^{6}$ Likewise with any property acquired by the sons. ${ }^{7}$ If 'any one of the brothers, being able (to support himself) by his own occupation, does not desire (his share of the) property,' he may be excluded from the division, but 'something for his support' should be given him to discharge his claim of maintenance from the family at any future time. ${ }^{8}$

\begin{tabular}{l|l}
1 Manu, ix. 115. & states the contrary. 'A wife, son, \\
2 ix. 214. & and slave are said to be without \\
3 ix. 118. & property : whatever property they \\
4 ix. 47. & acquire is his to whom they \\
5 ix. 210. & (belong).' \\
6 ix. 209. & 8 ix. 207. \\
7 ix. 208.
\end{tabular}




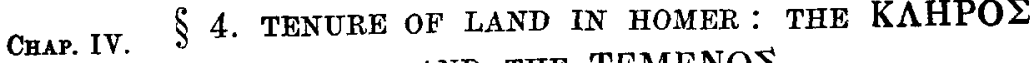 AND THE TEMENO乏.}

In the Homeric poems, written, as they are, from

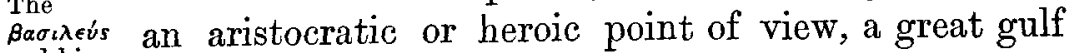
and his always exists between the royal or princely class and with the the ordinary tribesmen.

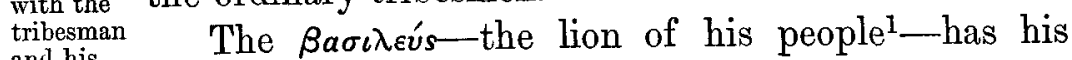

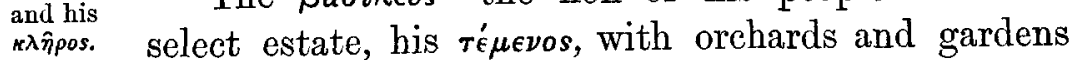
of considerable extent; while the swarms of tribesmen are allotted their $\kappa \lambda \hat{\eta} \rho \circ$ in the open field, their share in the common pasture, and depend on each other for help in the vintage and harvest.

The pos- The possession of large estates and of multitudinous sessions of flocks and herds was one of the privileges of the

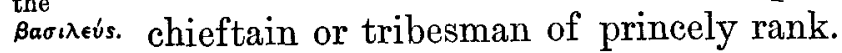

'For surely his livelihood (i.e. Odysseus') was great past telling, no lord in the dark mainland had so much, nor any in Ithaka itself ; nay, not twenty men together have wealth so great, and I will tell thee the sum thereof. Twelve herds of kine npon the mainland, as many flocks of sheep, as many droves of swine, as many ranging herds of goats, that his own shepherds and strangers pasture. And ranging herds of goats, eleven in all, graze here by the extremity of the island with trusty men to watch them.' 2

Bellerophon migrated from his own country and settled under the patronage of the king of Lykia. ${ }^{3}$ He married the king's daughter, and to complete his qualification and to confirm his princely status as a

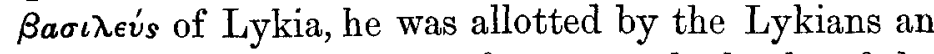
estate where the plain was fattest on the banks of the

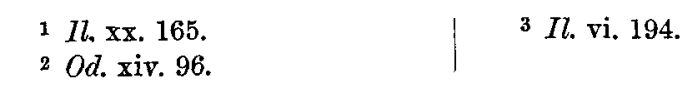

river, consisting half of arable, half of vineyard, the CнAт. IV. latter presumably on the slopes of the sides of the valley. ${ }^{1}$ Besides these no doubt he had flocks and herds on the mountains, with steadings and slaves for their protection. It is improbable that the fattest of the plain was unoccupied before, and it must therefore be supposed that the system of agriculture was such as to admit of such a partition and the consequent readjustment, or that the dispossessed tribesmen had to compensate themselves with land out of the common waste.

In somewhat similar wise Tydeus at Argos wedded one of the daughters of Adrastos, and dwelt in a house full of livelihood; and 'wheatbearing ápovpa enough were his, and many were his orchards of trees apart, and many sheep were his.'

In the description of the Shield of Achilles in the Iliad a vivid contrast is drawn between the rich

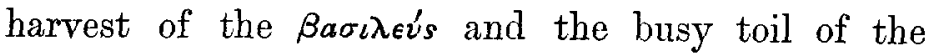
tribesmen.

'Furthermore he set therein a $\tau^{\prime} \mu \epsilon \nu$ os deep in $\operatorname{corn}^{3}$ where hinds $(\ddot{\epsilon} \rho \bullet \theta u)$ were reaping with sharp sickles in their hands ... and among them the $\beta a \sigma i \lambda \epsilon v_{s}$ in silence was standing at the swathe with his staff, rejoicing in his heart.'

Meanwhile henchmen are preparing apart a great feast for himself and his friends, and the women are strewing much white barley to be a supper for the hinds. ${ }^{4}$

\begin{tabular}{|c|c|}
\hline $\begin{array}{l}4 ; \text {; ff. xx. } 184 . \\
21 . \\
\text { nging to a basileus.' } \\
\text { xi. } 67 . \text { 'As when }\end{array}$ & $\begin{array}{l}\text { ploughland of a rich man of } \\
\text { wheat and barley, and thick fall } \\
\text { the handfuls'. . } \\
\text { This contrast is drawn by } \\
\text { Professor Ridgeway : op. cit. p. } 19 \\
\text { Journal of Elllenic Studios }\end{array}$ \\
\hline
\end{tabular}


Chap. IV. But in the great common field all was toil and The $\mathrm{\lambda} \hat{\text { ppos }}$ action; many ploughers therein drave their yokes to of the
tribesman probably common tribesman was not an estate ( $\tau^{\prime} \mu_{\mu \epsilon \nu o s)}$ cut inthe in out of the plain, but an allotment ( $\kappa \lambda \hat{\eta} \rho \circ s)$, probably the plain, of strips as in Palestine to-day, in the open fields that lay around the town. On the wheatbearing plain round Troy lay the stones that former men, before the ten years' war, had used to mark the balk or

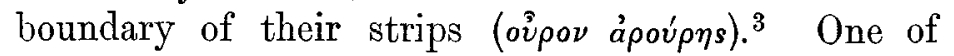
these Athena uses to hurl against Ares, who, falling where he stood, covers seven of the pelethro that the stones were used to divide. A pinnacle of stones is the only boundary to be seen to this day between the strips of cornland in Palestine. Easily dislodged as these landmarks were, they were specially protected by a curse against their removal, and were with the Greeks under the awful shadow of a special deity of boundaries. ${ }^{4}$ They seem however to have been liable to considerable violation. The ass, according to Homer, being driven along the field-way, if his skin was thick enough, easily disregarded the expostulations of his attendants, and made free with the growing crop. $^{5}$ Homer also describes a fight between two men with measuring rods in the common field, ${ }^{6}$ and Isaeus ${ }^{\top}$ relates how an Athenian citizen flogged his brother in

\begin{tabular}{|c|c|}
\hline 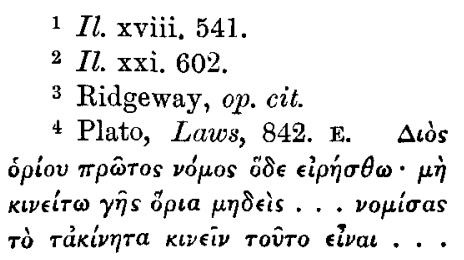 & 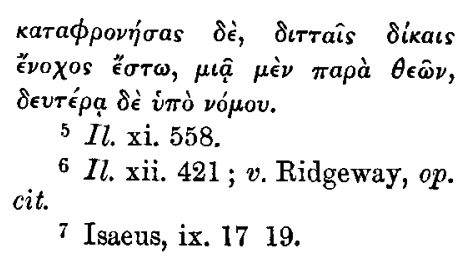 \\
\hline
\end{tabular}

a quarrel over their boundary so that he afterwards CHap. IV. died, whilst the neighbours, working on their land around, were witnesses of what took place.

Land was brought into cultivation, no doubt, as it was wanted. Achilles contemplates that some of the rich fields of his friends may be exceedingly remote, so that it would be a great thing to spare the ploughman a journey to the nearest blacksmith. And no doubt the powerful men of the community would, by means of their slaves or retainers, acquire additional wealth by reclaiming lands out of the way and therefore requiring a strong hand to protect them, which were profitable by reason of their very fatness. ${ }^{1}$ Such acquisitions would not be included in the rérevos of the prince, the very word $\tau \dot{t} \mu \epsilon \nu$ s implying an area of land cut out of the cultivated land of the community, generally described as being in the plain ( $\pi \dot{\epsilon} \delta \iota \nu \nu)$.

Such allotments of land seem only to have been The made to princes and gods, but when once allotted, ${ }^{\beta a \sigma}$ 'honoured remained as far as can be seen the property of their like a god descendants. It was a common fancy of the Homeric of a aíu prince that he was worshipped as a god, and they ${ }^{\text {evos. }}$ often mistook each other for some deity. The godlike Sarpedon asks his cousin Glaukos, wherefore are they two honoured in Lykia as gods, with flesh and full cups and a great ré $\mu \epsilon \nu o s^{2}$

As the possession of full tribal blood was necessary for the ownership of a $\kappa \lambda \hat{\eta} \rho o s$, so princely blood was the qualification for the enjoyment of a $\tau \tau^{\prime} \mu \in \nu o s$.

1 tioyes ảypoi. Il. xxiii. 832. v. Ridgeway, op. cit. p. 16.

2 Il. xii. 313 . Cf. $I l$. ix. 297.
A good king also has power over the crops, etc., to bring plenty. See Od. xix. 110-5. Frazer, Golden Bough, i. 8 et seq. 
Chap. IV. The honoured individual need not be a king or overlord, but besides his valour he must have in his veins the all-potent blood royal, without which his privilege was no greater than that of other rich tribesmen.

It was not till the king of Lykia had satisfied himself that Bellerophon was 'the brave offspring of a god,' that he gave him honour, and the Lykians

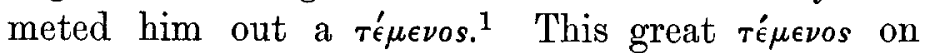
the banks of the Xanthos, half arable and half vineyard, remained in the possession of his grandchildren, Sarpedon and Glaukos, apparently still undivided, though they were not brothers but first cousins. $^{2}$

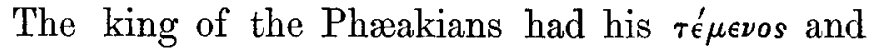
fruitful orchard near but apart from the fields and tilled lands of his townsfolk. ${ }^{3}$ Odysseus it seems had more than one $\tau$ '́ $\mu \epsilon \nu o s .{ }^{4}$

Once in the Iliad the epithet marpoiios is ap-

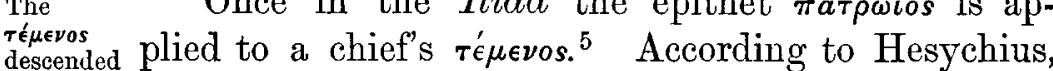
from matpwíios means 'handed down to one's father from father to
son. this sense.

The kingship itself in Ithaka was considered as part of Telemachos' patrimony: 'Never may Kronion

\begin{tabular}{|c|c|}
\hline 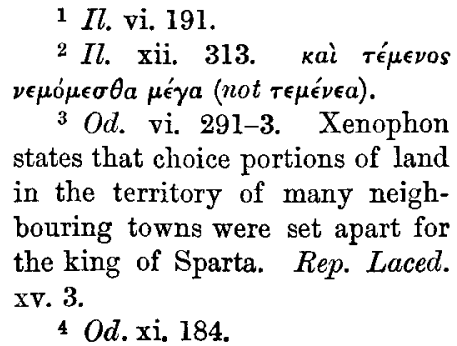 & 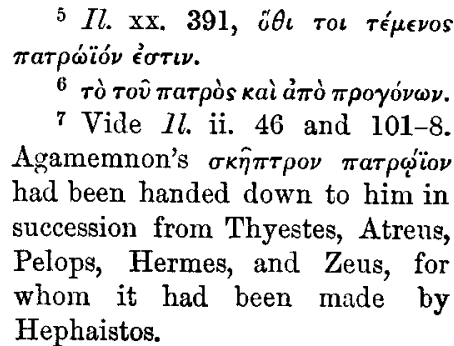 \\
\hline
\end{tabular}

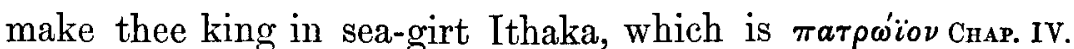
to thee by birth $(\gamma \in \nu \in \hat{\eta}) .{ }^{\prime} 1$

But though the $\tau \dot{\epsilon} \mu \epsilon \nu o s$ and the kingship were both equally marpwiia, they did not together constitute an indivisible inheritance. Any one of the blood could enjoy possession of the land, whilst the over-lordship must necessarily descend in the eldest or the most able line.

In his answer to the malignant wish quoted above, Telemachos does not speak as if he contemplated giving up any tangible property. The bestowal of the kingship, though due to him by inheritance

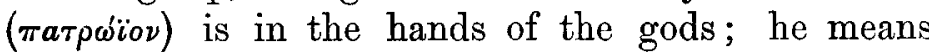
to be master (a $\left.{ }^{\prime} \nu a \xi\right)$ of whatsoever Odysseus his father won for him.

It is interesting to compare this choice of Iason's Telemachos with the exactly opposite choice made by his greatIason, as told by Pindar, when he came back to claim grand; his inheritance which had been seized in the mean- estate. time by his second cousin, Pelias.

He has come home, he tells Pelias, to seek his father's ancient honour which Zeus had of old bestowed on his great-grandfather Aiolos and his sons. It is not for them now, being of the same stock (óónovor), to divide the great honour of their forefathers with sword and javelin. He will give up all the sheep and herds of kine, and all the fields of late robbed from his sires, though they make fat

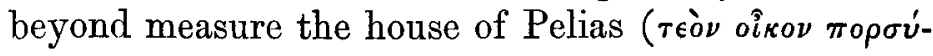

\footnotetext{
1 Od. i. 386. Cf. Od. ii. 22. Cf. Od. xi. 185. Telemachos

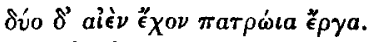

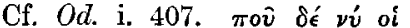

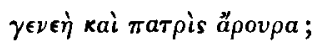


Chap. IV. vovt' a' ${ }^{\prime} a \nu$ ). But the kingly sceptre and throne of his father must be his without wrath between them. And Zeus, the ancestral god of them both (Zeìs o $\gamma^{\epsilon} \nu_{\epsilon}^{\prime} \theta \lambda$ ios a $\mu \phi o \tau$ '́fors), is witness to their oath. ${ }^{1}$

Rich tribesma might several

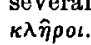

Property in land could also be accumulated in the hands of individuals not necessarily of princely station. Odysseus tells a tale of how he took a wife of 'men with many $\kappa \lambda \hat{\eta} \rho \circ \iota^{\prime}$ ( $\pi \circ \lambda \nu \kappa \lambda \eta_{\rho} \rho \omega \nu$ à $\nu \theta \rho \omega \pi \omega \nu$ ) by reason of his valour. ${ }^{2}$ The $\kappa \lambda \hat{\eta}$ pos must therefore at that time have been at any rate roughly of some recognised area. Perhaps the tendency, so fatal to Sparta, for the possession of the original shares or allotments of many families to accumulate in the hands of the powerful or rich, had already set in. In later colonisations and assignments of new land the $\kappa \lambda \hat{n}$ po were often equally divided, ${ }^{3}$ and the gift of citizenship, as has been already mentioned, was sometimes accompanied by a grant of a half-kleros ( $\left.\dot{\eta} \mu \iota \lambda \eta^{\prime} \rho \iota \nu \nu\right)$. Did the $\kappa \lambda \hat{\eta} \rho \circ$ s then represent in theory an area of cultivated ground capable of sustaining a single household?

\section{\$5. EARLY EVIDENCE continued: THE K $\Lambda$ HPO AND THE MAINTENANCE OF THE OIKO}

The $\kappa \lambda \hat{p}$ os THERE are signs in Homer of the existence, was the
holding of already insisted upon for later times, of the connec-

the head tion of the ownership of property with the headship of a household. It follows that if the head of a

\footnotetext{
1 Pindar, Pyth. iv. 255 et seq.
2 Od. xiv. 211.
}

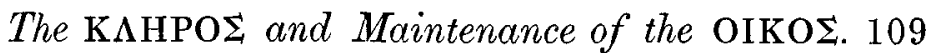

family was the only owner of land, the desire of Crap. IV. establishing a family and thereby preserving at the of an same time the acquired property and the name of the oinos, possessor, made the acquisition of a wife a real necessity for the owner of land.

Eumaios, the swineherd, says that Odysseus would have given him a property ( $\kappa$ i $\hat{\eta} \sigma \iota s)$, both an oîkos and a $\kappa \lambda \hat{r}$ pos and a shapely wife. ${ }^{1}$ And Odysseus in one of his many autobiographies speaks of taking a wife as if it were the necessary sequel to coming into his inheritance. $^{2}$

Even Hesiod, the son of a poor settler, without much property to keep together, if we can take Aristotle's reading of the line, gives the necessary outfit for a peasant farmer in occupation of a small $\kappa \lambda \hat{\eta} \rho o s$, as a house, a wife, and a plough-ox. ${ }^{3}$

Aristotle quotes this line of Hesiod, in his argument that the oikos was the association formed to supply the wants of each day, ${ }^{4}$ its members being called by Charondas, he says, ó $\mu \circ i^{\prime} \pi v o \iota$ (sharers in the mealbin), and by Epimenides the Cretan óо́като (sharers of the same plot of ground). ${ }^{5}$ And he might have added that Pindar uses the word $\delta \mu{ }^{\prime} \kappa \lambda a \rho o \iota$ to mean 'twins.' ${ }^{6}$

\begin{tabular}{|c|c|}
\hline 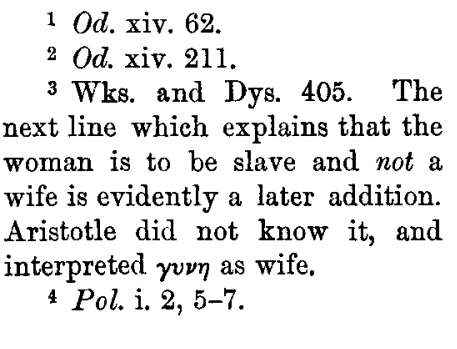 & $\begin{array}{l}{ }^{5} \text { I am indebted to Professor } \\
\text { Ridgeway for the right meaning } \\
\text { and derivation of this word, which } \\
\text { stands for o } \mu \text { ók } \eta \pi \circ \text {, having the a } \\
\text { long and not short as stated in } \\
\text { Liddell and Scott's Dictionary. } \\
\text { Another reading is ó } \mu \text { ókanvo which } \\
\text { would mean sharers of the smoke } \\
\text { or hearth. } \\
{ }^{6} \text { Pindar, Nem. ix. } 11 \text {. }\end{array}$ \\
\hline
\end{tabular}


Chap. IV. A household, according to Aristotle, consisted and sup- thus partly of human beings, partly of property. ${ }^{1}$

plied the So closely is the idea of livelihood bound up with tenance of that of the house or oi $\kappa o s$, that Telemachos can say the house. without incongruity that his house is being eaten by the wooers:-

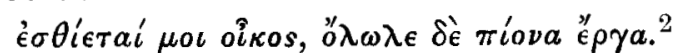

The sanctity shared by the hearth and its sustenance may be illustrated by Odysseus' oath, which occurs three times in the Odyssey: "Now be Zeus my witness before any god, and the hospitable board and the hearth of blameless Odysseus whereunto I am come.' $^{3}$

Force of When once the hospitable board had laid its the bond mysterious spell on the relations of host and guest,
of food. the bond was not easily dissolved. Glaukos and Diomedes meet ' in the mid-space of the foes eager to do battle,' fighting on opposite sides. Nevertheless because the grandfather of one had entertained the grandfather of the other for twenty days and they had parted with gifts of friendship, their grandsons refrain from battle with each other, pledge their faith, and exchange armour as a witness to others that they are guest-friends by inheritance ("o $\phi \rho a$ кai oi $\delta \epsilon ~ \gamma \nu \hat{\omega} \sigma \iota \nu$,

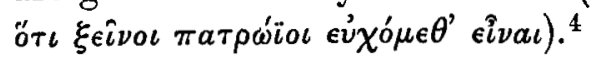

If such force lay in the entertainment of a guest for a few days, some idea can be formed of the virtue underlying the meaning of such words as ónooi $\pi v o \iota$

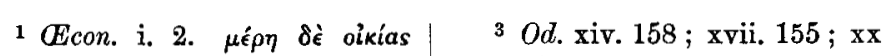

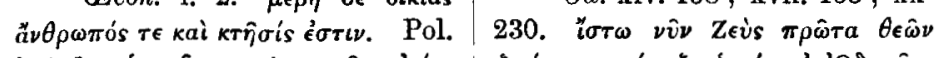

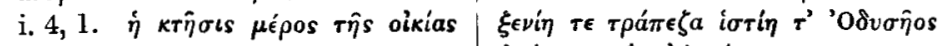

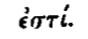

2 Od. iv. 318.
}

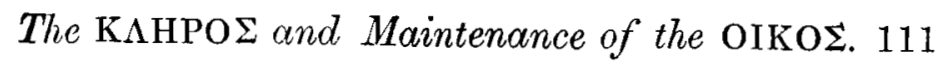

and $\dot{\rho} o_{\kappa} a \pi \circ$, and binding together those habitually Crar IV. nourished at the same board.

If sons married during their father's lifetime The need without any particular means of livelihood, they tablished could live under his roof and authority, forming a housebold great patriarchal household like that of Priam and feit. his married sons and daughters at Troy. But when a household dispersed before the marriage of the sons and the inheritance was divided amongst them, it was deemed indispensable for them to take wives, and each provide for the establishment of his house and succession. This necessity is the underlying motive of the compulsion over the only daughter left as é $\boldsymbol{i}^{\prime} \kappa \lambda \eta \rho \rho s$ to marry before a certain age, exercised by the Archon at Athens. There the idea of the need of a continuous family (as well as for other purposes), to keep together the property, had grown up apparently as a reflection, so to speak, of the obvious importance of the property to the family for the maintenance of itself and its ancestral rites.

Though evidence is wanting for the raison d'etre of this sentiment in Homer, the existence of the feeling can hardly be denied.

The $\kappa \lambda \hat{\eta}$ pos, at any rate, continued to pass from father to son in the family of the tribesman or citizen. Hector encourages his soldiers by reminding them that though they themselves fall in the fight, their children, their house (oikos), and their $\kappa \lambda \hat{n}$ pos will be unharmed, provided only that the enemy are driven back. $^{1}$

The sentiment that a man was not really' estab- 
Crap. IV. lished, according to the estimation of the Homeric Greeks, until the continuity of his house was provided for, seems to explain the two references to Telemachos in the Iliad. Odysseus is twice mentioned, as Mr. Leaf points out in his Companion to the Iliad, ${ }^{1}$ as the father of Telemachos, simply because it was considered a title of honour to be named as sire of an established house. No other mention of Telemachos occurs in the Iliad.

Failure of heirs was, as in later times, the great disintegrating factor and danger to the continuity of the family holdings. As long as a direct descendant was to be found, the property was safe.

Eurykleia comforts Penelope in her fear for the absent Telemachos, saying:-

' For the seed of the son of Arkeisios is not, methinks, utterly hated by the blessed gods, but someone will haply yet remain to possess these lofty halls and the fat fields far away.' 2

Is it by accident that she here chooses the name of Arkeisios to describe the head of the family of Laertes and Odysseus? He was Laertes' father, and in Telemachos, if he was preserved alive, he would thus have a great-grandson to represent his line in the succession to his property.

The diversion of inheritance to any property from

\begin{tabular}{|c|c|}
\hline $\begin{array}{l}1 \text { p. } 75 . \text { Mr. Leaf mentions } \\
\text { other countries where the father } \\
\text { takes a new name as father of his } \\
\text { eldest son. } \\
{ }^{2} \text { Od. iv. } 754-7 .\end{array}$ & 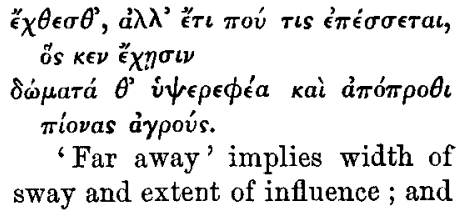 \\
\hline 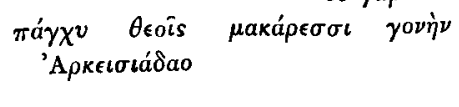 & $\begin{array}{l}\text { the protection of ontlying proper- } \\
\text { ties wonld necessitate a great } \\
\text { name and a strong hand. }\end{array}$ \\
\hline
\end{tabular}

the direct line is spoken of in Homer as a lamentable CHAp. IV. circumstance greatly intensifying the natural grief at $\overline{\text { Diversion }}$ the death of the direct heir.

of inheri-

'Then went he after Xanthos and Thoon, sons of Phainops, death of

striplings both ; but their father was outworn of grievous age, and heir a sore begat no other son for his possessions after him. Then Diomedes

slew them and bereft the twain of their dear life, and for their father left only lamentation and sore distress, seeing he welcomed them not alive returned from battle: and kinsmen divided his substance $(\kappa \top \hat{\eta} \sigma \iota s) .{ }^{\prime} 1$

In the tumultuous times of the Odyssey the right of succession must often have been interrupted by war and violence. Possessions, not only of land, had to be defended by the sword even during the lifetime of the acquirer. This prompts one of the wishes of Odysseus in his prayer at the knees of Arete:-

'And may each one leave to his children after him his possessions in his halls and whatever dues of honour the people have rendered unto him.' 2

The same anxiety prompts his question to his mother in Hades, to which he obtains answer :-

'The fair honour ( $\gamma$ ćpas) that is thine no man hath yet taken,

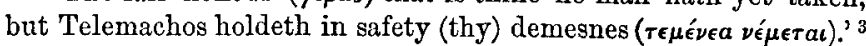

The belief in the inseparability of the ancestral Naboth's holding and the family was strong in Samaria at the vineyard time of Ahab. The King offered Naboth another his family vineyard better than his own in exchange for the one at Jezreel near the palace, or, should he prefer it, its worth in money. But Naboth said to Ahab, 'The Lord forbid it me, that I should give the inheritance of my fathers unto thee.' 4

Both the Hebrew narrators and the Greek trans-

\begin{tabular}{|c|c|}
\hline $\begin{array}{l}1 \text { Il. v. } 151 \text { et seq. } \\
\text { Od. vii. } 150 .\end{array}$ & 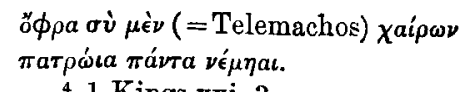 \\
\hline
\end{tabular}


Crap. IV lators describe Ahab finally as taking the vineyard at Naboth's death by inheritance (LXX. $\kappa \lambda \eta p o \nu o \mu \epsilon \hat{\nu})$, in spite of the violence of the means of acquiring it adopted by Jezebel.

The limited right of the prince to alienate from his family any part of his possessions is thus alluded to by Ezekiel :-

' Thus saith the Lord God; If the prince give a gift unto any of his sons, the inheritance thereof shall be his sons'; it shall be their possession by inheritance. But if he give a gift of his inheritance to one of his servants, then it shall be his to the year of liberty : after it shall return to the prince: but his inheritance shall be his sons' for them.'1

\section{§6. EARLY EVIDENCE continued: THE TEMENO乏, AND THE MAINTENANCE OF THE CHIEFTAIN.}

The main-

Ir must be borne in mind that the tribal idea of tenance of the chieftainship sanctioned the custom that the levied maintenance of the chieftain and his companions or upon the people retainers should be levied at will upon the property of the people. This privilege is very wide spread, and had its origin in the earliest times.

The levies were claimed under the name of gifts, and earned for the princes the title of $\delta \omega \rho$ oqúros. As Telemachos declares, "it is no bad thing to be a $\beta a \sigma i \lambda \epsilon v^{\prime}$, and quickly does his house become rich and he himself most honoured.' ${ }^{2}$

The royal family and nobles ${ }^{3}$ levied contributions on their own or conquered peoples apparently at will

\begin{tabular}{|c|c|}
\hline 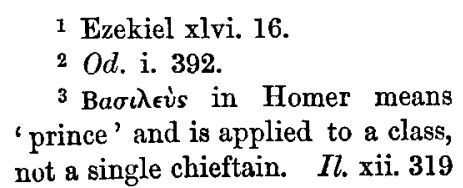 & $\begin{array}{l}\text { of Sarpedon and Glaukos. Il. iv. } \\
96 \text { of Paris. Od. i. } 394 \text { of the } \\
\text { Ithakans. Od. viii. } 41 \text { and } 390 \\
\text { of the Phaeakians. } C f . \text { Hesiod } \\
W . \& D .37-9 .\end{array}$ \\
\hline
\end{tabular}

in Homer. Agamemnon calls together the Greek Crap. IV. chiefs :-

'Ye leaders and connsellors of the Argives ... who drink

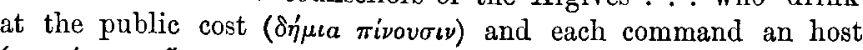

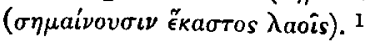

Priam chides his sons :-

'Ye plunderers of your own people's sheep and kids (å $\rho \nu \omega \hat{\omega} \nu$

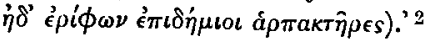

Telemachos declares that if the wooers eat up all his sheep and substance, he will go through the city (катà ă $\sigma \tau v)$ claiming chattels until all be restored. ${ }^{3}$

Alkinoos proposes to give gifts to Odysseus, and they themselves going amongst the people (áreıpó$\mu \in \nu o \iota$ ката̀ $\delta \hat{\eta} \mu o \nu$ ) will recompense themselves: "for hard it were for one man to give without return.' 4

'Then I led him to the house,' says Odysseus, 'and gave him good entertainment ... out of the plenty in my house, and for the rest of his company ... I gathered and gave barley meal and dark wine from the people $(\delta \eta \mu \dot{\theta} \theta \epsilon \nu)$ and oxen to sacrifice to his heart's desire.' 5

These passages throw light on Agamemnon's The right offer to Achilles of seven well-peopled towns, whose to receive inhabitants would enrich him with plenteous gifts. ${ }^{6} \underset{\text { be trans }}{\text { could }}$ The proposal of Menelaos to empty a city of Argos, ferred to to accommodate Odysseus and his people, seems to be of quite a different order, and betrays to us that the tyranny of the tribal chieftain, so conspicuous in other nations, was no less a reality also amongst the Greeks under Achaian rule. ${ }^{7}$

In the Indian society that was regulated in In India

$$
\begin{array}{ll}
1 & \text { Il. xvii. } 250 . \\
2 & \text { Il. xxiv. } 262 . \\
3 & \text { Od. ii. } 74 . \\
4 & \text { Od. xiii. } 13 . \\
5 & \text { Od. xix. } 195 .
\end{array}
$$

${ }^{6} I l$. ix. 291. Cf. $1 l$. ix. 483. Peleus enriched Phoinix, and gave

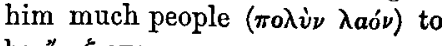
be aै ${ }^{\prime} \boldsymbol{\xi} \xi$ over. 
CHap. IV. accordance with the Ordinances of Manu, the king the chief appointed a chief of a town whose duty it was to of a town report to the higher officials on any 'evil arising in ceive the the town.' He likewise represented the king, and king's sup. had the king's right to receive supplies from those
plies. under his oversight.

'What food, drink, (and) fuel are to be daily given by the inhabitants of a town to the king let the head of a town take,'

the line always being drawn between legitimate demands and tyrannical extortion.

' For those servants appointed by the king for protection (are) mostly takers of the property of others (and) cheats; from them he (i.e. the king) should protect these people.' 2

The main- Under the rule of the Persians, all Asia was the Great parcelled out in such a way as to supply maintenance King, $\quad\left(\tau \rho \circ \phi^{\prime}\right)$ for the Great King and his host throughout the whole year. ${ }^{3}$ The satrap of Assyria kept at one time so great a number of Indian hounds, that four large villages of the plain were exempted from all other charges on condition of finding them food. ${ }^{4}$

and of

Solomon's table was provided after the same method.

'And Solomon had twelve officers over all Israel which provided victuals for the king and his household; each man his month in a year made provision,.... And Solomon's provision for one day was thirty measures of fine flour and threescore measures of meal, ten fat oxen and twenty oxen out of the pastures and an hundred sheep, beside harts, and roebucks, and fallowdeer, and fatted fowl .... And Solomon reigned over all kingdoms from the river unto the land of the Philistines, and unto the border of Egypt; they brought presents, and served Solomon all the days of his life. .... And those officers provided victual for king Solomon, and for all that came unto king Solomon's table, every man according to his charge.' 5

\begin{tabular}{|c|c|}
\hline $\begin{array}{l}1 \text { Manu, vii. } 118 . \\
2 \text { vii. } 123 . \\
3 \text { Herod. i. } 192 . \\
\text { Ibid. }\end{array}$ & $\begin{array}{l}5 \text { I Kings iv. } 7-27 \text {. One of } \\
\text { these officers was over 'threescore } \\
\text { great cities with walls and brazen } \\
\text { bars.' }\end{array}$ \\
\hline
\end{tabular}

Sesostris is said to have obtained his revenue Char. IV. from the holders of $\kappa \lambda \hat{\eta} \rho \circ \iota_{\text {in }}$ Egypt in proportion to Revenue the amount of land in each man's occupation $;^{1}$ and in ancient $_{\text {tand }}$ Pharaoh, having bought all the land at the time Egypt. of the famine in Egypt except that which supported the priests, took one-fifth of all the produce, leaving the remainder 'for seed of the field,' and for the food of the cultivators, and their households and little ones. 'And Joseph made it a law over the land of Egypt unto this day, that Pharaoh should have the fifth part, except the land of the priests only, which became not Pharaoh's.' 2

In this case Pharaoh became proprietor by purchase of the land in Egypt. But it must not be supposed that by exacting a payment from the occupier, the overlord as a rule had any power over the ownership of the soil. He no doubt had proprietary rights over his own estate, and may or may not have had power to regulate any further distribution of the waste. But the right of receiving dues, or of appointing another to receive them, gave him no power over the actual tillage of the soil.

The maintenance of the prince was a first charge Grants of apparently upon the property of his subjects; and land to it is easy to see how the lion's share would always $\underset{\text { made, }}{\text { easily }}$ be allotted to him, alike of booty as of acquired territory. As long as the community was pastoral, it is also easy to imagine how the chief both increased his own wealth and admitted favoured companions or resident strangers to a share in the elastic area of

${ }^{1}$ Herod. ii. $109 . \quad$ | ${ }^{2}$ Genes. xlvii. 26. 
Chap IV the common pasturage. After agriculture had in their assumed equal importance in the economy of the elastic tribe as the tending of flocks and herds, one is apt agri- to forget that for centuries-perhaps for thousands culture of years-the system of agriculture that grew up, still possessed much of the elasticity of the old pastoral methods. Under the open field system, such a custom as that described by Tacitus and in the Welsh Laws, viz. of ploughing up out of the pasture or waste sufficient to admit of each tribesman having his due allotment, and letting it lie waste again the next year, admitted of considerable readjustment to meet the exigencies of declining population, as well as providing an easy means whereby any stranger prince, like Bellerophon, who might be admitted to the tribe, could be allotted either a $\tau^{\prime} \mu_{e \varepsilon \nu o s}$ apart, or a $\kappa^{\lambda} \hat{\eta} \rho o s$ in the open plain.

Pindar describes this method of cultivation when he says :-

'Fruitful fields in turn now yield to man his yearly bread upon the plains, and now again they pause and gather back their strength.'

It is noticeable that the Aetolians offered Meleagros a $\tau \epsilon \dot{\epsilon} \mu \nu \nu$ s in the fattest part of the plain, wherever he might choose, as a gift ( $\delta \hat{\omega} \rho \circ \nu)$; and as the $\tau \epsilon \epsilon \in \nu o s$ would certainly be cultivated by slave or hired labour, what they really gave him was the right of receiving the produce from the 50 guai composing the rémevos. But this gift was meant as a special honour or bribe, and took a special form in being in land as a means of permanent enrichment.

1 Pind. Nem. vi. 11 (Trans. Myers), $f f$. Ridgeway, op. cit. p. 20.
In similar wise Ezekiel suggested the capitalisa- Crap. IV. tion, as it were, by a gift of land of the contributions and served to the princes, which no doubt were felt to be very other conirksome. In the division of the land, a portion was tributions. to be set aside first for the use of the temple and priests, then a portion for the prince.

'In the land shall be his possession in Israel, and my princes shall no more oppress my people; and the rest of the land shall they give to the house of Israel according to their tribes. Thus saith the Lord God, Let it suffice you, O princes of Israel ; remove violence and spoil and execute judgment and justice, and take away your exactions from my people, saith the Lord God.' 1

\section{And again :-}

'Moreover the prince shall not take of the people's inheritance by oppression, to thrust them out of their possession; but he shall give his sons inheritance out of his own possession; that my people be not scattered every man from his possession.' ${ }^{2}$

But there can be no doubt, that although the prince may have had no power to dislodge any of the free tribesmen of his own people from their holdings, yet no one could gainsay him if he chose to enrich himself by planting or reclaiming any part of his domains, as Laertes is represented as having done. ${ }^{3}$

The modern usage in Boeotia and in the island of Modern Euboea may very well represent the procedure of of the ancient times, and if it can be imagined that some of Greek method of the same sort was in vogue in Boeotia in methods. the time of Hesiod, it will be understood how possible it was for Hesiod's father to settle at Askra and gradually to acquire possession of a house and $\kappa \lambda \hat{\eta} \rho o s$.

\begin{tabular}{l|l}
1 & Ezekiel xlv. 8, 9. \\
2 & Ez. xlvi. 18.
\end{tabular}


Chap. IV. 'There is some cultivation from Plataea to Thebes, but strangely alternating with wilderness. We were told that the people have plenty of spare land, and not caring to labour for its artificial improvement, till a piece of ground once, and then let it lie fallow for a season or two. The natural richness of the Boeotian soil thus supplies them with ample crops. But it is strange to think how impossible it is, even in these rich and favoured plains, to induce a fuller population.'1

\section{At Achmetaga, in Euboea,}

'The folk pay for their houses a nominal rental of a bushel of wheat per annum, in order to secure the owner's proprietary claim, which would otherwise pass to the occupier by squatter's right after thirty years of unmolested occupation. They are at liberty to cultivate pretty well as much land as they care to, paying to the landlord one-third in kind. . . . The produce here is almost exclusively wheat or maize, but every family maintains a plot of vineyard for home consumption.' ${ }^{2}$

The gifts Whether the free tribesman ever looked upon the to the to the prince not food-rent for the ontribution he made to the maintenance of the princes, under whose protection he had the privilege of living, as a condition of tenure of his land, is open to doubt; but from the right to demand indiscriminate gifts, to confiscate or eject in case of refusal, it is only one step to the exaction of a regular food-rent as a return for the occupation of land.

\section{$\S 7$. SUMMARY OF THE EARLY EVIDENCE.}

IT may be useful here briefly to summarise the results of the inquiry of the last three sections into the relation of the ownership of land to the structure of society in Homer and in early times.

\footnotetext{
1 Mahaffy, Rambles in Greece, ${ }^{2}$ Rennell Rodd's Customs and 3rd ed. p. 200.
}

The princes had their compact estates divided off $\mathrm{CH}_{4 \mathrm{P}}$ IV. from the other land of the community, so that a The chief's passer-by by could point and say, 'There is the king's land apart

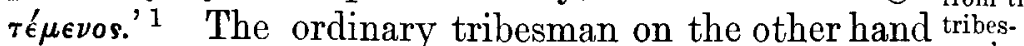
had a share in the common fields under cultivation, men's probably consisting of a number of scattered pieces of land lying mixed up with those of others, and therefore only referred to on the face of the land, under

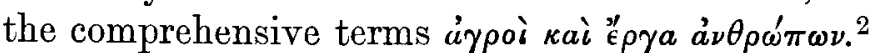

This share of the tribesman was, as in later times, called a $\kappa \lambda \hat{\eta} \rho \circ$ s, it being possible for a man to enjoy several such holdings and deserve the epithet $\pi o \lambda u ́ r \lambda \eta \rho o s$, whilst the lowest class of freemen consisted of those who possessed no land, under the ignominious title of $\boldsymbol{a}^{\prime} \kappa \lambda \eta p o s$.

The $\kappa \lambda \hat{\eta} \rho o s$, descending from father to son, was The land apparently connected with the oikos or household, the houseand supplied its maintenance. The oikos grew fat or holder in was consumed in accordance with the capacity of its to other head, and its continuity was regarded as a matter of the and utmost importance. Its members were bound together guests. at their ancestral hearth by mutual ties of common maintenance. The sanctity of thus sharing the same loaf extended also to guests, whose relations to their hosts might last for several generations. It is the necessity of supplying the oikos and its dependents with the means of sustenance and hospitality among a pastoral people gradually adapting themselves to agriculture, that regulates the tenure of land and the duties of the householder.

The power of the chieftain to draw upon the re- The chief

1 Od. vi. $293 . \quad$ । 2 Ib. 259.


Chap. IV sources of his people for the entertainment of his right to household and his guests by exactions payable in kind, demand supplemented by the power he also seems to have the possessed to transfer at will the right of receiving people; these 'gifts' to any one he chose, seems to contain the germs of the more complicated system of foodrents as a condition of land tenure, which is so important a feature of the Celtic tribal arrangements.

he had Inasmuch as the prince was a member of the tribe, tribal to a he was entitled to an allotment in the land under $\tau^{2} \dot{\epsilon} \in \nu$ os,
as the tribesman equal right of all members of the tribe to a share in to 2
$\kappa \lambda \hat{n} p o s$, the soil. But inasmuch as the prince possessed blood royal and claimed his descent from the very gods that the tribesmen worshipped, his dignity was above partaking with his tribesmen of a $\kappa \lambda \hat{\eta}$ pos in the common fields. He was therefore allotted a $\tau$ t' $\mu \epsilon \nu o s$ apart, and worthy of his divine parentage. Besides the bare single allotment of the $\tau \dot{\epsilon} \mu \epsilon \nu o s$, land was set apart for him as a gift of honour by the people, from whom honour and gifts to their prince were due. Gifts in land formed a special mark of honour, and may at the same time have served another purpose from the giver's point of view by way of a permanent source of income or endowment, as it were, whereby the continuous exactions towards the maintenance of the prince from the lands of the people might tend to be alleviated. Thus much of power over the property of his inferiors he undoubtedly retained, and he probably cultivated what he liked of the outlying lands under his sway.

but could But the evidence does not show that he ever had not de- the right of coming between the oikos of his tribes-

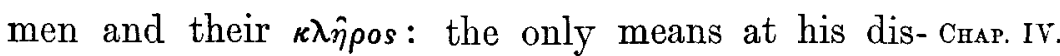
posal of severing the link between the family and the prive the land, were those employed by Ahab and Jezebel to of his acquire the 'inheritance' of the ancestral vineyard of land.

Naboth at Jezreel.

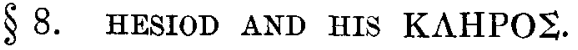

Is the time of Hesiod, the $\kappa \lambda \hat{\eta} \rho$ s $^{1}$ could be sold in case of need and added to the possession of another.

But the case of Hesiod is in itself somewhat Hesiod an exceptional. His father had fled from his own coun- grant: not try by stress of poverty, and settled on the barren a typical land of Askra in Boeotia, where he was allowed to family. acquire some land. ${ }^{2}$ He was therefore somewhat of a sojourner (the $\mu \in \tau a \nu a \sigma^{\prime} \eta \boldsymbol{s}$ of Homer), ${ }^{3}$ and, true to the Homeric doctrine, was unencumbered by the claims of kindred. Hesiod contrasts the ready help of the neighbour with the perfunctory slowness of the kinsman, duty-bound. The neighbour, he says, is prompted by the need of mutual protection of material property, the kinsman stays to bind on his sandals and gird his loins for the labour he is forbidden to shirk. ${ }^{4}$

Hesiod and his brother Perses had divided the $\kappa \lambda \hat{\eta} \rho{ }^{\prime}$ of their father into two, and lived apart. Perses had squandered his half, and spent his time

\footnotetext{
1 The $k \lambda \hat{\eta}$ oos is spoken of as admission to full civic rights. $V$. capable of good cultivation by supra, p. 97. means of a yoke of oxen.

2 Works and Days 637. Pos-
} 
Crap. IV. and his livelihood in the gay life of the town, but none the less seems to have expected to be allowed to draw still further on the resources of the paternal property, to the distress of his industrious brother.

Hesiod does not contemplate any possible means of making a living other than by tilling the soil; and his quaint ideas may be taken as typical of the small Boeotian peasant-farmer, allowance being made for the short time that his family had held land at Askra.

\section{\$ 9. SURVIVALS OF FAMILY LAND IN LATER TIMES.}

Land was IN later Greek writers it is several times stated that in theory the $\kappa \lambda \hat{r_{1}} \rho$ o from the all remark to what a deplorable extent the alienation
family. and accumulation of land into few hands had been carried. Aristotle comments on the excellence of the ancient law, at one time prevalent in many cities, against the sale of the original $\kappa \lambda \hat{\eta} \rho \circ$, and the good purpose therein of making every one cultivate his own moderate-sized holding. ${ }^{1}$

Innumerable passages could be quoted from the speeches of Isaeus, referring to the law that forbade any one to alienate by will his landed estate from his lawful sons. Plato warns his friends that buying and selling is desecration to the god-given $\kappa \lambda \hat{\eta} \rho$ s. $^{2}$

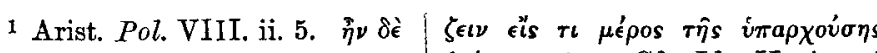

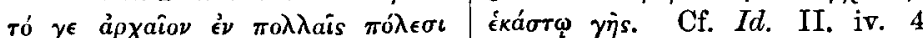

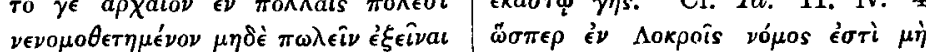

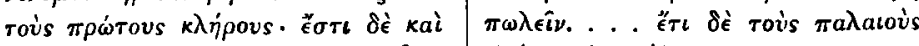

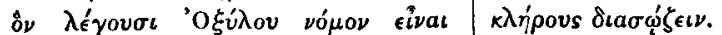

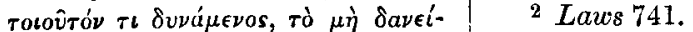

'Now I, as the legislator, regard you and your possessions, not CHap. IV. as belonging to yourselves, but as belonging to your whole family, both past and present.' 1

Plutarch and Heraclides say that the same law against the sale of the $\kappa \lambda \hat{\eta}$ pos existed anciently at Sparta.

Plutarch's evidence, late as it is, of the ancient In Sparta customs among the Spartans is worthy of further beacconsideration.

In his Life of Agis he states that the $\kappa \lambda \hat{\eta}$ oos tribesmen,

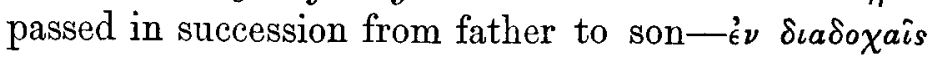

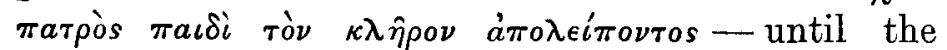
Peloponnesian war.

In his Life of Lycurgus he says that-

"When a child was born, the father was not entitled to main-

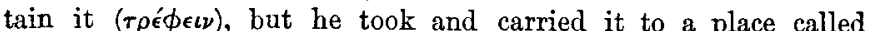
'lesche,' where the elders of his tribesmen were sitting, who, if they found the child pretty well grown and healthy, ordered its maintenance $(\tau \rho \epsilon \in \epsilon \epsilon \nu)$, allotting to it one of the 9,000 kleroi $(\kappa \lambda \eta \dot{\eta} \rho \omega \nu$

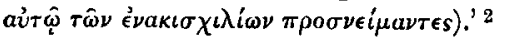

Elsewhere in Greece at the introduction of the new-born child to the relations and friends a few days after its birth, symbolical gifts of food were made as the child was carried round the hearth. ${ }^{3}$

The important part of this ceremony at Sparta, whodedescribed by Plutarch, seems to be the introduction to its as of the infant to the elders of the tribe, and the recog- mainte. nition by them of its right to maintenance, if it

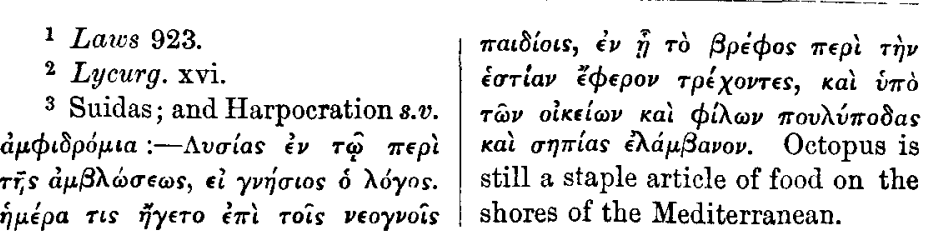


Chap IV appeared to them physically worthy of admission to the tribe. It cannot be supposed that Plutarch believed that vacant $\kappa \lambda \hat{\eta} \rho \circ$ escheated, so to speak, to the community, because he elsewhere describes the lamentable tendency of estates to get into few hands, which the community would in that case surely have been able somewhat to prevent. Nor is it likely that a $\kappa \lambda \hat{\eta} \rho o s$ was actually set apart for the maintenance of each infant, who was apparently still nourished in its father's house until seven years old, when its education and occupations were regulated by the State.

Reading this passage with the other in the Life of Agis, a natural inference is, that the child's right to succeed to the property of his father only was thereby assured to him by the elders, i.e. the right on his attaining manhood to enjoy the possession of land. This is the view taken by M. de Coulanges; ${ }^{1}$ but surely there is more underlying the account of the ceremony. What actually took place with regard to the allotment of a $\kappa \lambda \hat{\eta}$ oos to the infant member of the tribe, cannot be decided here. The State at Sparta undertook to educate all her sons after a certain age, and gave the parent no further rights over the child. Is there in this ceremony a transfer of the claim for maintenance from against the head of the household to the larger unit represented by the elders of the tribe, irrespective of the inheritance of the son from his father?

It would be necessary for the adult Spartan citizen, of the class of ómoco at any rate, to have a right to the produce of some land, as otherwise it is difficult to CHAp. Iv. see how he could contribute the necessary provisions that formed his share of maintenance at the joint table of his syssition; unless indeed he drew his allowance from his father's estate.

In any case the idea of the dependence of a Maintenmember of the tribe for sustenance upon his right ance to a $\kappa \lambda \hat{\eta}$ pos is striking; and at the same time the ${ }_{\kappa \lambda \hat{\eta} \rho o s}^{\text {from the }}$ evidence goes to show that his maintenance was a claim upon a group of kinsmen at Sparta, comprising more than the nearest relations, and was recognised as such by them.

The link that bound the cultivators to their land The family was so strong in early times at Athens, that mort- bound to gages could apparently not be paid off by mere atAthens; transfer of the land itself; but the whole family of the debtor went with their mortgaged property and became enslaved to the creditor, having in future to work the land for him at a fixed charge.

This was the state of affairs that Solon set himself to mend, and it is instructive that the method, he seems to have chosen, was to loosen the tie between the owner and his land, and, by facilitating the transfer of land from one to another, to obviate the necessity of taking the debtor's person with his family into slavery on account of the debt. ${ }^{1}$

Nevertheless, in spite of the radical legislation of Solon, the sentiment that bound the family to the soil remained long after his time.

Besides the prohibition to sell the family land and in which Aristotle speaks of as prevailing in Lokris, the Lokris. 
Chap. IV. Hypoknemidian Lokrians insisted on actual residence on that land in the case of their colony at Naupaktos. Though unable apparently wholly to forbid the participation of the colonists in the ancestral rites of their kin in Lokris, they took advantage of the prevailing sentiment with regard to the permanence of the family, and insisted that the continuance of the hearth of the colonist at Naupaktos should at any rate be considered of equal importance.

According to an inscription of the fifth century B.c. :-

'The colonist has the right to return to Lokris and sacrifice

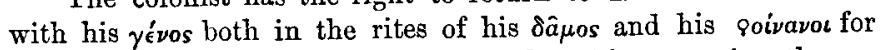
ever. He can only return permanently without paying the reestablishment tax if he has left $\dot{e} \nu \tau a \mathfrak{i}$ ioria at Naupaktos a grownup son or a brother. If a $\gamma^{\prime}{ }^{\prime} \nu o s$ of the colonists is left without a

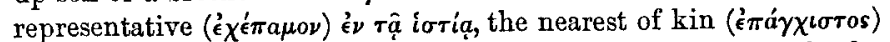
in Lokris shall take the property, provided he go himself, be he man or boy, within three months to Naupaktos. A colonist can inherit his share of his Lokrian father's or brother's property. ...'

'If a magistrate deals unfairly and refuses justice, he shall be

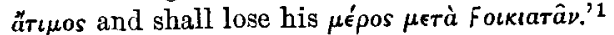

But heirs Though the sale of estates could be effected at at Athens Athens in the fourth century B.C., yet, when the also must owner died without having sold, the succession

was regulated by the ancient custom. If there were legitimate children, the inheritance to the land could not be diverted from them, even by will ; ${ }^{2}$ provided only that the children had gone through the ceremony of being accepted and enrolled by the phratria. If the descendant had neglected this formality, and had failed to be recognised as a legal member of the kin-

\footnotetext{
1 Dareste, \&c., Recueil des
Inscr. Jurid. Gr. xi.
}

dred or clan, he or she lost all rights to the property, Crap. IV. which went to the devisee or next of kin. ${ }^{1}$ The right to possess land was thus at Athens, as at Sparta, intimately connected with the tribal organisation; and the claim for maintenance from the paternal estate could only lie, after full acknowledgment of the necessary qualification had been granted by the larger unit of relationship.

\section{$\S 10$. THE IDEA OF FAMILY LAND APPLIED ALSO TO LEASEHOLD AND SEMI-SERVILE TENURE.}

Atrention has been drawn to the reciprocal rela- Further tions that existed between the family and its land, applicaand their inseparability in the minds and phraseology idea of of the Greeks at different times. There is a further land. development however arising from this point of view, without some notice of which the subject of the tenure of the $\kappa \lambda \hat{\eta} \rho o$ would be incomplete, and which serves to confirm the method with which this subject has been treated.

Though alike in their estimation of the possession of land as a means of livelihood and for the accumulation of wealth, the Greeks had very different views with respect to the place of agriculture as a worthy occupation for a citizen. Sparta regarded it as entirely beneath the dignity of her sons and forbade their personal application to the cultivation of their $\kappa \lambda \hat{\eta}$ poc. There was at Athens, on the other hand, a large class of citizens whose energies were entirely devoted to the production of fruits of the earth, whilst

1 Isaeus, iii. 73 and 80. 
Chap. IV. the life of a country gentleman, combined with that of the farmer, was by no means despicable in their eyes.

Two There were mainly two methods of enjoying the methods of
occupation possession of a landed estate. Either the land was of land: cultivated by the owner himself with the help of (1) by bought slaves or hired servants, few or many, as dehimself;
(2) by (2) by subject
populapopula or the owner resided in the city or a neighbouring town, and the land was tilled by aliens or serfs (called sometimes $\kappa \lambda a \rho \hat{\omega} \tau a \iota)$, like the Helots of Sparta, who paid an annual contribution from the produce to their landlord. The serf was often attached hereditarily to the soil in the sense of being unable to give up his holding, but also had certain rights as against his master, both in the matter of his own possessions and in that he could not be sold out of the country. ${ }^{2}$

At Gortyn There is a passage in the Gortyn Laws that on extinc- states:- - that if there are no rightful successors to citizen-
family the family the household's $\kappa \lambda$ ápos, i.e. the persons composing it, inherited. shall inherit his property. That is to say, if a Gortynian family died out and no legal representative could be found, their proprietary rights were extin- -

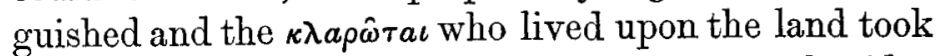
all their property. This provision favours the idea

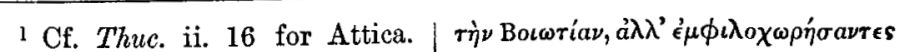

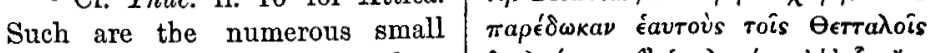

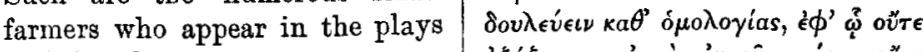
of Aristophanes.

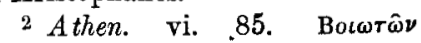

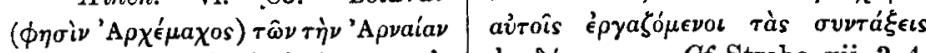

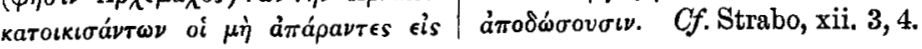

that at Gortyn also the citizen-population came of a CHap. IV. race of conquerors, who were not exactly looked upon as ground landlords upon whose land a subject family was settled or had been allowed to remain, but that, whilst the relation of the $\kappa \lambda a \rho \hat{\omega} \tau a \iota$ to their land was of the closest if not an absolute bondage to the soil, the proprietary rights of their superiors and masters consisted of the conqueror's overlordship and the power to derive their maintenance from the joint produce of their serfs' labour and the land. ${ }^{1}$

This comprehensive use of the word $\kappa \lambda \hat{\eta} \rho o s$, as meaning both the allotment of land and the family who were bound to occupy it, whose labour also created its value to its lord and master, is quite consistent with the use of the word in reference to the holdings of the Spartan citizens. The allotment of a $\kappa \lambda \hat{\eta}$ pos at Sparta evidently meant also a transference of rights over the Helots that worked it; and even if this further implication was not actually included in the meaning of the word, it was so inseparable in thought that no explanation was necessary of the composite significance of the allotment.

The Athenians in their $\kappa \lambda \eta p o v \chi^{\prime a} a \iota$ seem instinctively Similar to have combined these two methods of agriculture. twonure in The $\kappa \lambda \eta \rho o v$ o of a new city, but they remained citizens of Athens, $\kappa_{\lambda \text { npov- }}$ holding however their $\kappa \lambda \hat{\eta} \rho \circ$ in a remote district. ${ }^{\text {íal. }}$

\footnotetext{
1 Gortyn. v. 25. ai $\delta \dot{\epsilon} \mu \grave{\eta} \epsilon i \epsilon \nu$ rather than with the preceding

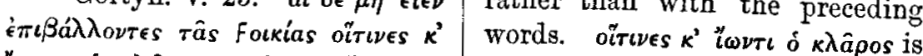

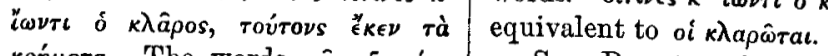

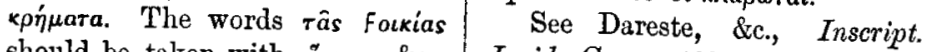
should be taken with oitrives, \&c., $\mid$ Jurid. Gr. p. 463.
} 
Crap IV. But the chief feature of this method of landholding was that the owner, though remaining a citizen of Athens and liable to the same claims from the mother city in respect of military service, \&c., as before, was yet supposed to reside in the neighbourhood of his new $\kappa \lambda \hat{n}$ os. This was the case, even when the land itself was left in the hands of the conquered population at a fixed annual charge.

Examples An inscription found on the Acropolis of Athens, in Salamis, and relating to some date about 560 or 570 B.C., defines the legal status of the first $\kappa \lambda \eta \rho \circ \hat{v} \chi \circ$ sent to Salamis. They were assimilated to Athenian citizens as to taxes and military service; but they must reside on their land under pain of an absentee's tax to the State. ${ }^{1}$

in Lesbos, In the year 427 B.c. the Athenians conquered the island of Lesbos. They imposed no tribute on the subjugated islanders, but, making the land into three thousand $\kappa \lambda \hat{\eta} \rho \iota^{\prime}$ ' except the Methymnian land,' they first set apart three hundred $\kappa \lambda \hat{\eta} \rho \circ$ as sacred to the gods, and on to the others they sent off $\kappa \lambda \eta \rho \circ \hat{v}-$ xoc chosen by lot from themselves; to these the Lesbians paid annually for each $\kappa \lambda \hat{\eta}$ pos two minae, and themselves worked the land. ${ }^{2}$

in Euboea. According to the account of Aelian, the same method of procedure was adopted after the conquest of Euboea in about 510 B.C. The Athenians, having conquered the Chalkidians, apportioned their land to $\kappa \lambda \eta \rho \circ \hat{v} \chi \circ \iota^{3}$ in two thousand $\kappa \lambda \hat{n} \rho \circ$, i.e. the country

\begin{tabular}{|c|c|}
\hline $\begin{array}{l}{ }^{1} \text { Mittheil. Inst. Ath. ix. p. } \\
\text { 117. The original number of } \\
{ }_{\alpha} \lambda \text { pov } \chi \text { ot in this case was ap- } \\
\text { parently five hundred. }\end{array}$ & 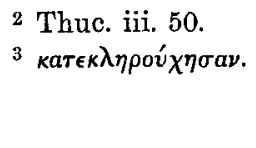 \\
\hline
\end{tabular}

called Hippobotos ; and, setting aside $\tau \epsilon \mu \mu^{\prime} \nu \eta$ to Athena Crap. IV. in the place called Lelantos, they let out ${ }^{1}$ the rest according to the pillars that stand in the King's Stoa, which thus bear record of the leases. ${ }^{2}$

The holding of each $\kappa \lambda \eta p o v$ os may have varied Each in size according to the character of the soil and ${ }^{\kappa \lambda \hat{\eta} \rho o s}$ features of the country; but it may safely be supported asserted that it must have been of sufficient dimen- families. sions, not only to provide subsistence for the native population left on the soil, but also to pay a considerable portion towards the keep of the $\kappa \lambda \eta \rho o v y o s$ himself, during his enforced residence in the conquered country.

The class of citizen from amongst whom the $\kappa \lambda \eta$ pov̀ $0 \iota$ were chosen by lot, did not consist of families with much property in Athens. ${ }^{3}$ Younger sons without occupation, whom their fathers had not been quite callous enough to 'expose' in infancy, ${ }^{4}$ and restless individuals without property in the mother country, would be most likely to offer themselves. And to such the two minae per annum, paid by the Lesbians from the produce of each $\kappa \lambda \hat{\eta}$ pos, would appear a reasonable if not a sumptuous provision of livelihood. There were a hundred drachmae in the mina, and if it is true, as asserted by Plutarch, ${ }^{5}$ that in the time of Solon one drachma was the price of a sheep, a yearly income of two hundred sheep, or their equivalent, would be forthcoming to each

\begin{tabular}{|c|c|}
\hline 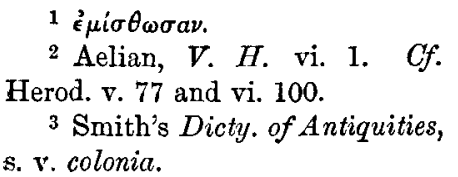 & $\begin{array}{l}{ }^{4} \text { Bekker, Charicles, p. } 218 . \\
5 \text { Ridgeway, Origin of Currency. } \\
\text { kc., p. } 324 .\end{array}$ \\
\hline
\end{tabular}


Chap. IV. $\kappa \lambda \eta \rho o v \chi$ os - surely a considerable contribution to the maintenance of his family. ${ }^{1}$

Under these circumstances each $\kappa \lambda \dot{\eta} \rho o s$ served to provide maintenance for two households-both of whom had hereditary rights therein, though themselves in different strata of society. Both households also were in a sort attached to the soil, the one in practical bondage, the other bound by law to reside in the country wherein lay its substance, and (if we may use the common expression of the Welsh Laws) its privilege.

The same This double and continuous ownership was not double ownership confined to the semi-servile tenure of lands annexed in leases , by Athenian conquests.

Leases to be handed down from father to son for ever-тòv mávтa xpóvoy-subject of course to the regular payment of the rent, seem to have been quite usual.

What is said to be the oldest Greek contract we have, is of this nature. ${ }^{2}$ It was found in Elis at Olympia, and runs as follows:-

'Contract with Theron and Aichmanor with regard to the land in Salamona of eighteen plethra. Rent, twenty-two manasioi of barley in the month Alphioios; if he omits, let them pay double. They shall hold for ever.' 3

There is an instance of a proprietor of land at Mylasa, in Karia, deliberately selling his estates to a

\begin{tabular}{|c|c|}
\hline $\begin{array}{l}1 \text { The ordinary Athenian di- } \\
\text { cast is supposed to have subsisted } \\
\text { largely upon his pay of three } \\
\text { obols or a half-drachma per } \\
\text { diem. } \\
2 \text { Dareste, \&c., Recueil Inscr. } \\
\text { Grec. p. } 256 \text { 'siii.). }\end{array}$ & 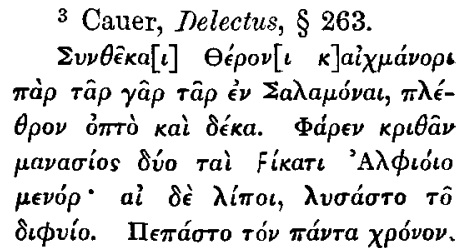 \\
\hline
\end{tabular}

sacred community for the benefit of the god, and Chap. IV. receiving them again (like the Roman precaria) from

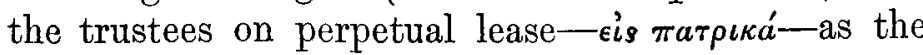
patrimonial substance of his family, for himself and his issue or whosoever should take inheritance from him. He thus obtained a money value down in return for his property, but bound himself and his descendants to an annual rent of so many drachmae, to form part of the revenues of the god. Moreover his 'family-land' in this case was apparently more inalienable now than before; for he might neither divide the land henceforth, nor share the responsibility for the rent with another. ${ }^{1}$

1 Dareste, \&c., Inscr. Jurid. Grec. xiii. quater. (Mylasa in Karia. Second century B.c.) summarised:-

A. The tribe $\left(\phi v \lambda \eta^{\prime}\right)$ of the Otorkondeis at the advice of their treasurers and led by the priest of Artemis, decide to purchase from Thraseas, son of Polites son of Melas of Grab ... and adopted son of Heracleitos son of Heracleides of Ogonda, lands ( $\gamma$ '́as) in the Ombian plain with the sixty-two ranks of vines, three olive trees, and all the other trees without reserve, also lands elsewhere with the trees without reserve for 5,000 drachmae of light Rhodian silver, provided that Thraseas has the sale registered with sureties. Moreover, Thraseas coming to the ekklesia declared that he was ready to manage these things: and the sale having taken place of the said (properties) to the trustees in the name of the god, Thraseas him- self then and there took on lease all the said (properties) from the treasurers of the tribe: and he shall hold them ( $\epsilon$ is narpıká) for his patrimony, himself and his issue or those to whomsoever the inheritance of his goods passes, and he shall pay annually to the treasurers of the tribe 100 and . . drachmae, without fail or fraud.

B. . . all the land and trees which Thraseas has bought from Artemisia, daughter of Hekataios of Ketambissos, without exception in these places either in the matter of the share he took in the division with his brother or of what he bought from Artemisia, all for 7,000 drachmae of light silve of Rhodes, provided that Thraseas register the sale and give sureties, And coming before the ekklesia Thraseas declared that he was prepared to manage this ; and the sale of the foregoing having taken place to the trustees in the name 
Chap. IV. Do not these instances show that even leases were Perhaps included in the same category with actual ownership due to the of land, being embraced within the characteristic idea idea of the that the land that contributed to the maintenance of family as a the family and had come to be regarded almost as
continu. the ing unit. giving that family its social if not its political status, should descend unintermittently from generation to generation in that family, though its occupation was subject to providing support likewise to a superior owner and his family, whose descendants in their turn also would demand their share in the produce?

Is the conclusion justified that the basis of this indomitable feeling was that the peculiar view of the family, as consisting of a long line of past and future representatives, precluded the individual, who happened to be the living representative at any given time, from taking an irresponsible position as absolute master of the property, upon which his family had been, was, and would be dependent?

of the god, Thraseas himself then and there took on lease all the foregoing from the treasurers of the tribe : and he shall hold them (eis marpexá) for his patrimony, himself and his issue or those to whom the inheritance passes, and he shall pay annually to the treasurers of the tribe 300 drachmae.
The rent forms part of the revenues of the god. If Thraseas gets more than two years in arrear, the contract is annulled.

He shall not divide the land or share the rent (ov $\pi a \rho a \chi \omega \rho \eta \dot{\sigma} \sigma \epsilon$ \&

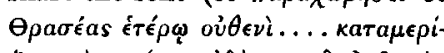

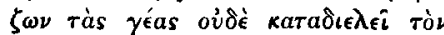
фópov).

\section{CHAPTER V.}

\section{CONCLUSION}

IN weighing the results of this essay, it Chap. v. would be absurd to pretend that anything of the No final nature of a last word can be said on the subject. word can The process of the early development of Greek said. society cannot be ascertained merely from the study of a few survivals in historic times. The comparative method must be carried much further than has been attempted here, before the secrets of antiquity can be laid bare and an authoritative statement made.

There would seem, however, to be at any rate some points, of those that have come under notice, worthy of further investigation, in so far as they indicate that Greek society was no isolated growth, but must be given a place in the general development of the systems of Europe.

It is suggested that in the continuity of city life Explanafrom an earlier stage of society under some form of tion of the the Tribal System, can be found the only natural of the explanation of the structure of the kindred at Athens be found in the fourth and fifth centuries B.c. Comparison in seent of 
Crap. v. with the customs of other nations,-the Hindoos, the city life Welsh, and the Israelites, the last two being the most from typical examples of peoples of which we have written earlier stage of tribal society. records whilst still living under the tribal systemhas shown remarkable analogies in the organisation of their inner society.

Similarity The actual similarity in the sentiment which surbetween
the bond rounded the possession of the privileges of tribal of tribal blood and the title to citizenship at Athens, can

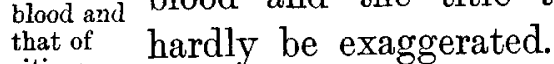

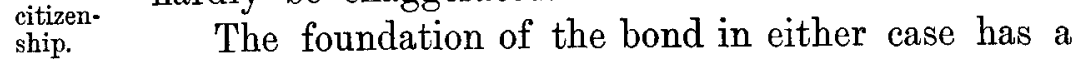
The three- threefold aspect. The bond is one of blood, of bold :- religion, and of maintenance.

(1) the The qualification for citizenship, as much as for bond of the tribal privilege, was a question of parentage;
blood and the citizen equally inherited, with his blood, responsibilities towards the community into which he was born, as to a larger kindred.

(2) the Membership of the tribe or of the city was the bond of only qualification, that admitted to the privilege and duty of partaking in the public religious observances. Tribesmen and eitizens, by virtue of their privilege, shared in the worship of the greater gods, of Hestia in the Prytaneum, of Zeus Agoraios, and of the Heroes or special guardians of their community; in like manner as the member of the smaller group of a kindred, by virtue of his blood, shared in the worship of the Apollo Patroïos, the Zeus Herkeios or Ktesios, and the heroes or ancestors of his family. Inasmuch as citizenship depended upon purity of descent, the possession of the latter qualification carried with it the right to share in the greater ceremonies. But the converse was equally stringent, in that the possession of shrines of Apollo Patroïos Cнат. v. and Zeus Herkeios was impossible, unless the family was one of those who had for many generations been recognised as belonging to the true stock of the community.

Inasmuch as the worship of private or public (3) the gods consisted mainly of offerings of food, of beasts maintenor produce of the earth, and wine, every tribesman ${ }^{\text {ance. }}$ or citizen must have had the means of providing his share in the offerings, besides supporting himself and his family. Those devoted to handicraft or merchandise were often despised by the regular tribesman or citizen, and sometimes therefore formed separate clans by themselves, like the smiths in Arabia. It is not surprising, therefore, to find that the membership of the tribe or city should have carried with it the right to the possession of some portion of the arable land and of the pasture, upon which all were regarded as being dependent. In this way the possession of land was intimately related to the status and the duties of the owner. It was the visible mark of his full tribal privilege, and was the practical means of his fulfilling his duty towards his fellows and the public religion, as well as to the needs of his ancestors and household. It seems also to have been believed that, in partaking of the hospitality or sharing in the sacrificial feast of any family, a bond was for the time being created which was in most respects practically equivalent to relationship by blood to the members of that family. ${ }^{1}$

\footnotetext{
1 Robertson Smith (The Reli- | maintain this imaginary kinship gion of the Semites) holds that the between the deity and the wor object of sacrifice was thus to 1 shippers.
} 
Crap. V. Apart from the tribal character of the qualification Many for citizenship, the most conservative organisation tribal wherein had been stereotyped the most precious of tribal customs, was that of the kindred.

It is suggested that the vitality of the customs and the household. surrounding the bond of family relationship was due to the importance attached to the religious and social functions incumbent on all members of a household united by kindred blood. The actions of the individual members were constrained by their weighty responsibilities towards the continuance and prosperity of the composite household, in which they moved, and apart from which their existence could not but be altogether incomplete.

The worship of ancestors occupied a prominent place in the needs of the Athenian household, and, no doubt, had a corresponding influence in the preservation of its unity. The same of course cannot be said for Wales, where Christianity had replaced, in the records at any rate, whatever religious beliefs may have existed earlier. But the grouping of the kindred according to grades of relationship was adhered to by the Welsh as an intrinsic part of their very conception of a kindred; and this would point to the conclusion that such subdivisions were due to wider needs than can be found in any particular form of religious belief or worship.

But these If, as has been suggested, in adhering to these survivals
mostly found in of their tribal ancestors, how is it that the most Homeric convincing evidence comes from as late as the fifth records. and fourth centuries B.c. and mainly from the most highly civilised of the cities of Greece?
The Iliad and the Odyssey may perhaps be Chap. v. trusted as truly portraying, so far as they go, the manners and customs of the great period of Achaian civilisation, known as Mycenean, which may be said to have culminated just before the Dorian invasion. Whence then came the public recognition of those household ceremonies of ancestor-worship, which filled such a large place in the life of the Athenian citizen, and which, it has been suggested, were consciously or unconsciously slurred over by the Homeric poets?

Mr. Walter Leaf has already found an answer to They perthis question, ${ }^{1}$ viz. that these ceremonies were the haps belong cherished customs of the ancient Ionian or the prePelasgian inhabitants of Greece, who had formed the inhabisubstratum of society under Achaian rule, and who Greece. only came into prominence on the removal of their superiors at the time of the Dorian invasion. And this continuity, underlying the superficial rule of the Achaians, seems to be borne out by recent research and discovery. ${ }^{2}$

The Athenians always boasted their Ionian descent, and may well have inherited their habits with the traditions of their origin.

But the customs reviewed in the foregoing Butmany

\footnotetext{
1 Companion to the Iliad, pp. | worship : that, ancestors being 6-7.

2 Since the foregoing chapters were in print, I have had the benefit of seeing Herr Erwin Rohde's admirable work, entitled Psyche (Freiburg and Leipsig, 1894). His view is that the worship of Heroes had the complete form of ancestorfamily tomb on private ground, death made no break in the membership of the family. And he claims that the Seelencult or ancestor-worship of the later Greeks must have been continuous from pre-Homeric times.
} 
Crap. $\mathbf{v}$. pages seem to have a wider parentage than were can be attributed to the Pelasgians alone. Spar-

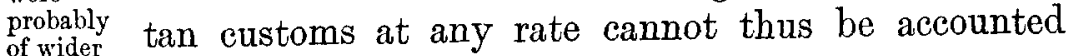
parentage. for.

Compari- In the course of argument reference has often son with been made to the Jewish records in the Books of the of the Old Testament, and indeed a remarkable parallel is presented in the history of the two peoples. Both peoples apparently reached their greatest period about the same time. The reign of Solomon with its gold and costly workmanship must have resembled that of the Mycenean kings in more than similarity of date, and outward splendour. Taking Homer again as the courtly chronicler of the Achaian age of gold, the Books of the Kings of both peoples are curiously conscious of their former tribal conditions, through which they easily trace back to the very fountain-head of their race.

Reaction In the period of the decay of the Jewish people in times of
distress to under the stress of invasion by foreign kings, strenuearlier ous efforts were made by their prophet leaders to tribal haits by purge them from the alien blood and alien influences the Jews, contracted in the careless days of their prosperity. Their aim was to restore once more those strict tribal habits which had served them so well at the time of their own victorious invasion, and which still lay dorand per- mant in their constitution. In similar wise, the period hapes by of Achaian prosperity seems to have been followed by Achaians. a rise into prominence at any rate, if not an actual resuscitation, of old tribal customs.

The actual traces of tribal institutions in Homer These need not be underrated. There is much that is of a tions to his tribesmen and to their gods. Survivals Chap. V. of tribal custom may also be seen in the reverence only for the guest, and the sacredness of the bond of dormant hospitality lasting as it did for generations; and in out and the blood-feud with its deadly consequences, especially all Greeks, when occurring within the tribe or kindred. Indeed if only the Pentateuch of the Achaians could be found in the ruins of Mycenae and added to the Homeric Book of the Kings, would it not then probably be evident that there was much more of a tribal nature in the organisation of the kindreds of the Achaians and surviving throughout the whole period of their splendour than the aristocratic poets of the Homeric schools allowed themselves to record?

Although therefore nearly all our evidence of the if not pracinternal structure of the kindred among the Greeks tically dates from the fifth century B.c., the ar $\chi_{\llcorner\sigma \tau \in i a}$ at tribal Athens must not be put down as belonging merely to that period. In the light of the close analogies to be found in the structure of other tribal systems, it is probable that such subdivisions of the kindred belong to an extremely early period in the history of the Greeks, whether as Achaians or Ionians or Dorians. Are they not indeed necessary features of tribal society itself wherever it is examined? 


\section{N D E X}

Adoption, object of, 35 ; out of unfortunate home, 36 ; ceremony of 36-7

Agora, 2, 3

á $\gamma \chi \iota \sigma \tau \epsilon i a, 32$; its meaning, 55 ; its limits, 58-9; all within it liable for bloodshed, 75 et seg. $;$ its tribal origin, 143

Ancestor - worship, 10, 140 ; in Homer, 5, 7; in Israel, 8, 9 ; in Egypt, 11 ; pre-Homeric, 141,$$
\text { in }
$$

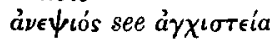

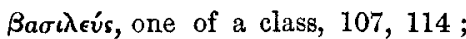
honoured like a god, 105-6, 122 ;

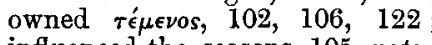
influenced the seasons, 105 , note; over-lordship not altogether hereditary, 107 ; levied maintenance on their people, 115 122 ; Solomon, 116 ; household

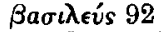

Bastard, no place in family, 95-6 allotment or gift for his maintenance, $95-6$

Blood, as basis of family, 13 ; of tribe, \&c., 4-5, 138 ; its purity jealously guarded, 67 et seq.; acquisition of, 68 et seq.

Blood-fine, not within the tribe or kindred, 42-4, 77 ; in Wales, the galanas, 78 et seq. ; paid by whole family, 79 et seq.
Bloodshed, responsibility for, 42 ; rested on áy ${ }^{\prime} \iota \sigma \tau \epsilon i a, 75$ et seq. ; within the kindred, 44, 77

$$
\text { C }
$$

Citizenship, admission to, 71,96 qualification for, by three descents, 73 ; basis of, 138 ; confirmed to son of stranger, 71, note

\section{$\mathbf{E}$}

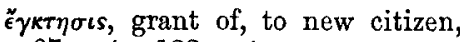
97 , note ; 123, note

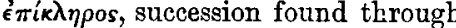
her, 23 ; she must marry next-ofkin, 23-7; in Gortyn laws, 26 ; where more than one 26 ; in herited for her issue, 28 ; inas, 31,34 ; had right of maintenance from property, 23-4

\section{F}

Family (see oikos), bound to the land, 127 et seq.; family estate in Santa Maura, 86 ; head of family, 91

Funeral, see Sacrifices

GaveIKIND, in Kent, 95 Guest, importance at sacrifice, 99100 ; hereditary guestship, 110 
Hearth, 3, 4; as basis of the family, 13, 17; in Prytaneum, 4, 15 ; initiation of heir to, 89

Heir, duties of, 18-19, 20 ; importance of male heir, 21-3, 98 et seq. daughter's son, 23-7; always ranks as son of deceased, 34 et seq.e 59 et seq.; ; inithed to kindred, 36 ; and to the deme, 38-9 importance of introduction of, 41, 125-8; co-heir in Wales, 51 ; law of succession, 57 et seq. ; disinheritance, 61 ; division among heirs, 64 et seq.' 101 ; Ahab's 'inheritance' of Naboth's vineesiod, his of a farmer, 109

Hestia, 3, 4, 138 ; called 'princess,' 13

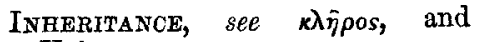
Heir

KINSHIP, grades of, 48 et seq. ; in India, 52 ; in Wales, 49, 67 et seq. ; the fourth degree, 73, ninth, 68 seventh, 78 et seq.; the ninth, 68 et seq.; wife's relations no kin to husband but are to son, 61 , note

Kinsmen, duties of, 18,42 ; next of kin marries 'heiress,' 23-7, 35; his duty to redeem property in Israel, 32, 95; kinsmen accept heir, 36, 41, 125-7 ; sanction disinheritance, 61 ; liable for bloodshed, 75 et seq. ; Hesiod's idea of, 123

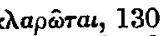

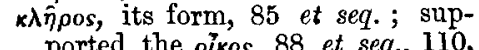
ported the oikos, 88 et seq., 110, $89,93,97$; no joint holding between father and sons, 93 ; sold in case of need, 94 ; in theory in- alienable, $94,113,124,127$; allotted to new citizen, 96 ; in Homer, 102 ; held by tribesmen, 108 ; of Hesiod, 123

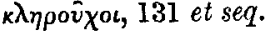

LAND, ownership of, proof of civic rights, 83, 96 (see $k \lambda \hat{\eta} \hat{\rho}$ os and TÉ $\mu \in$ Nos)

$L a r=$ 'Iord,' 12 ; lares of king, 4

Leases, for ever, 134-6

rate, not in Greece, 27; in

India, 29 ; in Israel, 30 et seq.

\section{M}

Matntenance of parents (see Parents); of oikos, 110 ; the bond of, 110,139 ; of the chief, 114 et seq. 122 ; in Ezekiel, 119 ; of children at Sparta, 125; gift of food to babe, 125 ; derived from $k \lambda \hat{\eta} \rho o s$, 127

Manes, duties to, in India, 19

Marriage, of heiress, 23-6 ; of near relations, 29; of pidow (see Levirate)

\section{O}

Octopus, 125 note

oíkos, part of yévos, 17 ; importance of continuity of, $9,19-20$ $30,35,111,128$; the unit of ownership of property, 47, 109 . ownership of property, the householder in India, 99 ; supported by its land, 110, 113, 121 ; of Bouseits land, 55,63 ; power of head of, 10s, 5

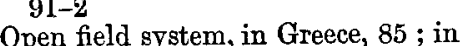
the islands, 87; in Homer, 88 , 104 ; its elasticity, 118-9

Parage, in Normandy, an undivided tenure, 50
Parents, maintenance of, 18,48 after death, 19

Phratria, enrols legitimate sons, 36-7; partly responsible for bloodshed, 76

Primogeniture, not the rule in Greece, 90; nor in rule in et seg. ; eldest on hadia, 97 rights or dignity 90 certain et seq. et seq. ; called $\eta \theta \in i o s, 91$, note
Prytaneum, 3, 4, 15, 138

REGISTER, of phratria, 36 ; of deme,

Ruth, as widow and $\dot{\epsilon} \pi \dot{i} \boldsymbol{\lambda} \lambda \rho \circ$ s, 31-4

\section{$\mathrm{S}$}

SACRIFICES, object of, 6,139 , note ; to the dead, 8, 9-12; of funeral cake in India, 51 et seq.; funeral rites at Athens, 20; of householder in India, 99; bond of common religion, $13,53,138$
Stranger, abhorrence of, $5,71,74$; as guest, 99 (see Guest); admission to tribe, 67 et seq., 96

Té $\mu \epsilon \nu o s$, in Homer, 103, 113 ; allotted to princes and gods, 102, 106, 118,

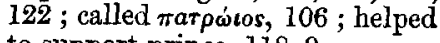
to support prince, $118-$

Tonsure, in Greece, 39 ; in India, 40

Tribe, its basis one of blood, 4-5, 138; possible development of, 14-15; admission to, 68 et seq., 96 (and see Citizenship)

WIDow, could not inherit from husband, 27-8; returned to her kin or guardian, 28 ; when allowed to remain, 28, note; the case of Tamar, 30 ; of Ruth, 31 et seq.

THE END. 